
of Engineers $S_{\circledast}$

Engineer Research and

Development Center

\title{
Full-Scale Accelerated Testing of Multi-axial Geogrid Stabilized Flexible Pavements
}

W. Jeremy Robinson, Jeb S. Tingle, and Gregory J. Norwood

June 2017

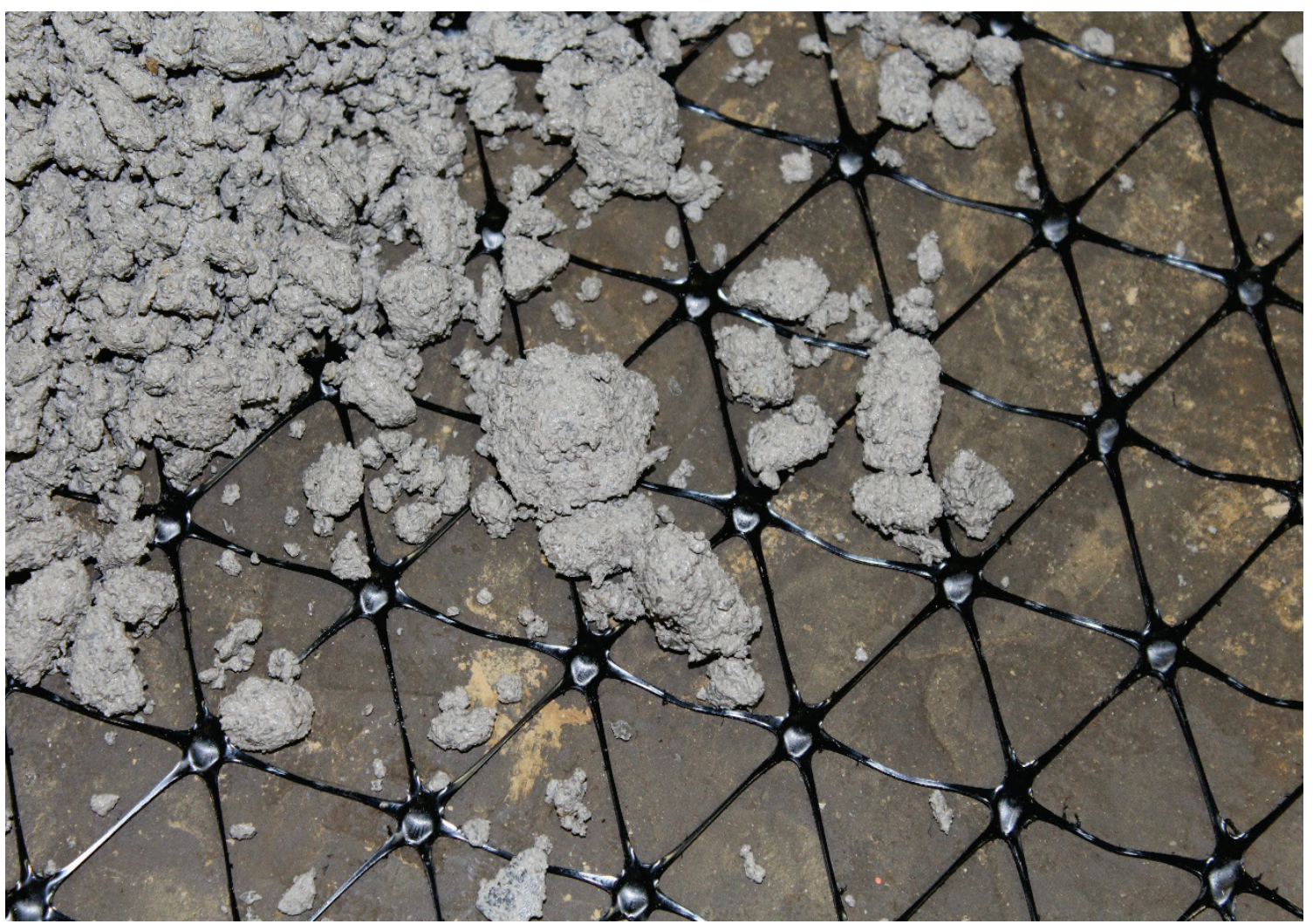


The U.S. Army Engineer Research and Development Center (ERDC) solves the nation's toughest engineering and environmental challenges. ERDC develops innovative solutions in civil and military engineering, geospatial sciences, water resources, and environmental sciences for the Army, the Department of Defense, civilian agencies, and our nation's public good. Find out more at www.erdc.usace.army.mil.

To search for other technical reports published by ERDC, visit the ERDC online library at http://acwc.sdp.sirsi.net/client/default. 


\title{
Full-Scale Accelerated Testing of Multi-axial Geogrid Stabilized Flexible Pavements
}

W. Jeremy Robinson, P.E., Jeb S. Tingle, and Gregory J. Norwood, P.E.

Geotechnical and Structures Laboratory

U.S. Army Engineer Research and Development Center

3909 Halls Ferry Road

Vicksburg, MS 39180-6199

Final report

Approved for public release; distribution is unlimited.

\author{
Prepared for Tensar International Corporation \\ 2500 Northwinds Pkwy \#500 \\ Alpharetta, GA 30009 \\ Under Project Number 151098
}




\section{Abstract}

The U.S. Army Engineer Research and Development Center (ERDC) constructed a full-scale test section to evaluate the performance of geogridstabilized highway pavements. The test section consisted of two pavements composed of 3 in. of hot mix asphalt over a crushed limestone base course over a 6 CBR subgrade. One section was stabilized with Tensar's TX 5 multiaxial geogrid, and the second section was stabilized with a developmental geogrid referred to as TX8. Each section was instrumented with moisture probes, pore-water pressure probes, temperature probes, earth pressure cells, and asphalt strain gauges. Simulated truck traffic was applied using a heavy vehicle simulator (HVS) to evaluate the rutting performance and collect instrumentation response data. This report summarizes the material characterization and construction techniques, instrumentation response, and performance response of each section under simulated truck traffic. Comparisons are drawn to previous sections constructed and trafficked at ERDC without geogrids utilizing similar construction techniques and material properties.

DISCLAIMER: The contents of this report are not to be used for advertising, publication, or promotional purposes. Citation of trade names does not constitute an official endorsement or approval of the use of such commercial products. All product names and trademarks cited are the property of their respective owners. The findings of this report are not to be construed as an official Department of the Army position unless so designated by other authorized documents. 


\section{Contents}

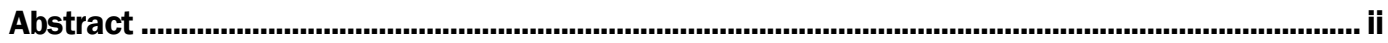

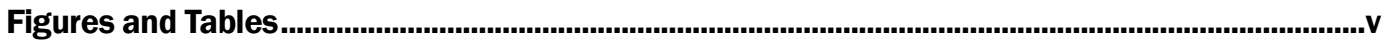

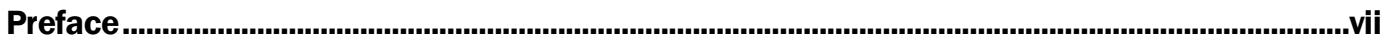

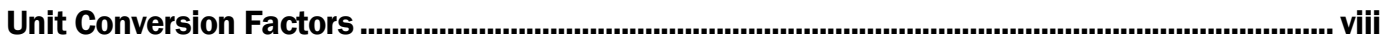

1 Introduction .............................................................................................................................. 1

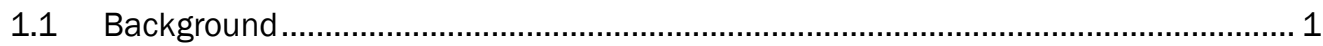

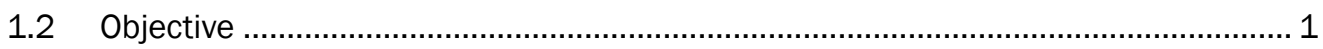

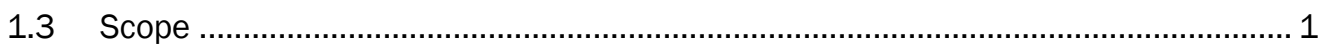

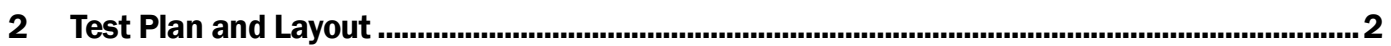

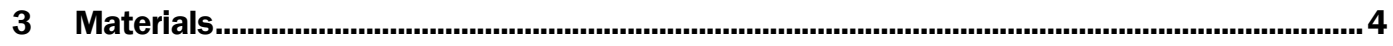

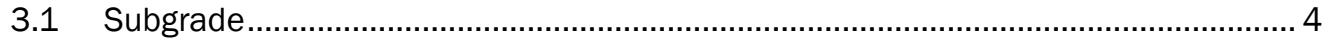

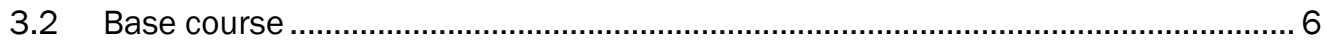

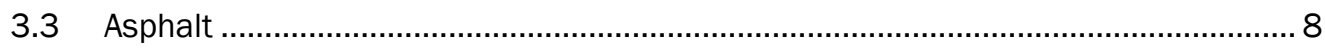

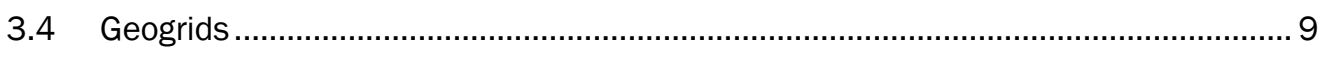

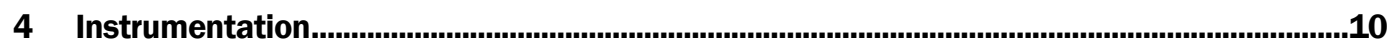

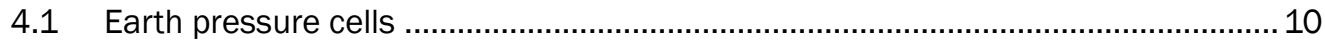

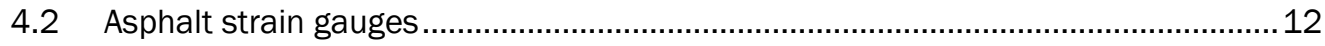

4.3 Single-depth deflectometer............................................................................. 13

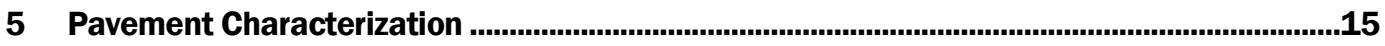

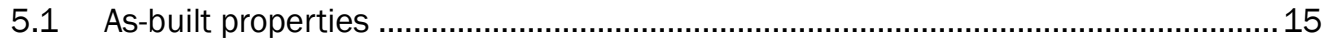

5.2 Dynamic cone penetrometer............................................................................ 16

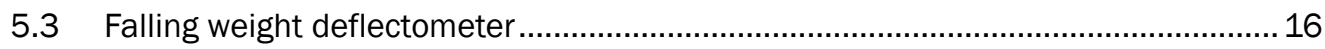

6 Traffic Testing

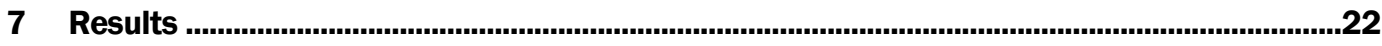

7.1 Surface deformations....................................................................................... 22

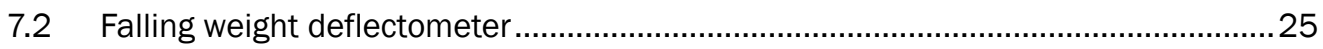

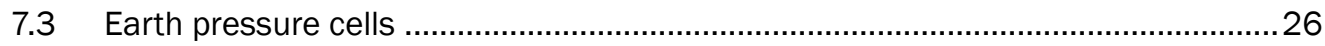

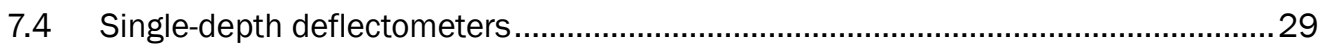

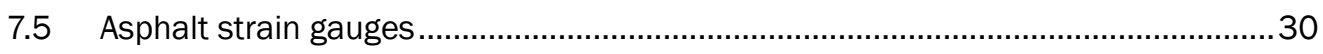

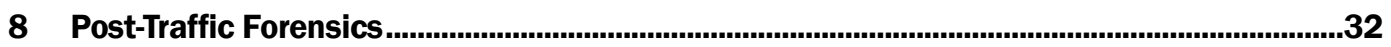

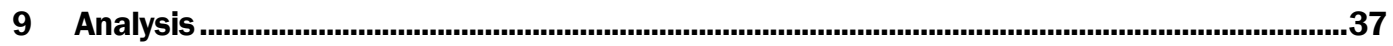

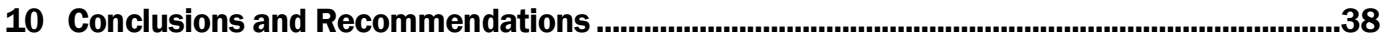




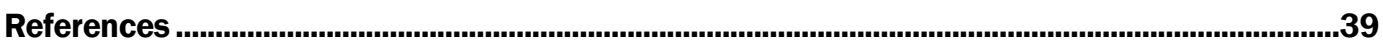

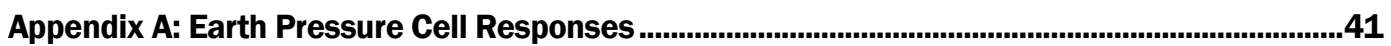

Appendix B: Single-Depth Deflectometer Responses ...............................................................57

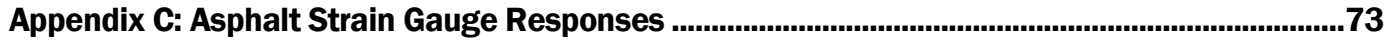

Report Documentation Page 


\section{Figures and Tables}

\section{Figures}

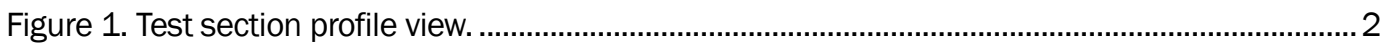

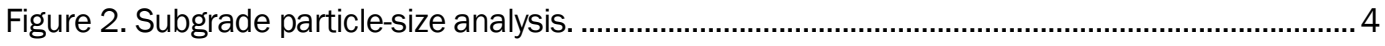

Figure 3. Clay subgrade moisture-density relationship......................................................................

Figure 4. Clay subgrade $\mathrm{CBR}$ /moisture content relationship. ......................................................... 6

Figure 5. Crushed limestone base particle-size analysis......................................................................

Figure 6. Limestone base moisture/density relationship.................................................................

Figure 7. Plan view of instrumentation layout. ...................................................................................10

Figure 8. Profile view of instrumentation layout..........................................................................11

Figure 9. Earth pressure cell installation in subgrade. ……................................................................11

Figure 10. Asphalt strain gauge adhered to crushed stone base. .....................................................12

Figure 11. Asphalt strain gauge covered with HMA prior to paving....................................................13

Figure 12. Single-depth deflectometer installation. .........................................................................14

Figure 13. As-built DCP results for Item 1 Station 25, West. ...........................................................17

Figure 14. As-built DCP results for Item 2 Station 25, East................................................................18

Figure 15. As-built ISM values. ...............................................................................................19

Figure 16. Dual-wheel tandem axle configuration..........................................................................20

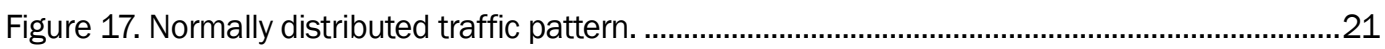

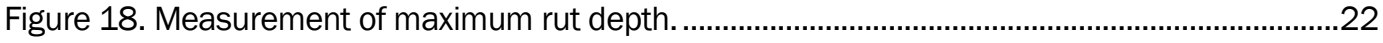

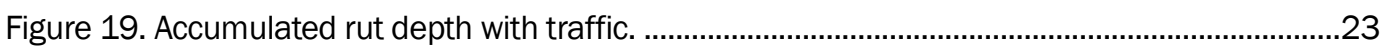

Figure 20. Permanent surface deformation with traffic. .................................................................24

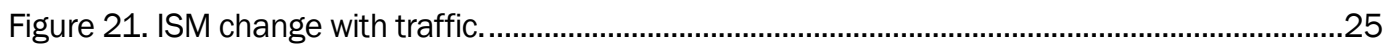

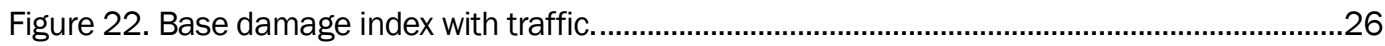

Figure 23. Peak subgrade earth pressure cell response during trafficking. …….............................28

Figure 24. Peak base earth pressure cell response during trafficking.............................................29

Figure 25. Peak subgrade deflection during trafficking. .....................................................................30

Figure 26. Peak asphalt tensile strain during trafficking...................................................................31

Figure 27. Item 1 excavated geogrid....................................................................................................33

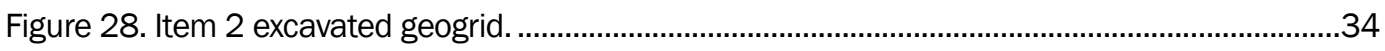

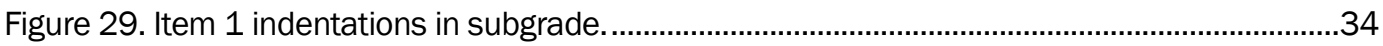

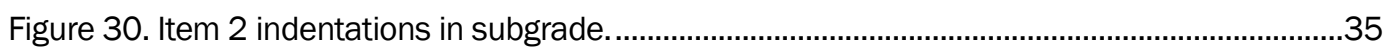

Figure 31. Post-traffic pavement cross section in Item 1. ............................................................35

Figure 32. Post-traffic pavement cross section in Item 2 ..............................................................36

Figure 33. Post-traffic pavement cross section in unstabilized section. ............................................36 


\section{Tables}

Table 1. Hot-mix asphalt properties........................................................................................ 8

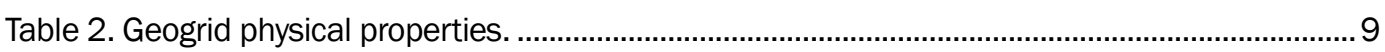

Table 3. As-built section properties............................................................................................15

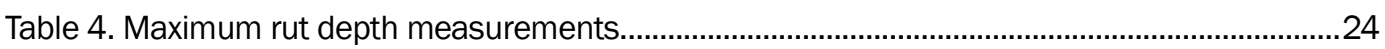

Table 5. Permanent surface deformation measurements.............................................................2

Table 6. Predicted and measured earth pressure cell responses. ……...............................................2

Table 7. Predicted and measured single-depth deflectometer responses.........................................29

Table 8. Predicted and measured asphalt strain gauge responses. …...............................................31

Table 9. Post-traffic physical data...............................................................................................32

Table 10. Effective stabilized layer structural coefficient. .................................................................37 


\section{Preface}

This study was conducted for Tensar International Corporation located at Alpharetta, Georgia. Dr. Mark H. Wayne, Tensar, provided technical guidance and review during the project. Mr. Jeb S. Tingle was the ERDC program manager.

The work described in this report was performed by the Airfields and Pavements Branch (GMA) of the Engineering Systems and Materials Division (GM), U.S. Army Engineer Research and Development Center, Geotechnical and Structures Laboratory (ERDC-GSL). At the time of publication, Dr. Timothy W. Rushing was Chief, CEERD-GMA; Dr. Gordon W. McMahon was Chief, CEERD-GM; and Ms. Pamela G. Kinnebrew, CEERD-GZT, was Technical Director for Military Engineering. The Deputy Director of ERDC-GSL was Dr. William P. Grogan, and the Director was Mr. Bartley P. Durst.

COL Bryan S. Green was the Commander of ERDC, and Dr. David W. Pittman was the Director. 


\section{Unit Conversion Factors}

\begin{tabular}{|c|c|c|}
\hline Multiply & By & To Obtain \\
\hline cubic feet & 0.02831685 & cubic meters \\
\hline cubic inches & $1.6387064 \mathrm{E}-05$ & cubic meters \\
\hline cubic yards & 0.7645549 & cubic meters \\
\hline degrees Fahrenheit & $(F-32) / 1.8$ & degrees Celsius \\
\hline feet & 0.3048 & meters \\
\hline gallons (U.S. liquid) & 3.785412 E-03 & cubic meters \\
\hline inches & 0.0254 & meters \\
\hline miles per hour & 0.44704 & meters per second \\
\hline mils & 0.0254 & millimeters \\
\hline pounds (force) & 4.448222 & newtons \\
\hline pounds (force) per foot & 14.59390 & newtons per meter \\
\hline pounds (force) per inch & 175.1268 & newtons per meter \\
\hline pounds (force) per square foot & 47.88026 & pascals \\
\hline pounds (force) per square inch & 6.894757 & kilopascals \\
\hline pounds (mass) & 0.45359237 & kilograms \\
\hline pounds (mass) per cubic foot & 16.01846 & kilograms per cubic meter \\
\hline pounds (mass) per cubic inch & $2.757990 \mathrm{E}+04$ & kilograms per cubic meter \\
\hline pounds (mass) per square foot & 4.882428 & kilograms per square meter \\
\hline pounds (mass) per square yard & 0.542492 & kilograms per square meter \\
\hline square feet & 0.09290304 & square meters \\
\hline square inches & 6.4516 E-04 & square meters \\
\hline tons (force) & $8,896.443$ & newtons \\
\hline tons (force) per square foot & 95.76052 & kilopascals \\
\hline yards & 0.9144 & meters \\
\hline
\end{tabular}




\section{Introduction}

\subsection{Background}

With increased material costs and reduced budgets, transportation officials are often tasked with applying innovative solutions to pavement design and construction projects. The inclusion of geosynthetics in pavement structures has been utilized as a means of reducing costs and/or extending pavement service life. These products have been shown to be effective in overcoming challenging subsurface conditions, in reducing overall pavement thickness, and in reducing labor and equipment requirements. As new geosynthetic products are developed, full-scale performance data are needed to provide quantifiable benefits to pavement designers.

\subsection{Objective}

The objective of this effort was to construct and traffic full-scale flexible pavement sections to provide performance data for comparing the effectiveness of Tensar's multi-axial geogrids to an unstabilized flexible pavement section. The test items constructed were similar to previously tested unstabilized and stabilized flexible pavement sections allowing for performance comparisons. A secondary objective was to record pavement response data for the verification of mechanistic performance models for Tensar's geogrid stabilization products currently on the market and for the validation of the SpectraPave4Pro ${ }^{\mathrm{TM}}$ software used to design the test items.

\subsection{Scope}

The scope of this project included the construction and trafficking of a fullscale test section comprised of a geogrid-stabilized base course. The U.S. Army Engineer Research and Development Center (ERDC) constructed the full-scale test section as designed by Tensar under shelter in its Hangar 2 Pavement Test Facility. During construction, quality control data were collected to verify layer properties and to ensure that the project objectives were accomplished. The test items were trafficked with ERDC's Heavy Vehicle Simulator (HVS). Pavement performance data were collected at selected intervals during trafficking for use in comparing the performance of the test items with the geogrid-stabilized base course to the historical test item with an unstabilized base course. In addition, instrumentation response data were collected and reported to support the verification of mechanistic pavement performance models. 


\section{Test Plan and Layout}

The structural design of the test section was developed by Tensar Corporation. The test items were constructed utilizing similar materials and construction techniques as previous unstabilized and stabilized sections (Norwood and Tingle 2014) to extend the usefulness of performance comparisons. A profile view of the stabilized and unstabilized test section (Norwood and Tingle 2014) is shown in Figure 1. Each test item consisted of a 10 -ft-wide by 50 -ft-long testing area. For this study, two test items were constructed with each item stabilized with a different multi-axial geogrid. Item 1 was stabilized with $\mathrm{TX}_{5}$ multi-axial geogrid, and Item 2 was stabilized with a developmental grid identified as TX8. The TX5 multi-axial geogrid was previously tested but due to a temperature control malfunction in the HVS, temperatures rose outside the established control range and the section was reconstructed and retested. The subgrade for the test items was constructed with nominal 36 in. of high-plasticity clay $(\mathrm{CH})$ placed to achieve the target California Bearing Ratio (CBR) value of $6 \%$. A CBR of $6 \%$ was selected to provide a test section with moderate subgrade strength. The 6-in.-thick aggregate base course consisted of a crushed limestone, stabilized by placing a multi-axial geogrid at the base-subgrade interface. The test-section surface consisted of a 3-in.-thick hot mix asphalt (HMA) layer. All construction and traffic testing occurred under ERDC's Hangar 2 pavement testing facility, minimizing the potential for moisture variations due to environmental factors.

Figure 1. Test section profile view.

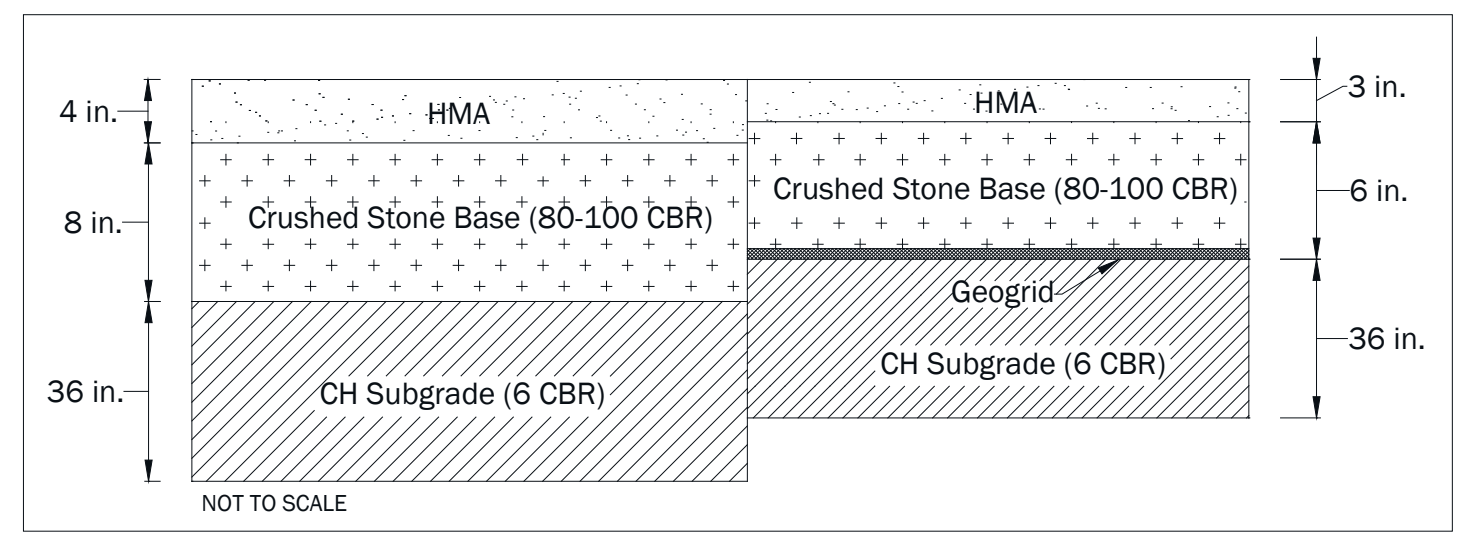


The structural design of the test section was developed by Tensar Corporation following the guidelines set forth in the American Association of State Highway and Transportation Officials (AASHTO) 1993 design guide (AASHTO 1993) and their SpectraPave4Pro ${ }^{\mathrm{TM}}$ software. The geogrid-stabilized items were assigned a structural number of 2.92 with an estimated service life of 580 ,000 equivalent single axle loads (ESALs).

The test items contained a suite of instrumentation consisting of asphalt strain gauges, earth pressure cells, single-depth deflectometers, moisture probes, pore-water pressure transducers, and temperature probes.

The test item was trafficked with ERDC's Heavy Vehicle Simulator (HVS) simulating normal highway loadings. The configuration used for testing consisted of a tandem-axle dual wheel gear loaded to a nominal load of $20,000 \mathrm{lb}$. Tire pressures were maintained at $120 \mathrm{psi}$ throughout testing. The equivalent axle load factor for this configuration is 2.08. Therefore, one pass of the HVS was equal to 2.08 equivalent standard axle loads (ESALs).

The traffic loading was applied at a target test chamber temperature of $77^{\circ}$ Fahrenheit, with an allowable temperature range of $72-82^{\circ}$ Fahrenheit. The HVS is equipped with automated software that halts traffic and alerts the operator if the temperature falls outside the prescribed range. 


\section{Materials}

Laboratory tests were performed to characterize each component layer material. The material characterization results are presented in the following paragraphs.

\subsection{Subgrade}

A locally sourced high-plasticity clay was used to construct the nominal 36in.-thick test-section subgrade. A particle size analysis, shown in Figure 2, indicated the material consisted of $96.8 \%$ fines passing the No. 200 sieve. The soil had a liquid limit (LL) of $65 \%$, a plastic limit (PL) of $27 \%$, and a plasticity index (PI) of $37 \%$, as determined by ASTM D4318. According to the Unified Soil Classification System (USCS), the soil was classified as a high-plasticity clay $(\mathrm{CH})$ and an A-7-6 according to the American Association of State and Highway Transportation Officials (AASHTO) classification system.

Figure 2. Subgrade particle-size analysis.

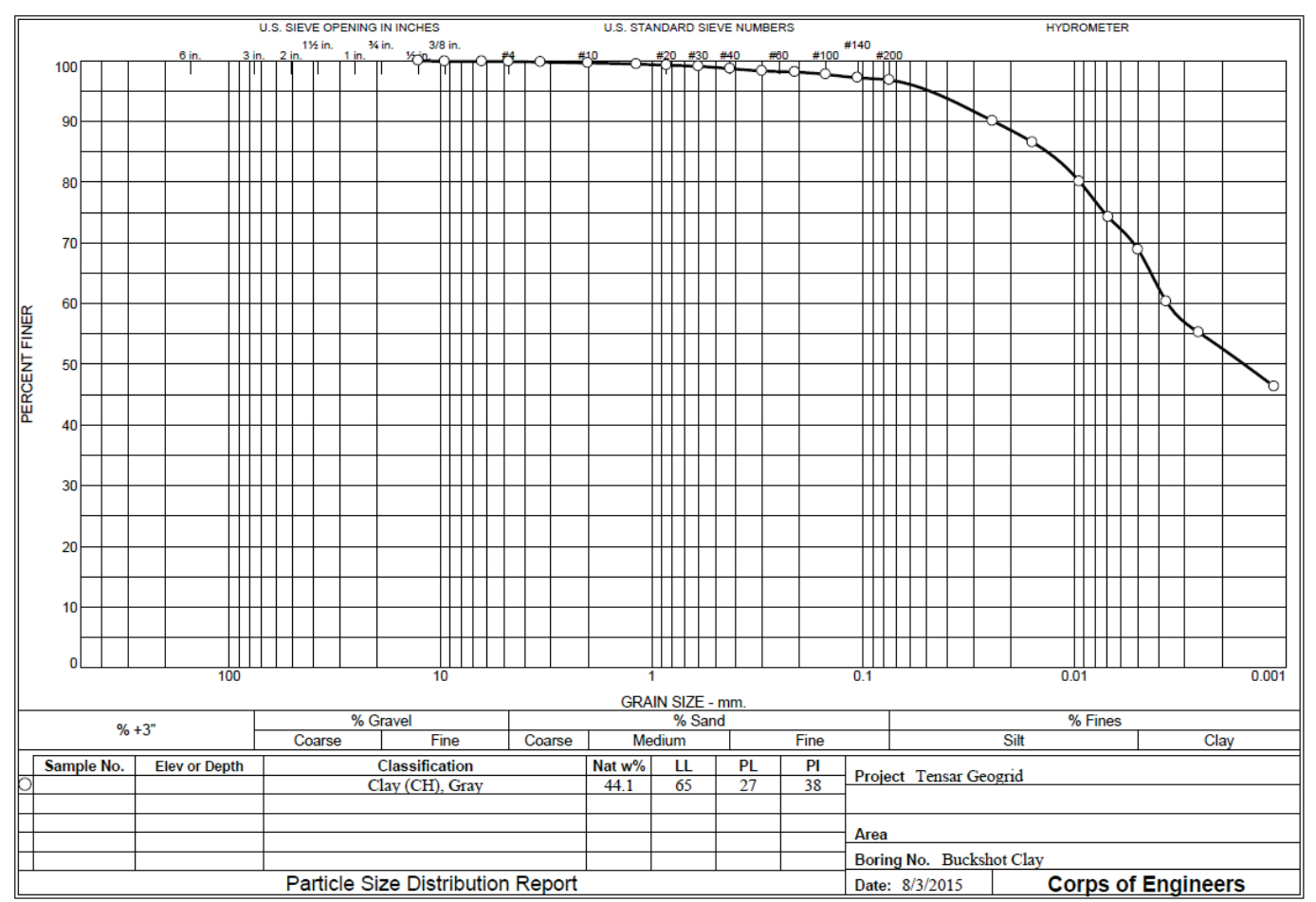


Modified proctor compaction tests (ASTM D1557) were performed to determine the relationship between moisture content and dry density. Maximum dry density was found to be $101.8 \mathrm{pcf}$ at an optimum moisture content of $18.6 \%$. Graphical results of the moisture-density relationship test are shown in Figure 3.

Figure 3. Clay subgrade moisture-density relationship.

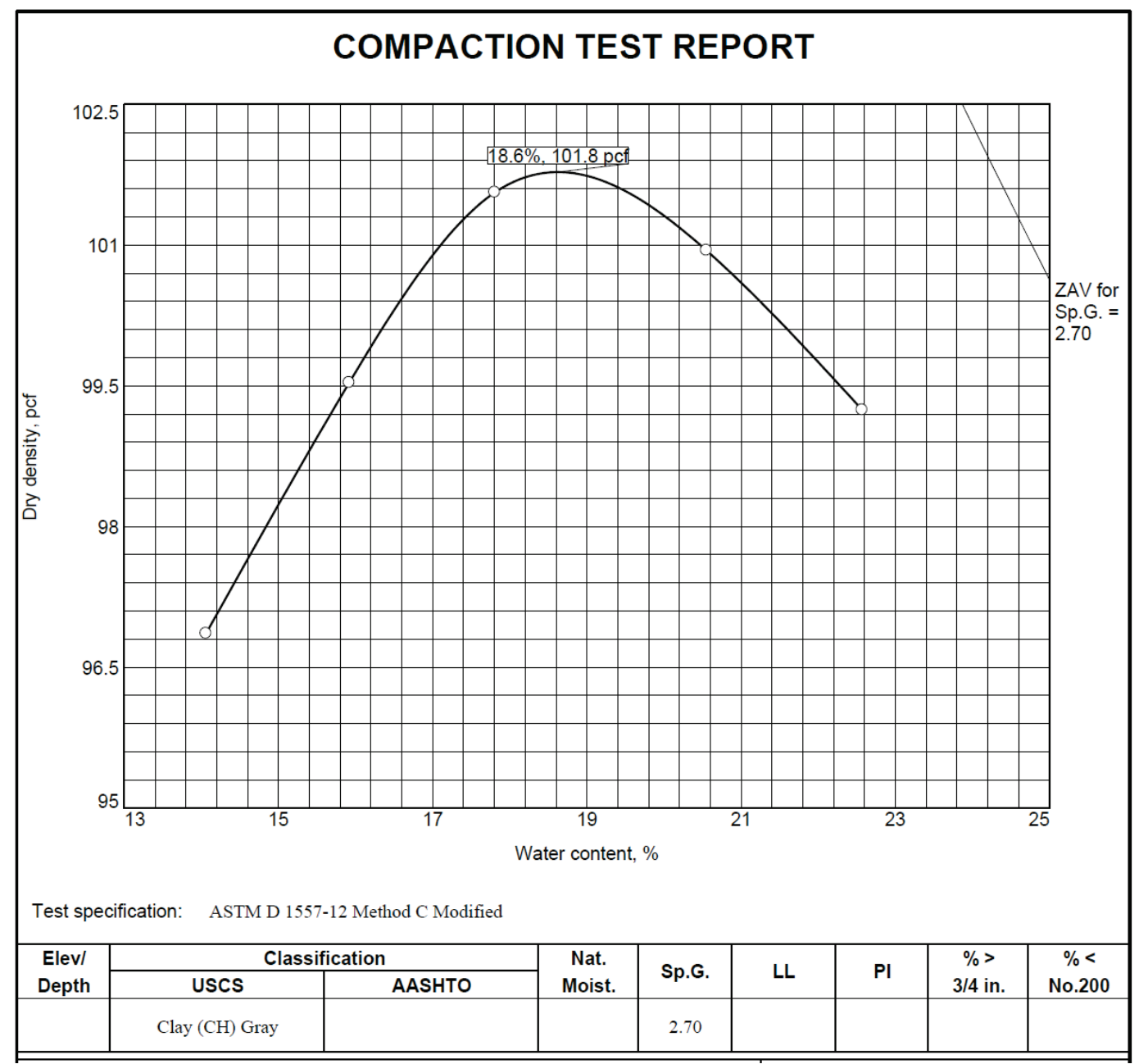

To determine an in-place moisture content at the targeted $6 \mathrm{CBR}$, a suite of laboratory CBR tests (ASTM D1883) were performed. These tests were conducted at moisture contents ranging from approximately $17 \%$ to approximately $40 \%$. A target in-place moisture content of $33 \%$ was selected based upon the relationship between moisture content and CBR. The relationship between CBR and moisture content is presented graphically in Figure 4. 
Figure 4. Clay subgrade $\mathrm{CBR/moisture} \mathrm{content} \mathrm{relationship.}$

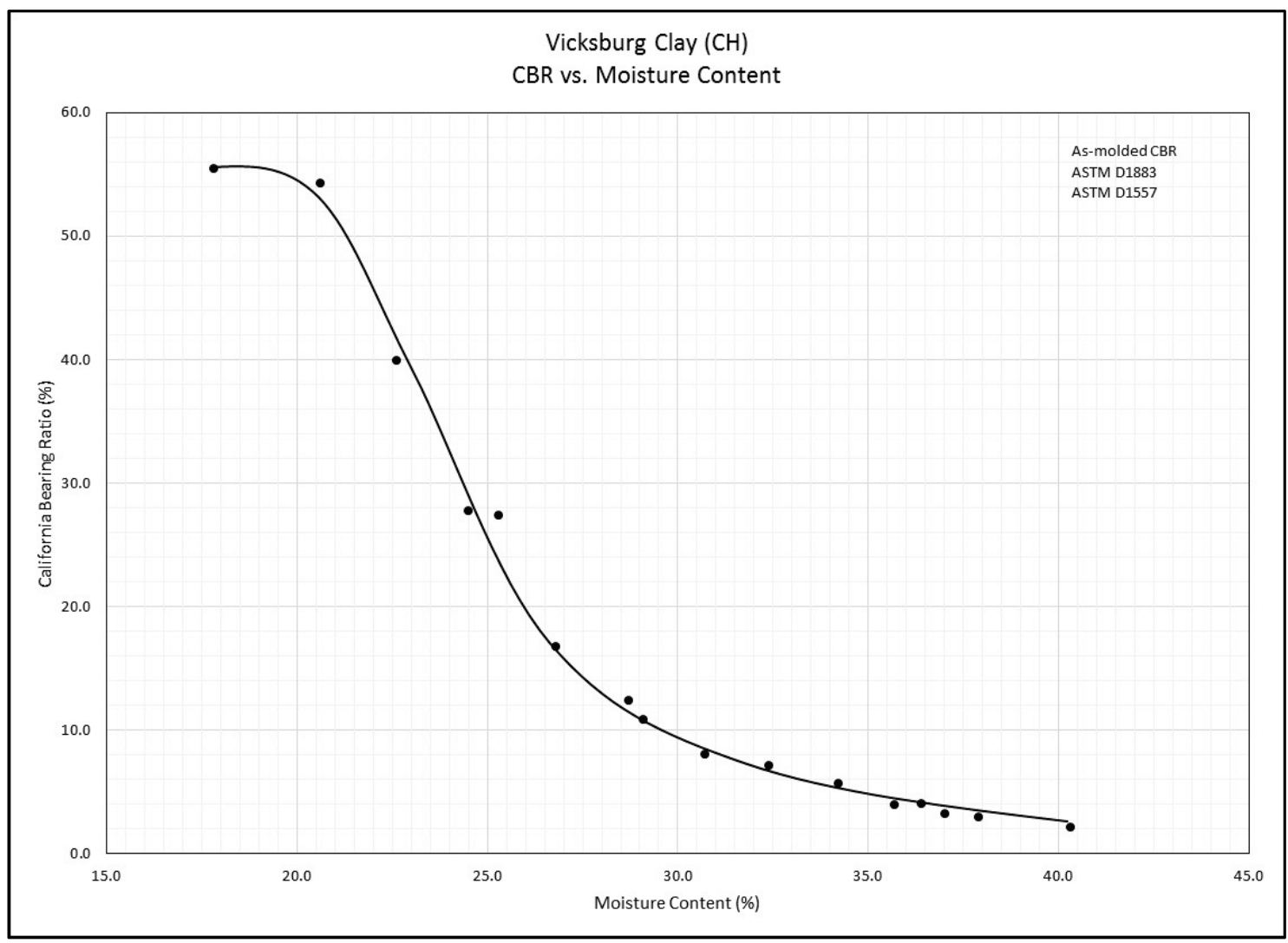

\subsection{Base course}

Locally available crushed limestone was used to construct the flexible aggregate base course. The gradation for the crushed limestone is shown in Figure 5. ASTM procedure D2487 was used to determine that the base course was comprised of $71.5 \%$ gravel, $23.3 \%$ sand, and $5.2 \%$ non-plastic fines passing the No. 200 sieve. The coefficient of curvature (Cc) was calculated as 2.71, and the coefficient of uniformity $(\mathrm{Cu})$ was 21.16 . The crushed limestone aggregate base was classified as a well-graded gravel with silt and sand (GW-GM) according to the USCS and an A-1-a according to the AASHTO procedure. Modified proctor compaction tests (Figure 6) were performed in accordance with ASTM D1557 Method C Modified. The maximum dry density was $146.7 \mathrm{pcf}$ at an optimum moisture content of $5.9 \%$. 
Figure 5. Crushed limestone base particle-size analysis.

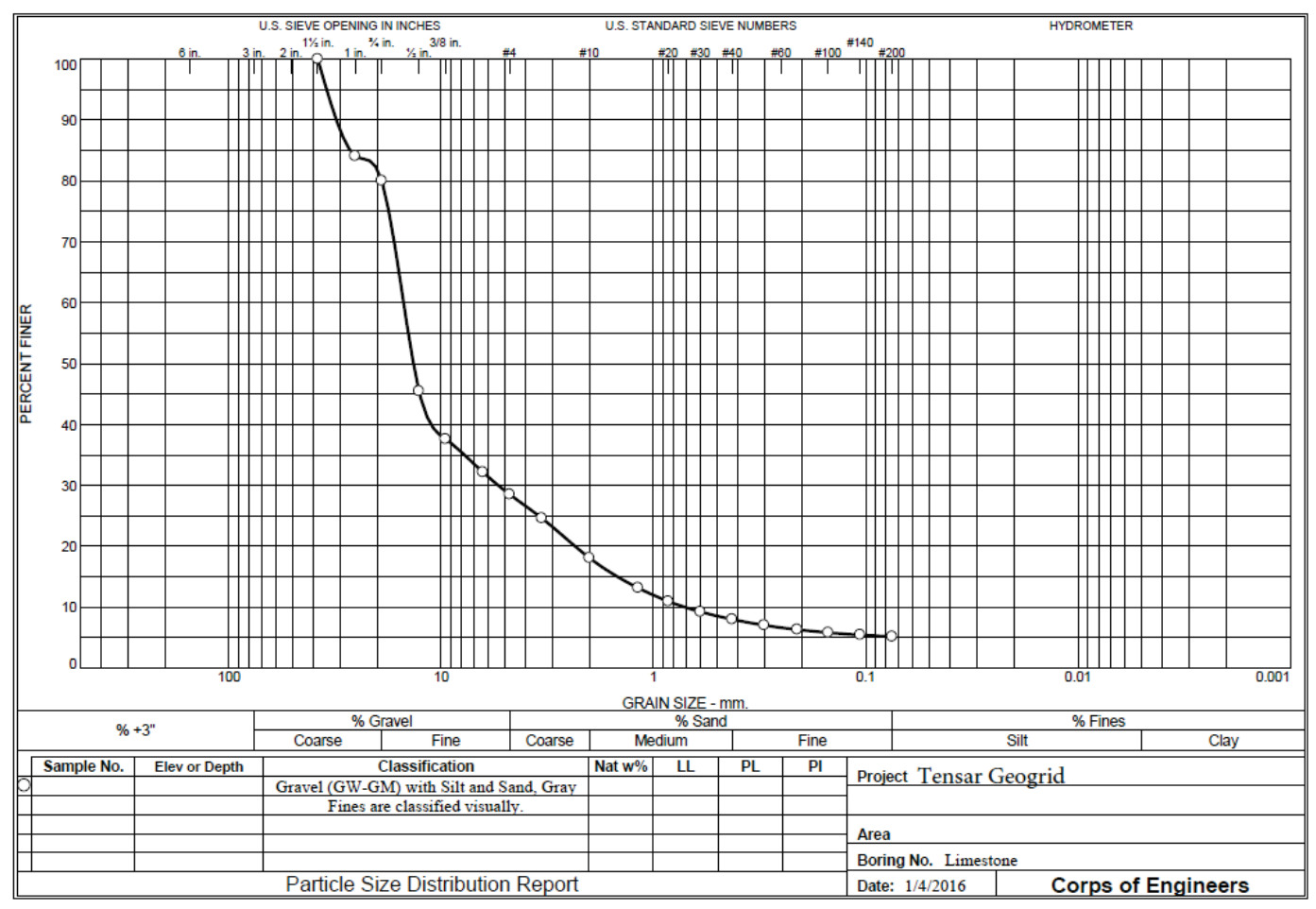

Figure 6. Limestone base moisture/density relationship.

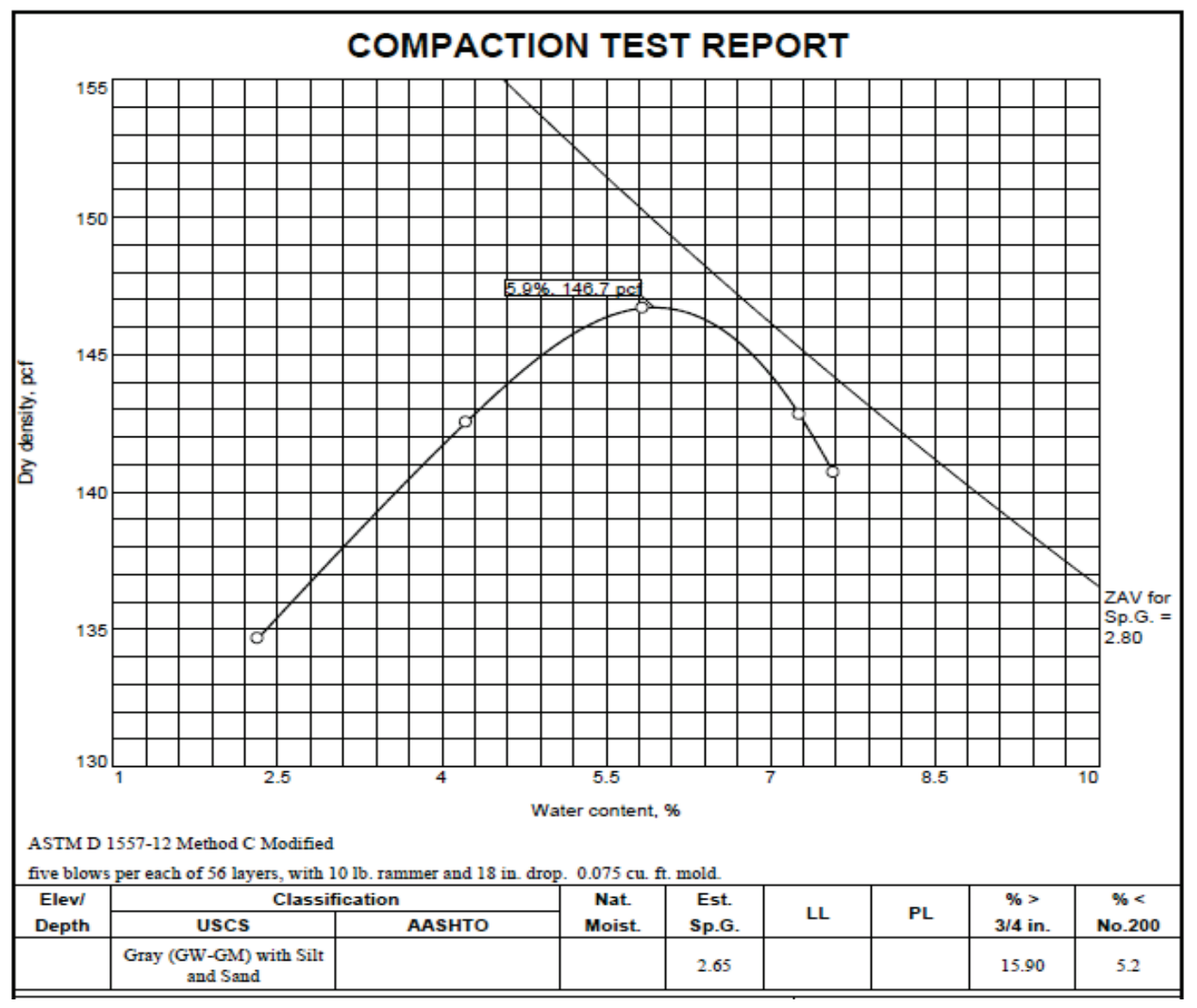




\subsection{Asphalt}

A 9.5-mm nominal maximum aggregate size (NMAS) HMA surface mixture was selected for placement of the final wearing surface on both test items. The asphalt mixture was one that is representative of the local highway mix used on medium-traffic-level roadways in Mississippi. Mixture properties were adjusted to closely replicate those used in previous geogrid evaluation studies. Pertinent mixture properties, including control values (Norwood and Tingle 2014) are presented in Table 1.

Table 1. Hot-mix asphalt properties.

\begin{tabular}{|c|c|c|c|}
\hline \multicolumn{2}{|c|}{ Test Property } & $\begin{array}{c}\text { Item } 1 \\
\& \\
\text { Item } 2\end{array}$ & $\begin{array}{c}\text { Control } \\
\text { 4-in. Nominal AC } \\
\text { Unstabilized Base } \\
\text { (Norwood and } \\
\text { Tingle 2014) }\end{array}$ \\
\hline \multicolumn{2}{|l|}{$N_{\text {design }}$} & 75 & 75 \\
\hline \multicolumn{2}{|l|}{ Binder Grade } & PG 67-22 & PG 67-22 \\
\hline \multicolumn{2}{|c|}{ Mixing Temp ( $\left.{ }^{\circ} \mathrm{F}\right)$} & 310 & 310 \\
\hline \multicolumn{2}{|c|}{ Compaction Temp ( $\left.{ }^{\circ} \mathrm{F}\right)$} & 300 & 292 \\
\hline \multirow{11}{*}{ 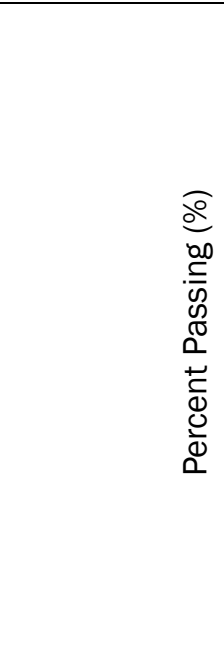 } & 1.0 in. $(25.0 \mathrm{~mm})$ & 100 & 100 \\
\hline & $3 / 4$ in. $(19.0 \mathrm{~mm})$ & 100 & 100 \\
\hline & $1 / 2$ in. $(12.5 \mathrm{~mm})$ & 100 & 100 \\
\hline & $3 / 8$ in. $(9.5 \mathrm{~mm})$ & 93 & 95 \\
\hline & $\# 4(4.75 \mathrm{~mm})$ & 57 & 54 \\
\hline & \#8 (2.36 mm) & 38 & 34 \\
\hline & \#16 (1.18 mm) & 27 & 27 \\
\hline & \#30 (0.60 mm) & 22 & 20 \\
\hline & \#50 (0.30 mm) & 12 & 7 \\
\hline & $\# 100(0.15 \mathrm{~mm})$ & 7 & 5 \\
\hline & \#200 (0.075 mm) & 5.1 & 3.8 \\
\hline \multicolumn{2}{|l|}{ RAP (\%) } & 20 & 15 \\
\hline \multicolumn{2}{|l|}{ RAP AC (\%) } & 5.0 & 5.5 \\
\hline \multicolumn{2}{|l|}{$\mathrm{G}_{\mathrm{sb}}$} & 2.510 & 2.6 \\
\hline \multicolumn{2}{|l|}{$\mathrm{P}_{\mathrm{b}}(\%)$} & 5.7 & 5.7 \\
\hline \multicolumn{2}{|l|}{$\mathrm{G}_{\mathrm{mm}}$} & 2.361 & 2.429 \\
\hline \multicolumn{2}{|l|}{ VMA (\%) } & 15.1 & 15.4 \\
\hline \multicolumn{2}{|l|}{ VFA (\%) } & 73.5 & 74.0 \\
\hline \multicolumn{2}{|l|}{$\mathrm{P}_{200 / \mathrm{P}_{\text {be }}}$} & 1.02 & 0.76 \\
\hline
\end{tabular}




\subsection{Geogrids}

The geogrids evaluated in this study were both multi-axial geogrid products manufactured from a punched and drawn polypropylene sheet. The geogrids have a hexagonal structure forming a series of triangular apertures. Nominal index properties provided for each geogrid are presented in Table 2.

Table 2. Geogrid physical properties.

\begin{tabular}{|l|l|l|l|l|l|l|}
\hline \multirow{2}{*}{\multicolumn{1}{|c|}{ Index Property }} & \multicolumn{3}{|c|}{ TX5 (Item 1) } & \multicolumn{3}{c|}{ TX8 (Item 2) } \\
\cline { 2 - 8 } & Longitudinal & Diagonal & Transverse & Longitudinal & Diagonal & Transverse \\
\hline Rib pitch, mm (in.) & $40(1.60)$ & $40(1.60)$ & - & $33(1.30)$ & $33(1.30)$ & - \\
\hline Mid-rib depth, mm (in.) & - & $1.3(0.05)$ & $1.2(0.05)$ & - & $1.6(0.06)$ & $1.2(0.05)$ \\
\hline Mid-rib width, mm (in.) & -- & $0.9(0.04)$ & $1.2(0.05)$ & - & $0.4(0.02)$ & $0.7(0.03)$ \\
\hline
\end{tabular}




\section{Instrumentation}

Instrumentation was installed in the subgrade, base course, and HMA surface course to monitor pavement response during test-section trafficking. Sensors used to capture the pavement response included earth pressure cells (EPCs), single-depth deflectometers (SDDs), and asphalt strain gauges (ASGs). Pore-water pressure, temperature sensors, and moisture sensors were installed to monitor environmental parameters. Figure 7 and Figure 8 show the plan and profile view of the typical instrumentation layout for each traffic lane, respectively.

\subsection{Earth pressure cells}

Vertical stresses in the base course and subgrade were measured using 9in.-diam Geokon EPCs. EPCs provide a quantitative measurement of the vertical distribution of the stresses within each traffic lane during testing. Cells with a maximum pressure range of 100 psi were installed in the subgrade, and 200-psi EPCs were installed in the base course. The EPCs in the base course were located $2 \mathrm{in}$. below the top of the base, while the EPCs placed in the subgrade were located 2 in. below the top of the subgrade. Figure 9 shows an EPC being installed 2 in. below the surface of the subgrade at the interface with the base course.

Figure 7. Plan view of instrumentation layout.

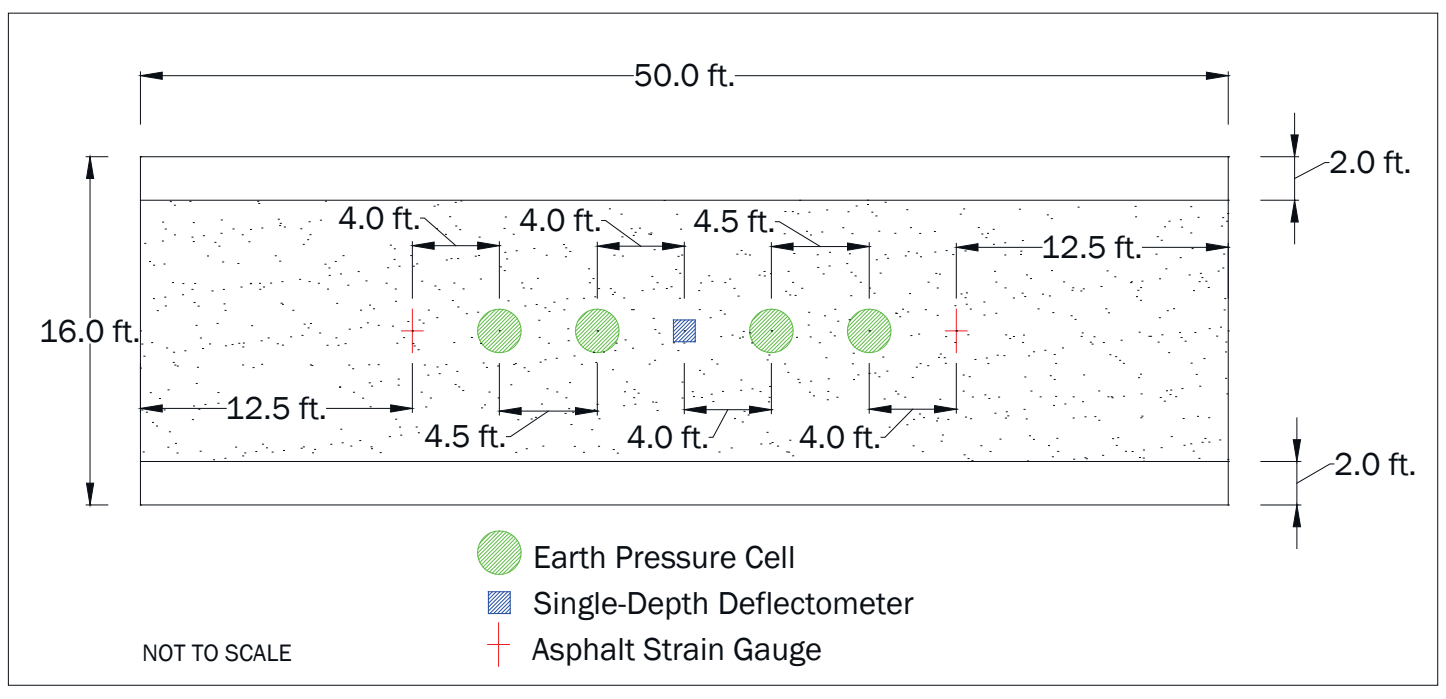


Figure 8. Profile view of instrumentation layout.

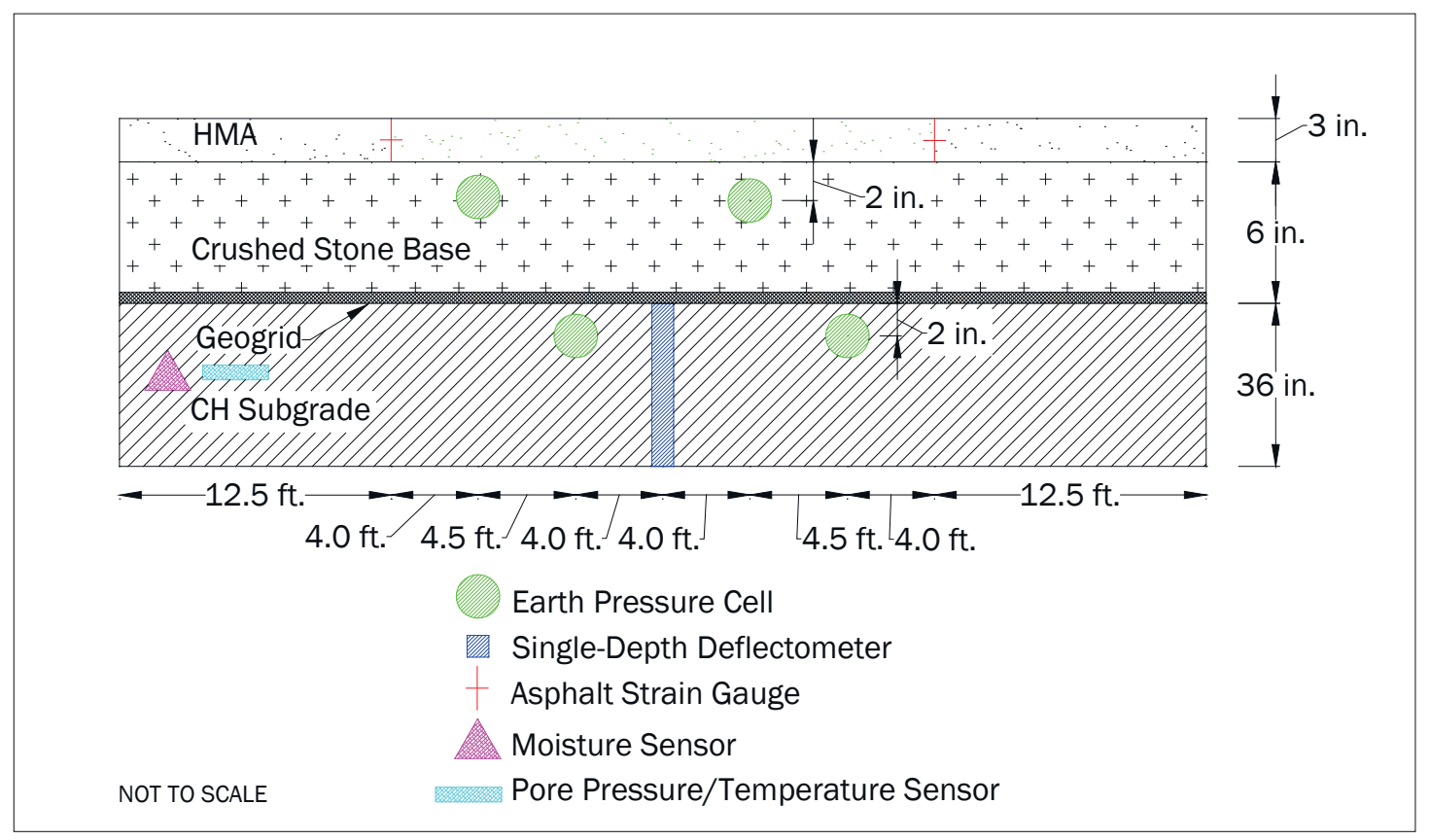

Figure 9. Earth pressure cell installation in subgrade.

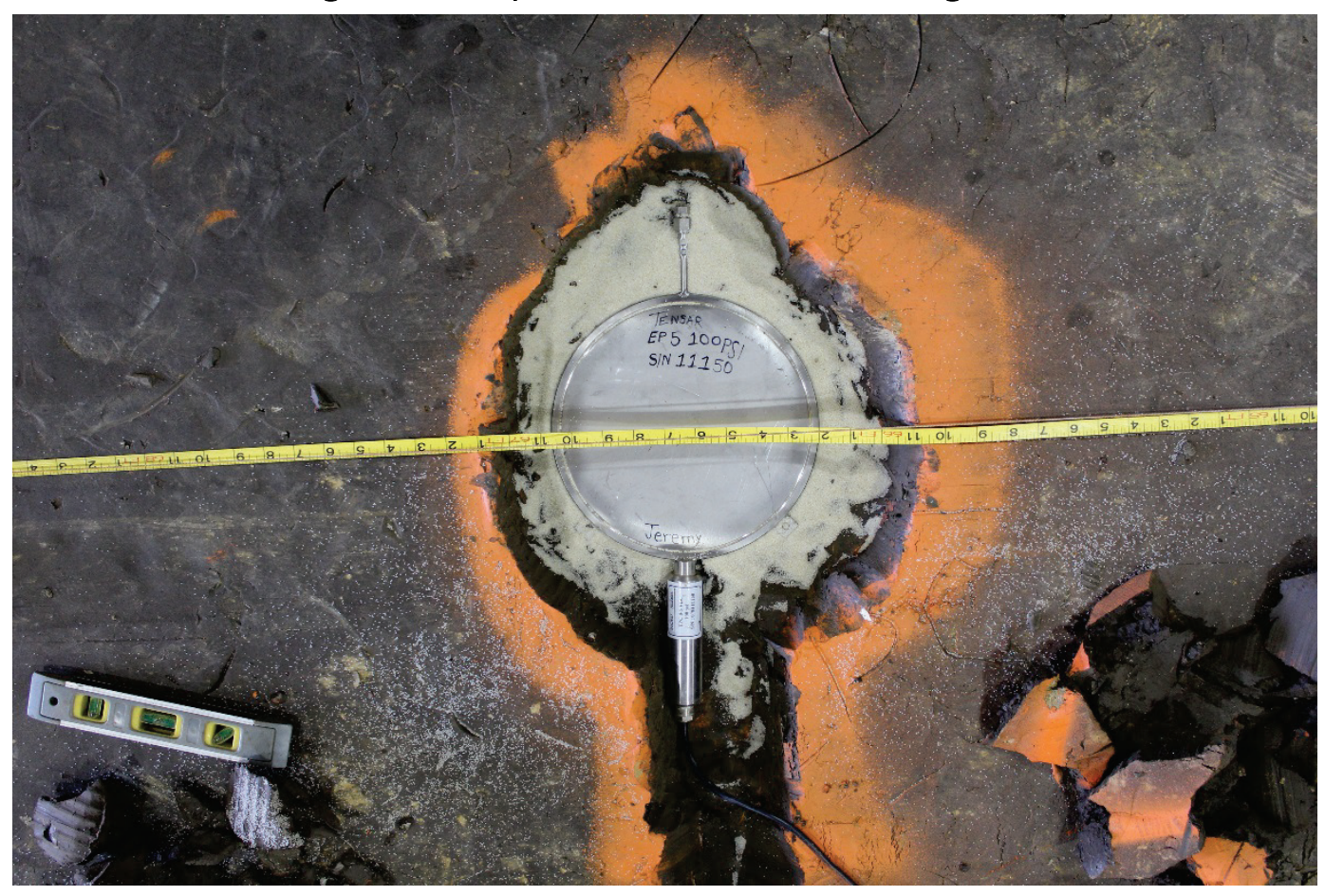




\subsection{Asphalt strain gauges}

Tensile strain at the bottom of an HMA layer provides a quantitative measure of the pavement response during trafficking. The tensile strain at the bottom of the asphalt is a key response parameter linked to fatigue damage in the HMA layer. For this study, strain at the bottom of the HMA surface was measured using dynamic asphalt strain gauges (ASGs) in both the transverse and longitudinal directions. The ASGs were manufactured by Tokyo Sokki and are capable of measuring a range of $\pm 5,000$ microstrain. The gauges were adhered to the surface of the base course with a heated asphalt binder, and HMA from the asphalt paver was placed as cover over each of the gauges immediately prior to paving of the entire test section. This process is shown in Figure 10 and Figure 11, respectively.

Figure 10. Asphalt strain gauge adhered to crushed stone base.

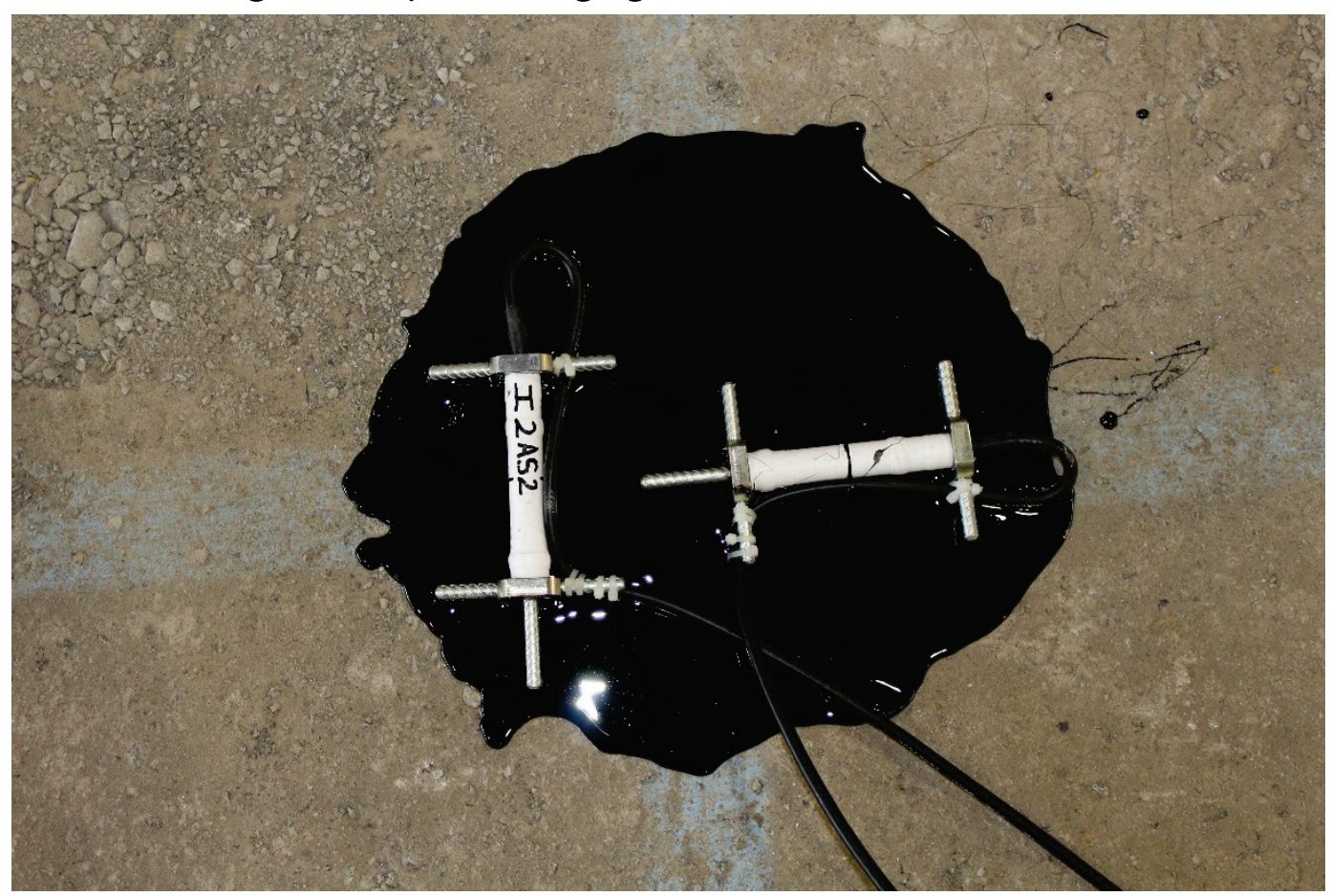


Figure 11. Asphalt strain gauge covered with HMA prior to paving.

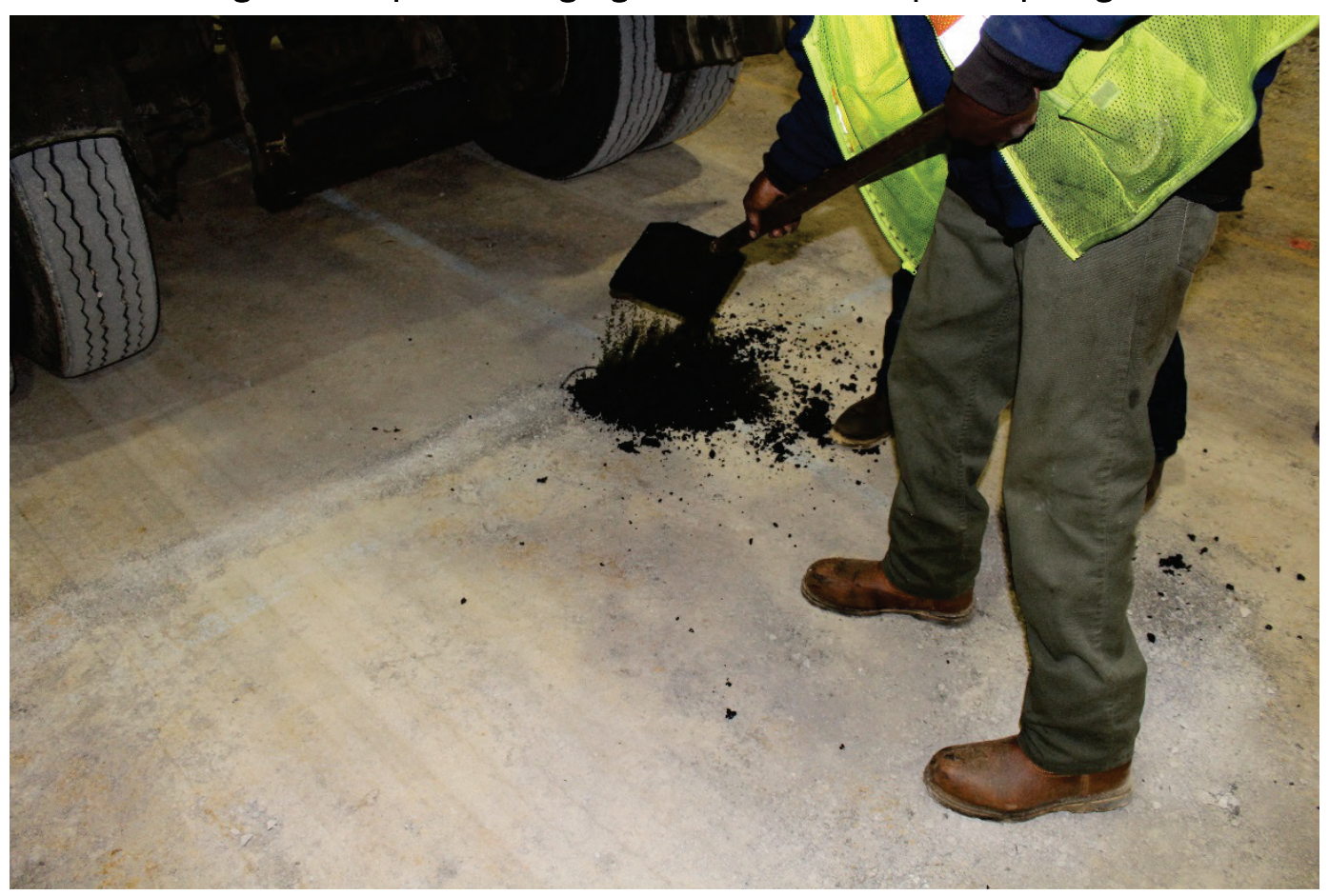

\subsection{Single-depth deflectometer}

Measurements of deformations in the subgrade are used to quantify the stabilization benefits of a geogrid as well as assisting with the validation of the failure mechanism within the pavement structure. Potential reductions in vertical stresses at the subgrade should also be reflected as reductions in the deformation. In theory for pavements with similar structural components, the geogrid-stabilized pavement should show lower deflections than the unstabilized pavement at a given traffic level.

Vertical deflections in the subgrade were measured using single-depth deflectometers (SDDs). One SDD was placed in the middle of each test item along the centerline of traffic. The SDD was placed such that the shaft was anchored at a depth of $8 \mathrm{ft}$ from the top of the subgrade. A linear velocity displacement transducer (LVDT) with a range of $\pm 2 \mathrm{in}$. was placed in the housing such that it was in contact with both the anchor rod and the surface plate as shown in Figure 12. Thus, the LVDT measured movement of the plate 2 in. below the base-subgrade interface relative to the control point located at a depth of $8 \mathrm{ft}$. 
Figure 12. Single-depth deflectometer installation.

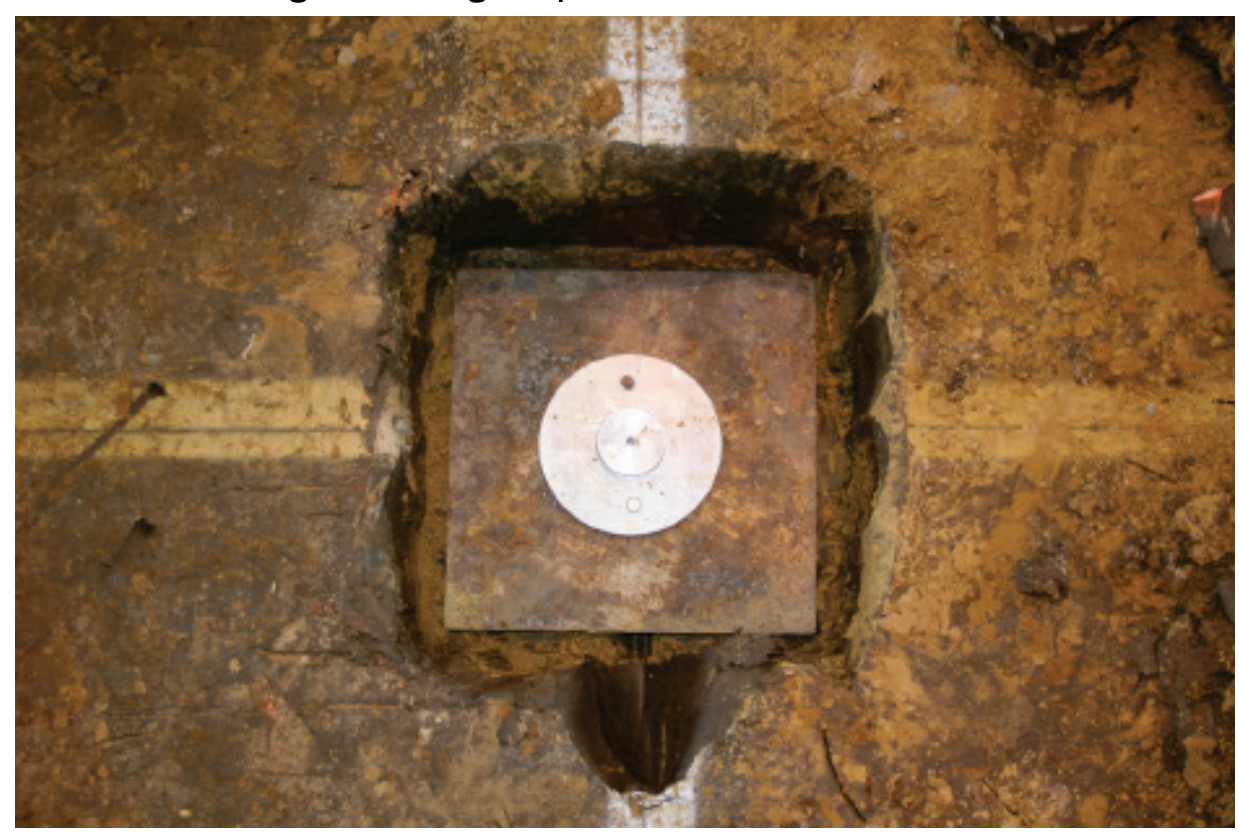




\section{Pavement Characterization}

\subsection{As-built properties}

Quality control tests were performed during construction of each material lift to ensure target values were achieved and to monitor material consistency. Dry density and moisture content were measured using a nuclear moisture density device in accordance with ASTM D6938-15 to verify the uniformity of each material lift. Field in-place CBR tests were performed in general accordance with ASTM D4429-09a on each compacted lift to ensure target values were achieved. To further characterize the strength of the completed base and subgrade layers, Dynamic Cone Penetrometer (DCP) tests were performed in accordance with ASTM D6951-09. Asphalt cores were obtained from each test item, and core densities were determined in accordance with AASHTO T166.

As-built material properties of the base and subgrade are summarized in Table 3. Also included are the as-built control section properties from a previous test-section construction that included a comparable unstabilized control section (Norwood and Tingle 2014).

Table 3. As-built section properties.

\begin{tabular}{|l|c|c|c|}
\hline \multicolumn{1}{|c|}{ Property } & $\begin{array}{c}\mid \\
\text { Item 1 } \\
\text { TX5 Stabilized Base }\end{array}$ & $\begin{array}{c}\text { Control } \\
\text { Item 2 } \\
\text { TX8 Stabilized Base } \\
\text { Unstabilized Base } \\
\text { (Norwood and } \\
\text { Tingle 2014) }\end{array}$ \\
\hline Wet Density (pcf) & CH Subgrade Properties \\
\hline Dry Density (pcf) & $88.5 \pm 1.1$ & $88.7 \pm 1.2$ & 116.9 \\
\hline Nuclear Moisture Content (\%) & $31.6 \pm 0.8$ & $31.6 \pm 1.1$ & 88.9 \\
\hline Oven-Dried Moisture (\%) & $32.7 \pm 1.3$ & $32.6 \pm 1.2$ & 30.0 \\
\hline In-Place CBR (\%) & $5.9 \pm 0.2$ & $5.9 \pm 0.2$ & 5.9 \\
\hline & Crushed Limestone Properties & 143.0 \\
\hline Wet Density (pcf) & $138.8 \pm 1.6$ & $141.5 \pm 1.8$ & 138.1 \\
\hline Dry Density (pcf) & $134.5 \pm 1.5$ & $137.2 \pm 1.7$ & 3.6 \\
\hline Nuclear Moisture Content (\%) & $3.3 \pm 0.1$ & $3.3 \pm 0.2$ & 2.4 \\
\hline Oven-Dried Moisture (\%) & $3.0 \pm 0.3$ & $3.2 \pm 0.2$ & 95.3 \\
\hline In-Place CBR (\%) & $98.6 \pm 9.1$ & $100(+) \pm 4.9$ & 7.7 \\
\hline Thickness (in.) & $5.82 \pm 0.36$ & $5.90 \pm 0.33$ & \\
\hline
\end{tabular}




\begin{tabular}{|c|c|c|c|}
\hline Property & $\begin{array}{c}\text { Item } 1 \\
\text { TX5 Stabilized Base }\end{array}$ & $\begin{array}{c}\text { Item } 2 \\
\text { TX8 Stabilized Base }\end{array}$ & $\begin{array}{c}\text { Control } \\
\text { 4-in. Nominal AC } \\
\text { Unstabilized Base } \\
\text { (Norwood and } \\
\text { Tingle 2014) }\end{array}$ \\
\hline \multicolumn{4}{|c|}{ Hot-Mix Asphalt Properties } \\
\hline Density (\% of $\mathrm{Gmm}_{\mathrm{m}}$ ) & $93.4 \pm 0.5$ & $93.2 \pm 1.0$ & - \\
\hline Thickness (in.) & $3.20 \pm 0.21$ & $3.22 \pm 0.11$ & $4.0^{*}$ \\
\hline
\end{tabular}

*Nominal thickness reported

\subsection{Dynamic cone penetrometer}

A series of dynamic cone penetrometer (DCP) tests were performed to further characterize the strength of the unbound pavement layers. DCP tests were performed after construction of the base and subgrade layers on both sides of the traffic lane, following the procedures described by ASTM D 6951-09. Measured values of the DCP index (millimeters of penetration per hammer blow) were converted to CBR strength using the relationship developed by Webster et al. (1992, 1994). As-built DCP results are shown for Item 1 Station 25 West in Figure 13 and Item 2 Station 25 East in Figure 14.

\subsection{Falling weight deflectometer}

Falling weight deflectometer tests were performed on the surface of both test items after construction and prior to trafficking. The measured impulse stiffness modulus (ISM) was used to evaluate the stiffness of the constructed pavement section and provide a baseline for subsequent comparison under traffic. The ISM is the ratio of the applied load to the measured plate deflection with higher values representing a stiffer pavement structure. Additionally, the ISM values were compared to values obtained from previous test sections to verify the validity of performance comparisons. As-built ISM values for Item 1, Item 2, and the unstabilized control (Norwood and Tingle 2014) are presented in Figure 15. As-built ISM values for each test item were found to be relatively consistent along the length of each test item. Minor differences were observed in the test items with Item 2 having a slightly higher ISM value than Item 1. Both stabilized items were found to have lower ISM values than the unstabilized item. This was anticipated as the unstabilized item had an additional 2 in. of base course and 1 in. of HMA. 
Figure 13. As-built DCP results for Item 1 Station 25, West.

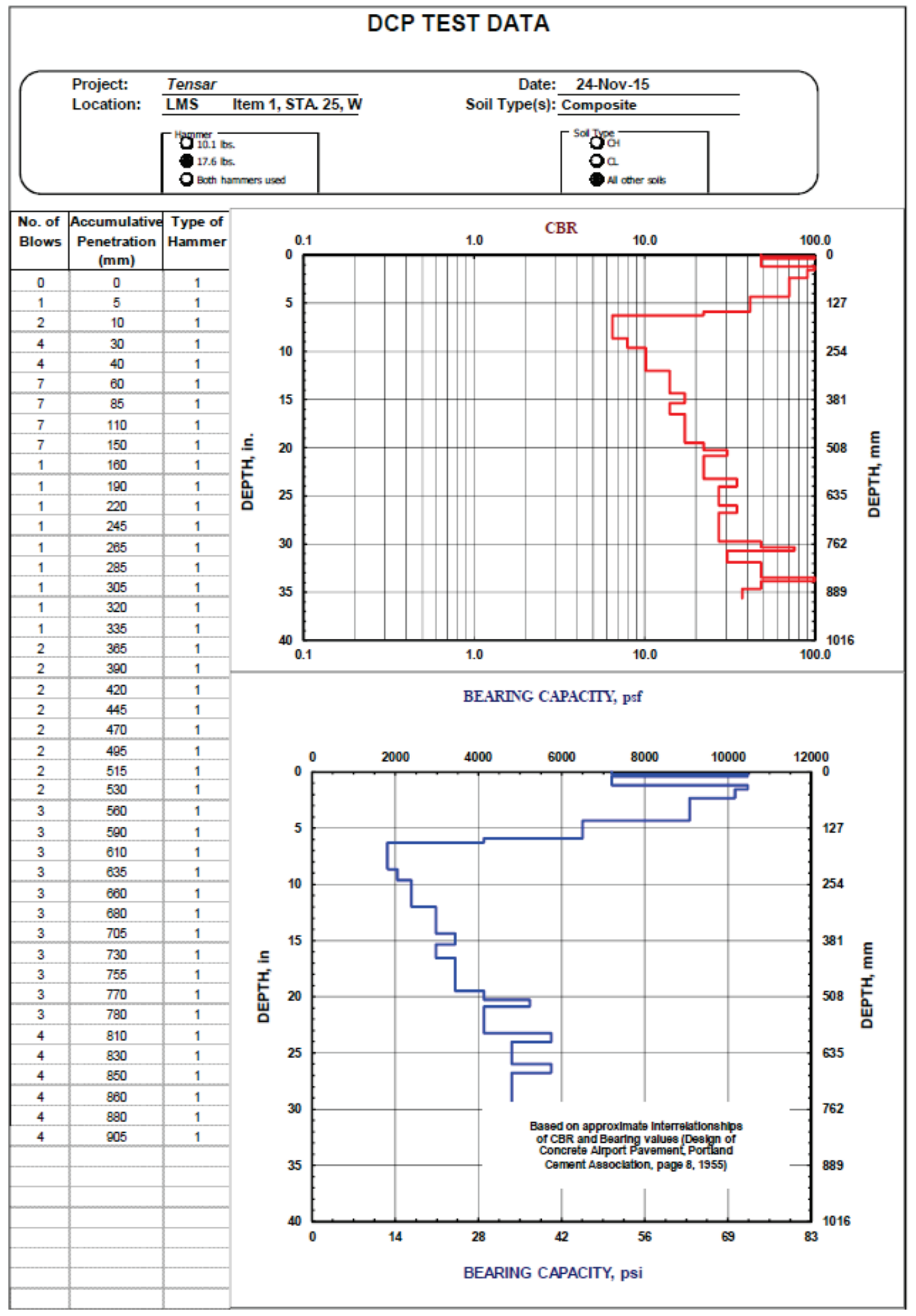


Figure 14. As-built DCP results for Item 2 Station 25, East.

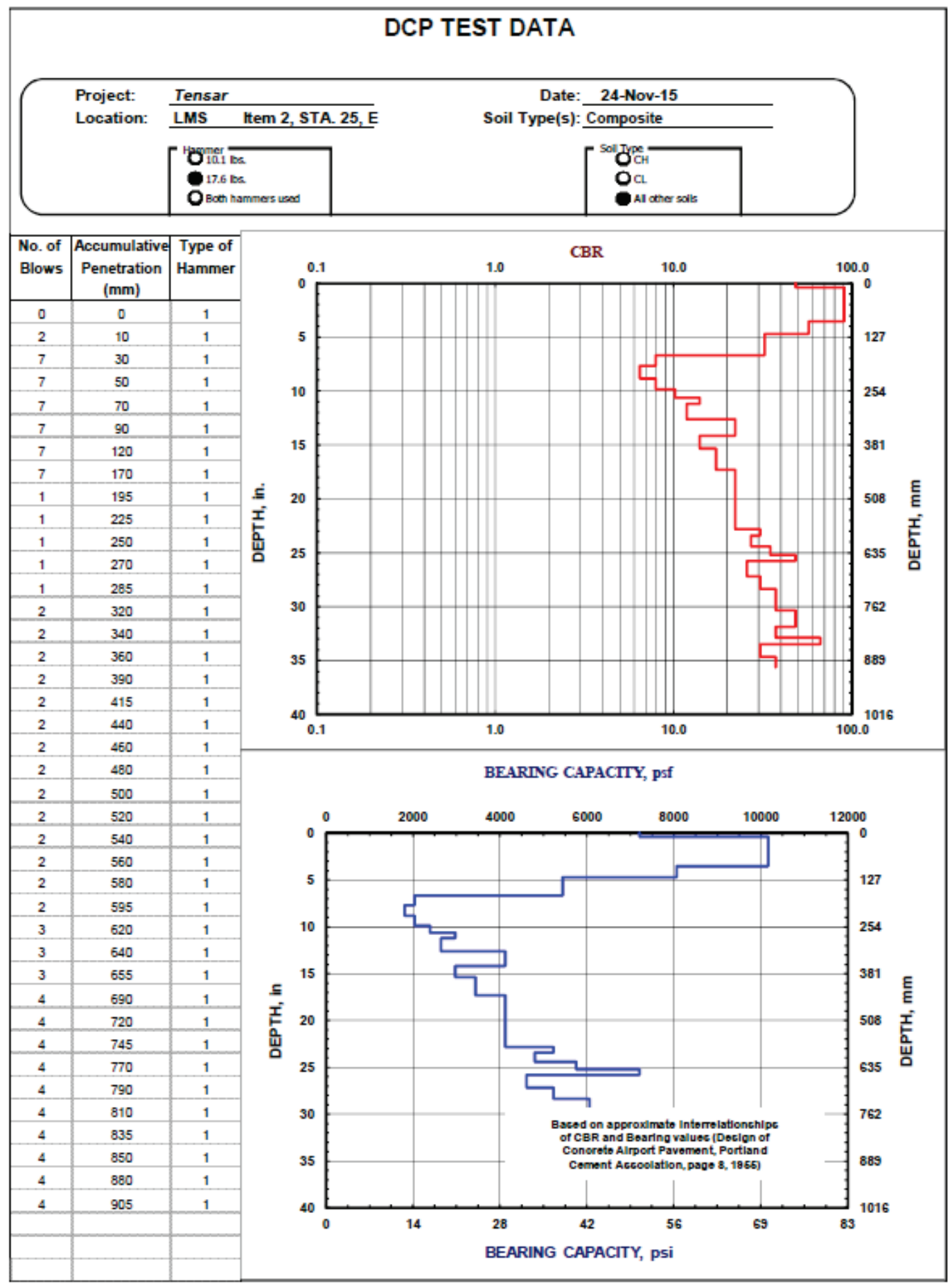


Figure 15. As-built ISM values.

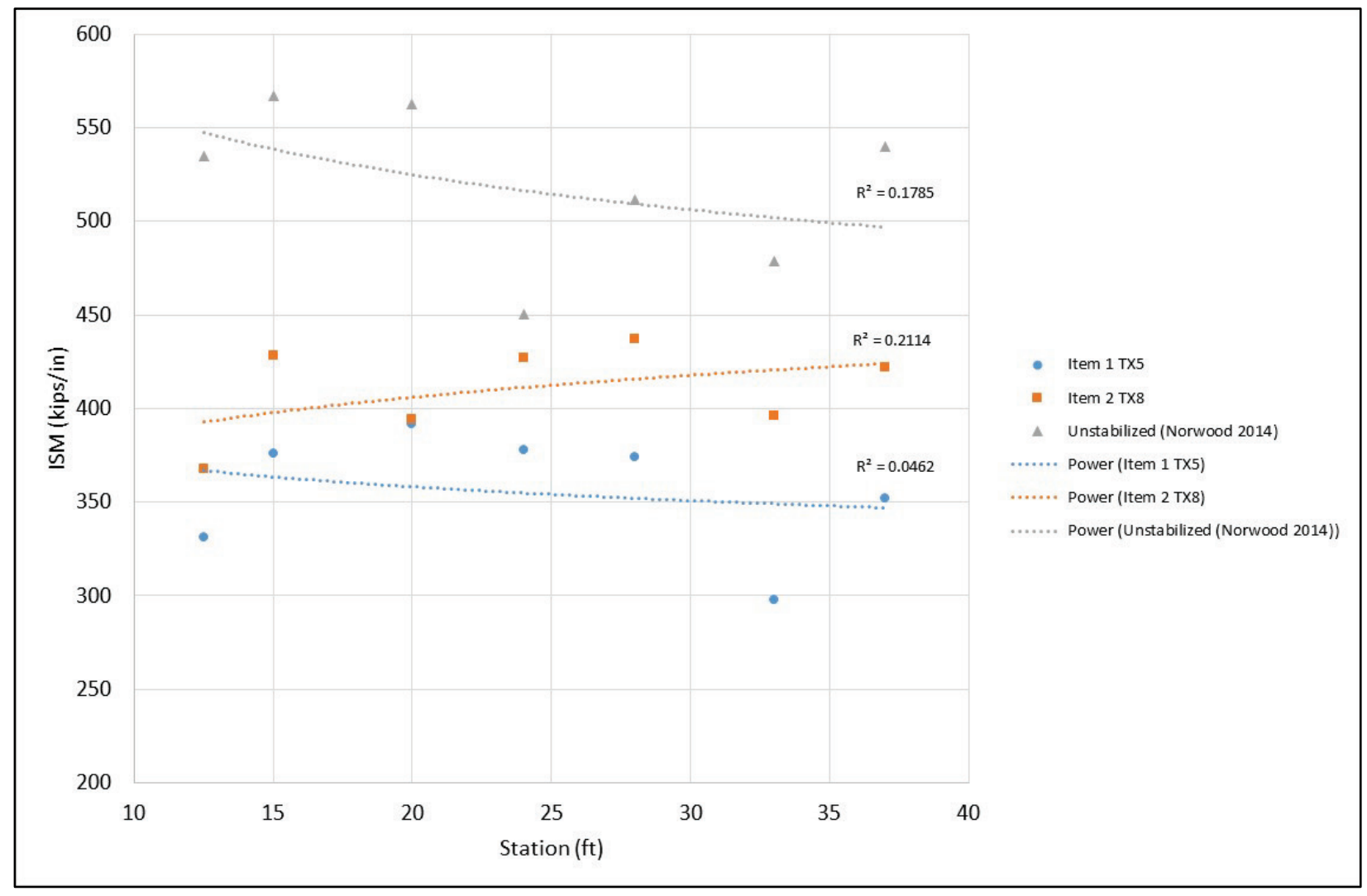




\section{Traffic Testing}

Traffic testing on both test items was performed utilizing a dual-wheel tandem axle gear (Figure 16) on the ERDC HVS. The gear configuration was loaded to a 20,000-lb nominal load and was verified prior to testing by weighing each axle with portable aircraft wheel scales. Tire pressures were monitored and maintained at 120 psi throughout traffic testing. The equivalent single axle load factor for this configuration was 2.08; therefore, each pass of the HVS was equal to 2.08 equivalent single axle loads (ESALS). The environmental chamber was maintained at a target pavement temperature of $77^{\circ} \mathrm{F}$ with an allowable range of $\pm 5^{\circ} \mathrm{F}$ during trafficking to minimize the effect of temperature variation on rutting performance.

Each test item was trafficked utilizing a normally distributed bi-directional traffic pattern shown in Figure 17. The lateral offset indices refer to 1-in. increments along which the axle shifts laterally, resulting in a total lateral wander of approximately 3 feet. A 3 -ft-wide wander pattern was utilized to mimic previous studies and to duplicate observations in other test sections.

Figure 16. Dual-wheel tandem axle configuration.

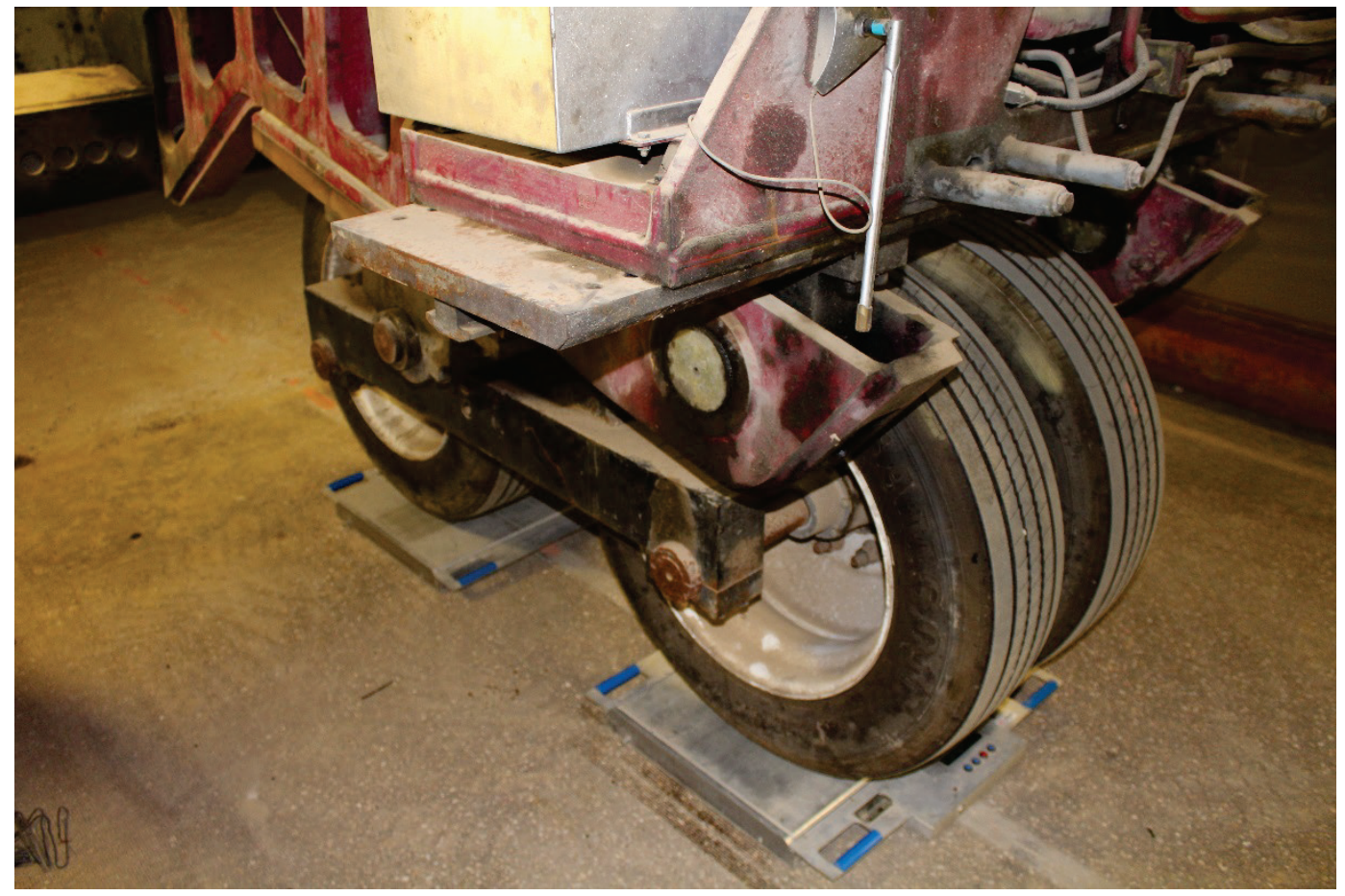


Figure 17. Normally distributed traffic pattern.

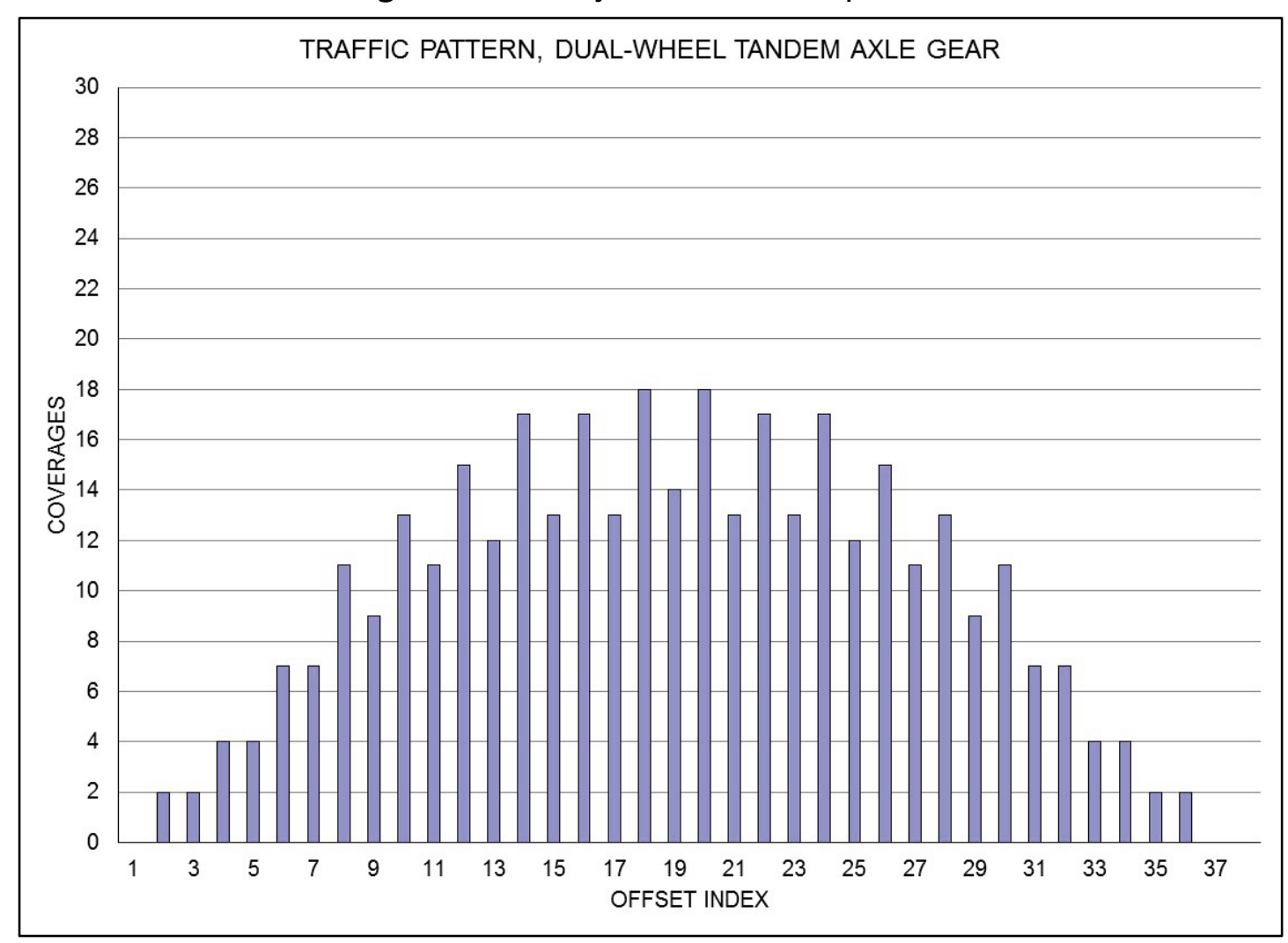




\section{Results}

Failure of the flexible pavement test items was defined as 1 in. of rutting. This failure definition was based on the concept of pavement serviceability and the fact that pavement serviceability begins to decrease exponentially in flexible pavements after 1 in. of rutting. Results are presented to document the changes in vertical alignment and instrumentation response at each traffic interval. Included within each results section are the responses documented from the unstabilized control section presented by Norwood and Tingle (2014).

\subsection{Surface deformations}

Surface deformation and rut depth measurements were made at predetermined traffic levels throughout the testing period. Surface deformation measurements represent changes in elevation and were made along the centerline and designated cross-sections of each test item. Surface deformation measurements were made utilizing robotic total station equipment to an accuracy of 0.08 in. Rut depth measurements were made by placing a metal straight edge across the traffic lane at designated cross sections and measuring the maximum rut depth using a machined depth wedge to an accuracy of $1 / 16 \mathrm{in}$. The maximum rut depth includes permanent surface deformation and upheaval along the edge of the traffic pattern. A schematic of the maximum rut depth measurement procedure is shown in Figure 18.

Figure 18. Measurement of maximum rut depth.

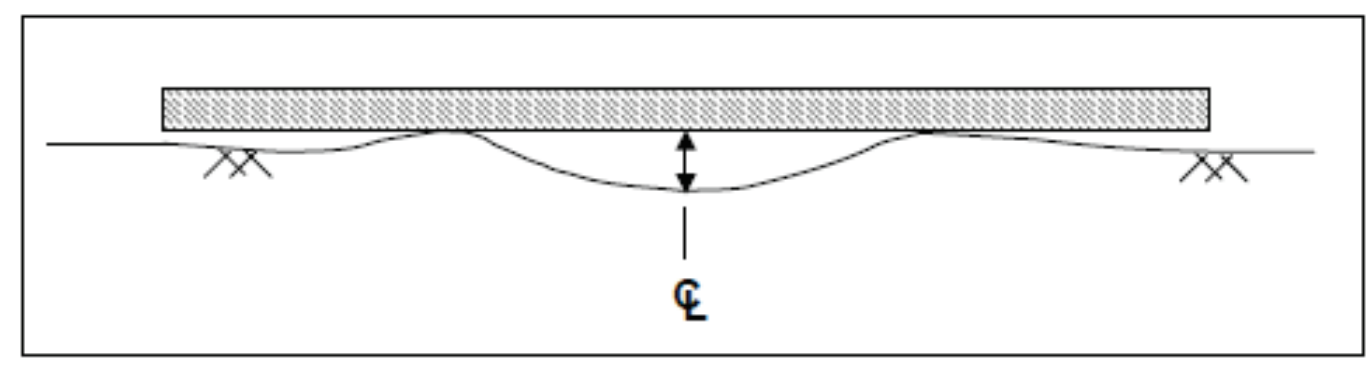

Maximum rut depths are presented in Figure 19 and Table 4. These values represent the maximum rut depth of $50 \%$ of the traffic lane. Maximum rut depth measurements were taken at stations 12.5, 18.75, 25.0, 31.25, and 37.5 of each test item, and the average of the maximum rut depth 
measurements was reported. The test results indicate the stabilized test items displayed approximately 50-60\% less rutting than the unstabilized control item despite the reduced base and surface layer thicknesses of the stabilized sections compared to the control section. Minimal differences in rutting were observed in Item 1 and Item 2, with Item 2 outperforming Item 1 at most traffic levels.

Surface deformation measurements presented in Figure 20 and Table 5 were obtained by averaging elevation measurements taken at $1-\mathrm{ft}$ increments along the centerline of the trafficked area. Measurements made at the outer 5 feet of the traffic centerline were excluded from the averaging calculations due to the potential for non-representative deformations caused by the change of direction of the HVS carriage. The test results indicate that the stabilized test items displayed approximatley 30-35\% less surface deformation than the unstabilized control item. Minimal differences in surface deformation were observed between Item 1 and Item 2, with Item 2 outperforming Item 1 at most traffic levels.

It should be noted that while a reduction in rutting and permanent deformation were observed in the stabilized items when compared to the unstabilized item, the overall magnitude of differences in the distress would be considered relatively small in practice.

Figure 19. Accumulated rut depth with traffic.

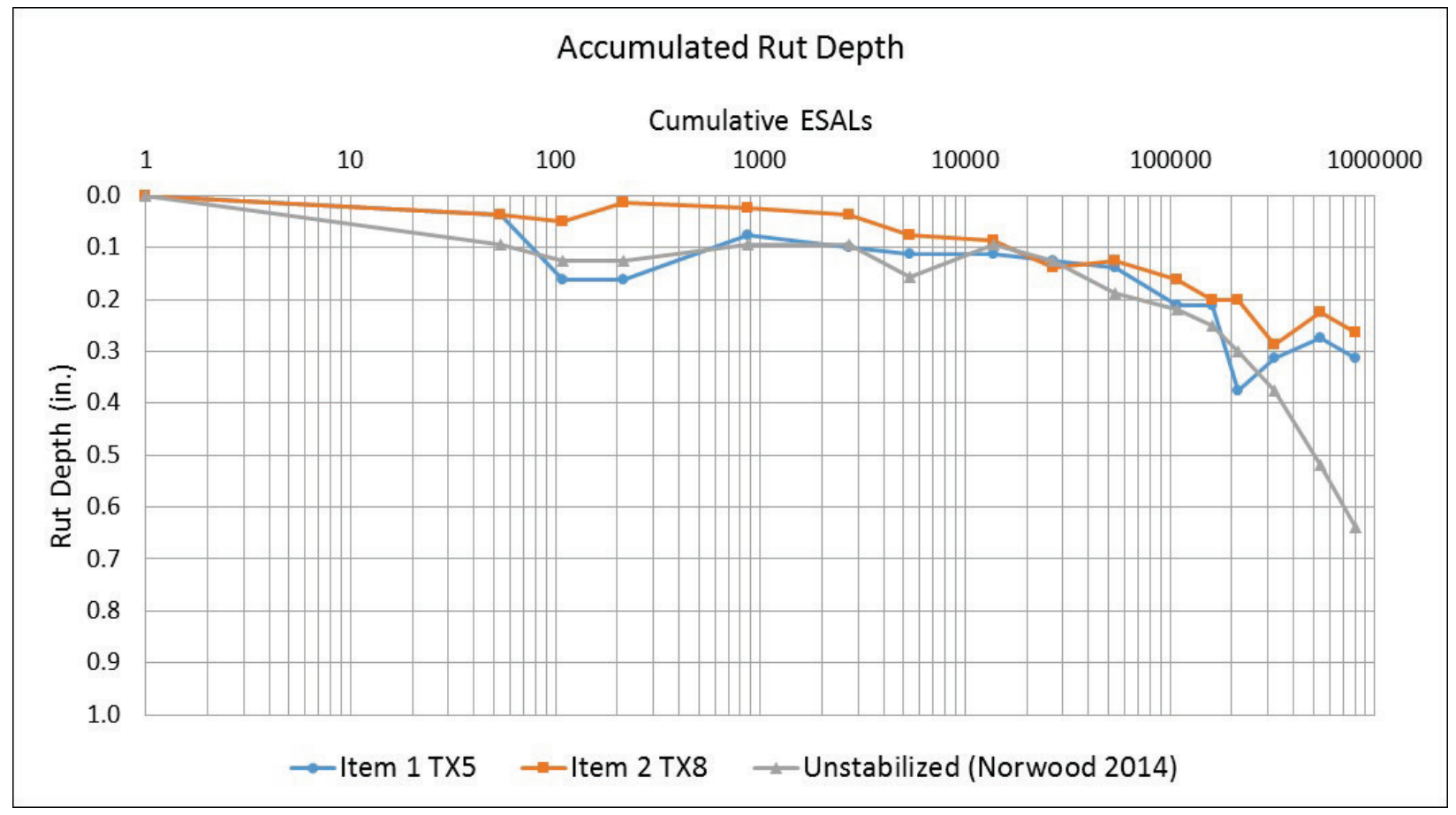


Table 4. Maximum rut depth measurements.

\begin{tabular}{|c|c|c|c|c|c|c|c|c|c|c|}
\hline \multirow[b]{2}{*}{ Test Item } & \multirow{2}{*}{$\begin{array}{l}\text { Pavement } \\
\text { Structure }\end{array}$} & \multicolumn{9}{|c|}{ ESALS } \\
\hline & & 54 & 108 & 216 & 865 & 27,040 & 54,080 & 162,240 & 324,480 & 811,200 \\
\hline Item 1 & $\begin{array}{l}\text { 3-in. HMA } \\
\text { 6-in. base } \\
\text { stabilized, TX5 }\end{array}$ & 0.038 & 0.163 & 0.163 & 0.075 & 0.125 & 0.138 & 0.213 & 0.313 & 0.313 \\
\hline Item 2 & $\begin{array}{l}\text { 3-in. HMA } \\
\text { 6-in. base } \\
\text { stabilized, TX8 }\end{array}$ & 0.038 & 0.050 & 0.013 & 0.025 & 0.138 & 0.125 & 0.200 & 0.288 & 0.263 \\
\hline Control & $\begin{array}{l}\text { 4-in. HMA } \\
\text { 8-in. base } \\
\text { unstabilized }\end{array}$ & 0.094 & 0.125 & 0.125 & 0.094 & 0.125 & 0.188 & 0.250 & 0.375 & 0.640 \\
\hline
\end{tabular}

Figure 20. Permanent surface deformation with traffic.

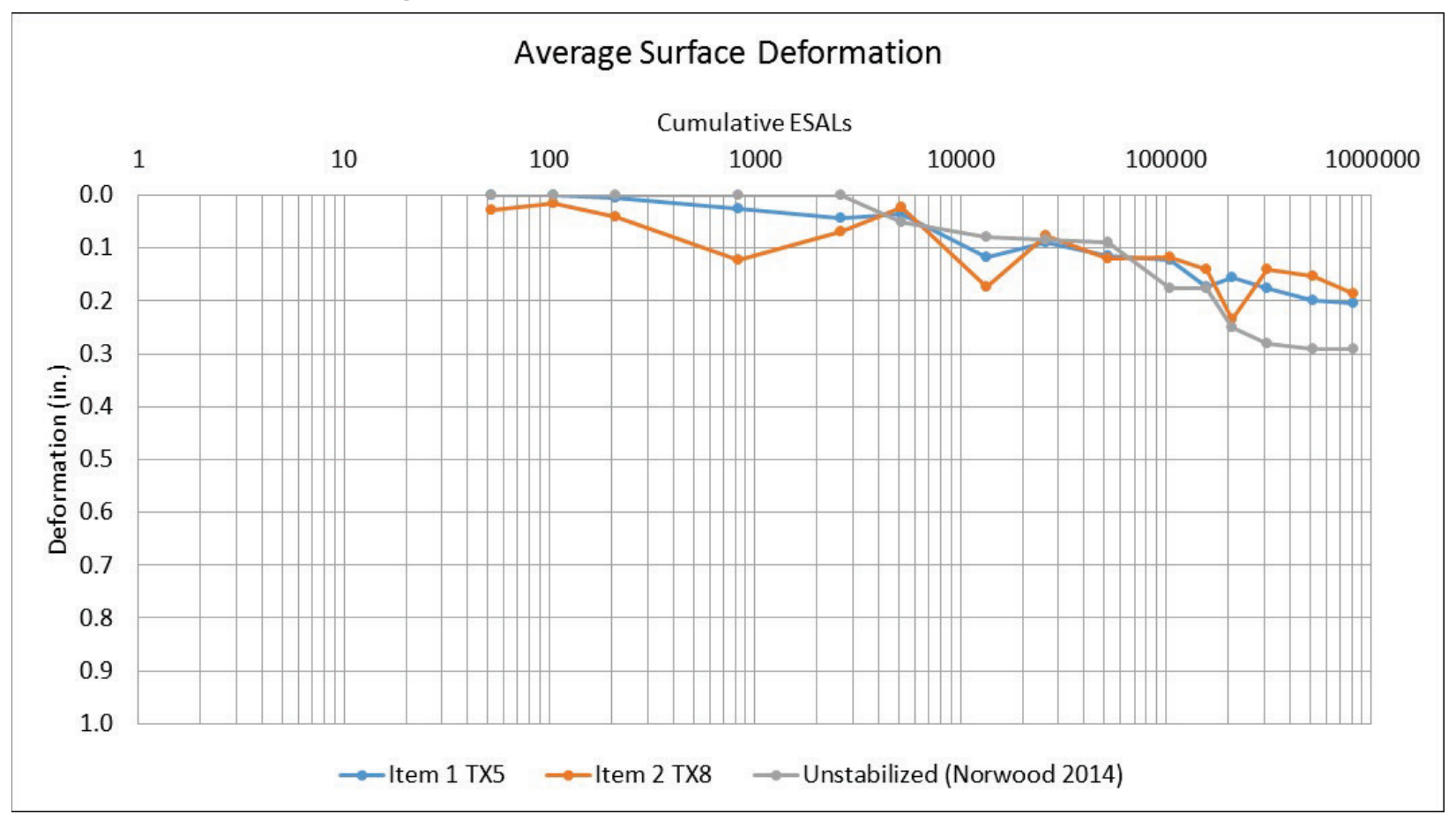

Table 5. Permanent surface deformation measurements.

\begin{tabular}{|c|l|c|c|c|c|c|c|c|c|c|}
\hline \multirow{2}{*}{$\begin{array}{c}\text { Test } \\
\text { Item }\end{array}$} & \multicolumn{1}{|c|}{$\begin{array}{c}\text { Pavement } \\
\text { Structure }\end{array}$} & \multicolumn{7}{|c|}{ ESALS } \\
\cline { 3 - 11 } Item 1 & $\begin{array}{l}\text { 3-in. HMA } \\
\text { 6-in. base } \\
\text { stabilized, TX5 }\end{array}$ & 0.000 & 0.000 & 0.005 & 0.025 & 0.090 & 0.115 & 0.175 & 0.176 & 0.203 \\
\hline Item 2 & $\begin{array}{l}\text { 3-in. HMA } \\
\text { 6-in. base } \\
\text { stabilized, TX8 }\end{array}$ & 0.027 & 0.016 & 0.040 & 0.124 & 0.077 & 0.121 & 0.141 & 0.140 & 0.187 \\
\hline Control & $\begin{array}{l}\text { 4-in. HMA } \\
\text { 8-in. base } \\
\text { unstabilized }\end{array}$ & 0.000 & 0.000 & 0.000 & 0.000 & 0.085 & 0.090 & 0.175 & 0.280 & 0.290 \\
\hline
\end{tabular}




\subsection{Falling weight deflectometer}

FWD data were collected at specified traffic intervals to monitor pavement structure stiffness. The ISM, which is the applied load divided by the measured load plate deflection, was used as the basis for comparison. FWD data were collected at Stations 12.5, 15, 20, 24, 28, and 37 at each designated traffic interval. Average as-built ISM values for Item 1 and Item 2 were $357 \mathrm{kips} / \mathrm{in}$. and $410 \mathrm{kips} / \mathrm{in}$., respectively. The average as-built ISM value for the control section was $521 \mathrm{kips} / \mathrm{in}$. The increased stiffness of the unstabilized section was expected due to the additional 2 in. of base course and additional 1 in. of HMA. Change in ISM values with traffic for each test item are presented in Figure 21.

Figure 21. ISM change with traffic.

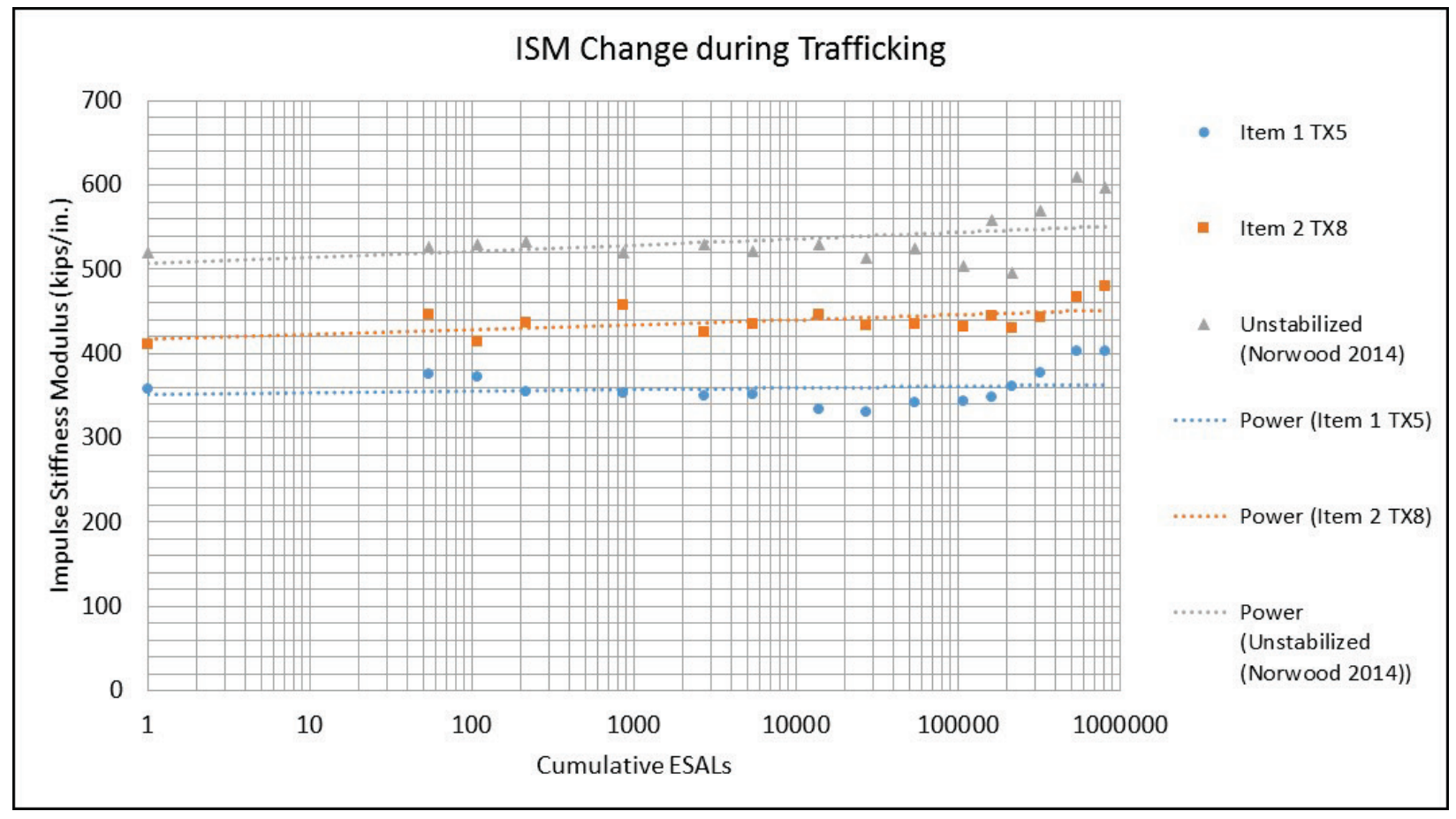

Under cumulative traffic loading, little change was observed in stiffness of the stabilized test items. A slight upward trend was noted at approximately 108,000 ESALS for each item trafficked that may have been a result of layer densification under sustained trafficking. The final ISM value for Item 1 was $402 \mathrm{kips} / \mathrm{in}$., representing an increase of $45 \mathrm{kips} / \mathrm{in}$. or approximately $13 \%$. The final ISM value for Item 2 was 480 kips/in., representing an increase of 70 kips/in. or approximately $17 \%$. 
The Base Damage Index (BDI) was calculated as the difference between the measured deflection at the load plate (D1) and the measured deflection at a 12-in. offset (D2) to determine the relative stiffness of the aggregate base course. Figure 22 presents a plot of the calculated average BDI for each section at each traffic interval. The test results indicate the base stiffness values for Item 1 were lower than the unstabilized item throughout the duration of trafficking. The increased stiffness of the unstabilized section was expected due to the additional 2 in. of base course. Base stiffness values in Item 2 were found to be generally the same as those calculated for the unstabilized section.

Figure 22. Base damage index with traffic.

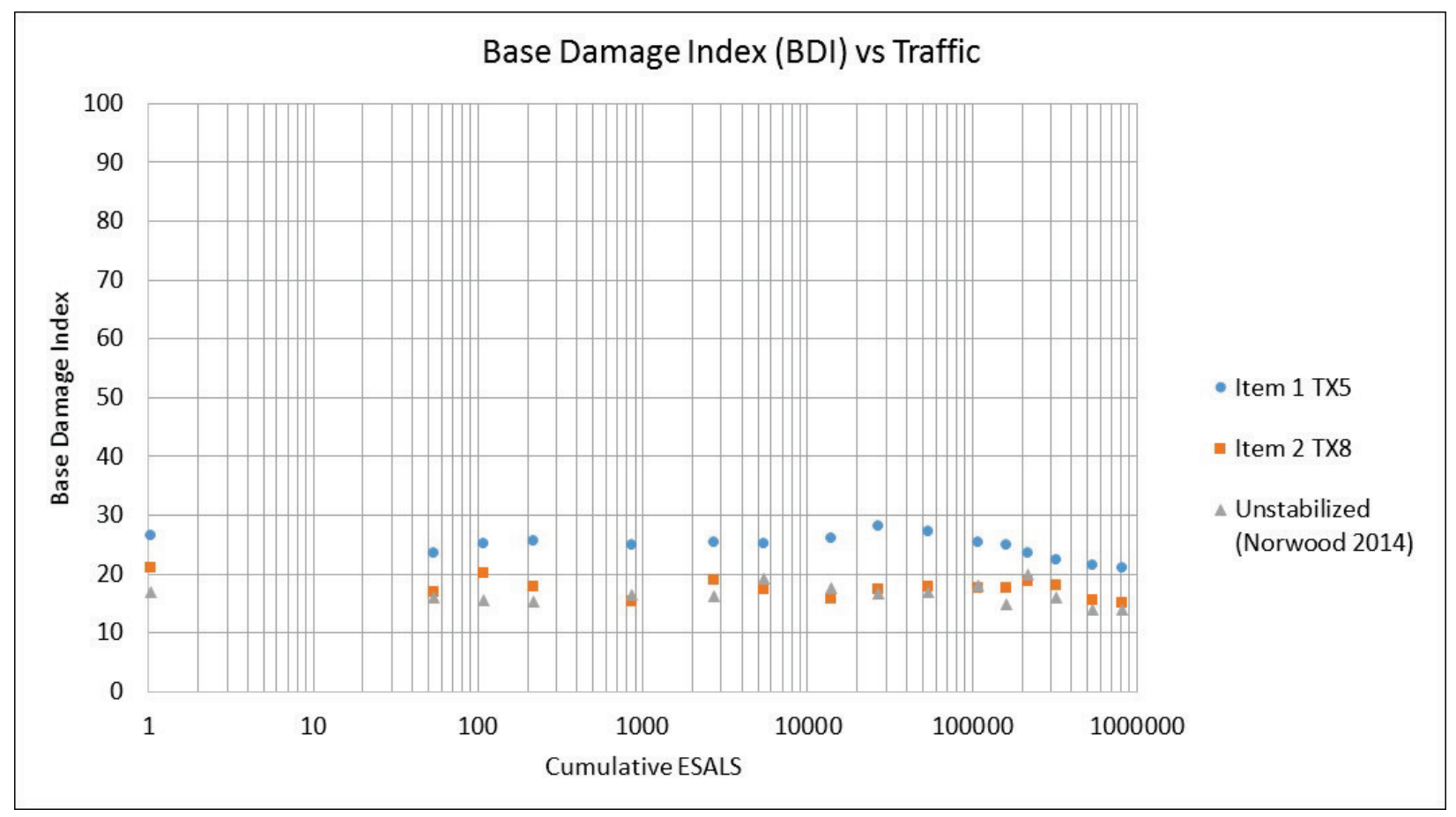

\subsection{Earth pressure cells}

Earth pressure cells were installed near the top of the base and near the top of the subgrade as described previously to collect dynamic stress response during trafficking. Locations and installation depths for each test item are presented in Table 6.

Predicted stresses within the pavement structure were calculated using the Pavement Engineering Utility Version 7 (PSEVEN). PSEVEN is a software tool developed at the ERDC for the analysis, design and evaluation of pavement structures. This tool implements pavement criteria and 
procedures contained in Department of Defense Unified Facilities Criteria (UFC) 3-260-02. PSEVEN can be used for the analysis of flexible, rigid, unsurfaced, and mat-surfaced pavements. Required pavement thicknesses, allowable loads and allowable passes are computed for one or more ground vehicles and aircraft. PSEVEN is able to use vehicle geometrical and load data from the standard database supplied with the pavement engineering and design software package PCASE 2.09. Custom vehicles can be created and managed to add vehicles not included in the standard vehicles database. PSEVEN can also be used to design and analyze pavements using the layered elastic theory. Other features of PSEVEN include: frost calculations, minimum thickness of asphalt surfaces, and Aircraft Classification Numbers. The calculated stresses using PSEVEN are presented in Table 6 with the measured responses recorded at the beginning of the traffic testing.

Table 6. Predicted and measured earth pressure cell responses.

\begin{tabular}{|l|l|l|l|l|c|c|c|c|}
\hline \multicolumn{2}{|l|}{} & $\begin{array}{l}\text { As-built } \\
\text { HMA } \\
\text { Thickness } \\
\text { (in.) }\end{array}$ & $\begin{array}{l}\text { As-built } \\
\text { Base } \\
\text { Thickness } \\
\text { (in.) }\end{array}$ & $\begin{array}{l}\text { EPC depth } \\
\text { from } \\
\text { surface (in.) }\end{array}$ & $\begin{array}{l}\text { Predicted } \\
\text { Stress } \\
\text { (psi) }\end{array}$ & $\begin{array}{l}\text { Measured } \\
\text { Stress (psi) }\end{array}$ \\
\hline Item 1 & Station 15 & Subgrade & 3.72 & 5.52 & 11.24 & 7.7 & 6.3 & $\begin{array}{l}\text { vs. } \\
\text { Predicted } \\
\text { (psi) }\end{array}$ \\
\hline Item 1 & Station 28 & Subgrade & 3.24 & 5.76 & 11.00 & 8.2 & 7.6 & -0.6 \\
\hline Item 1 & Station 20 & Base & 3.24 & 6.12 & 5.24 & 32.7 & 33.9 & 1.2 \\
\hline Item 1 & Station 33 & Base & 3.12 & 5.64 & 5.12 & 32.7 & 30.5 & -2.2 \\
\hline Item 2 & Station 15 & Subgrade & 3.24 & 5.60 & 10.84 & 8.3 & 7.3 & -1.0 \\
\hline Item 2 & Station 28 & Subgrade & 3.24 & 5.88 & 11.12 & 8.1 & 13.0 & 4.9 \\
\hline Item 2 & Station 20 & Base & 3.12 & 5.76 & 5.12 & 33.4 & 28.1 & -5.3 \\
\hline Item 2 & Station 33 & Base & 3.36 & 6.12 & 5.36 & 30.9 & 33.1 & 2.2 \\
\hline
\end{tabular}

Dynamic response was measured for approximately 10 minutes of traffic after each designated data collection point to allow for HVS wheel wander and to account for any minor instrumentation misalignments during construction. The response data set were plotted and the maximum pressure reading was selected to represent the response at the designated traffic interval. Collecting data in this manner and selecting the maximum response assisted in ensuring the HVS wheel load was directly over the pressure cell(s). Earth pressure cell response data for the 10-minute test for each designated traffic interval are presented in Appendix A. 
The maximum earth pressure cell response value from each 10-minute test were collected for the subgrade and base course. Changes in the EPC response values installed in the subgrade for Item 1 and Item 2 are shown in Figure 23. Changes in the EPC response values installed in the base course for Item 1 and Item 2 are shown in Figure 24.

Subgrade and base earth pressure cell response values in the stabilized sections were found to be generally equivalent to measured responses in the unstabilized section. A slight upward trend was observed in subgrade pressure with increasing traffic that may be due to densification and stiffening over time.

Figure 23. Peak subgrade earth pressure cell response during trafficking.

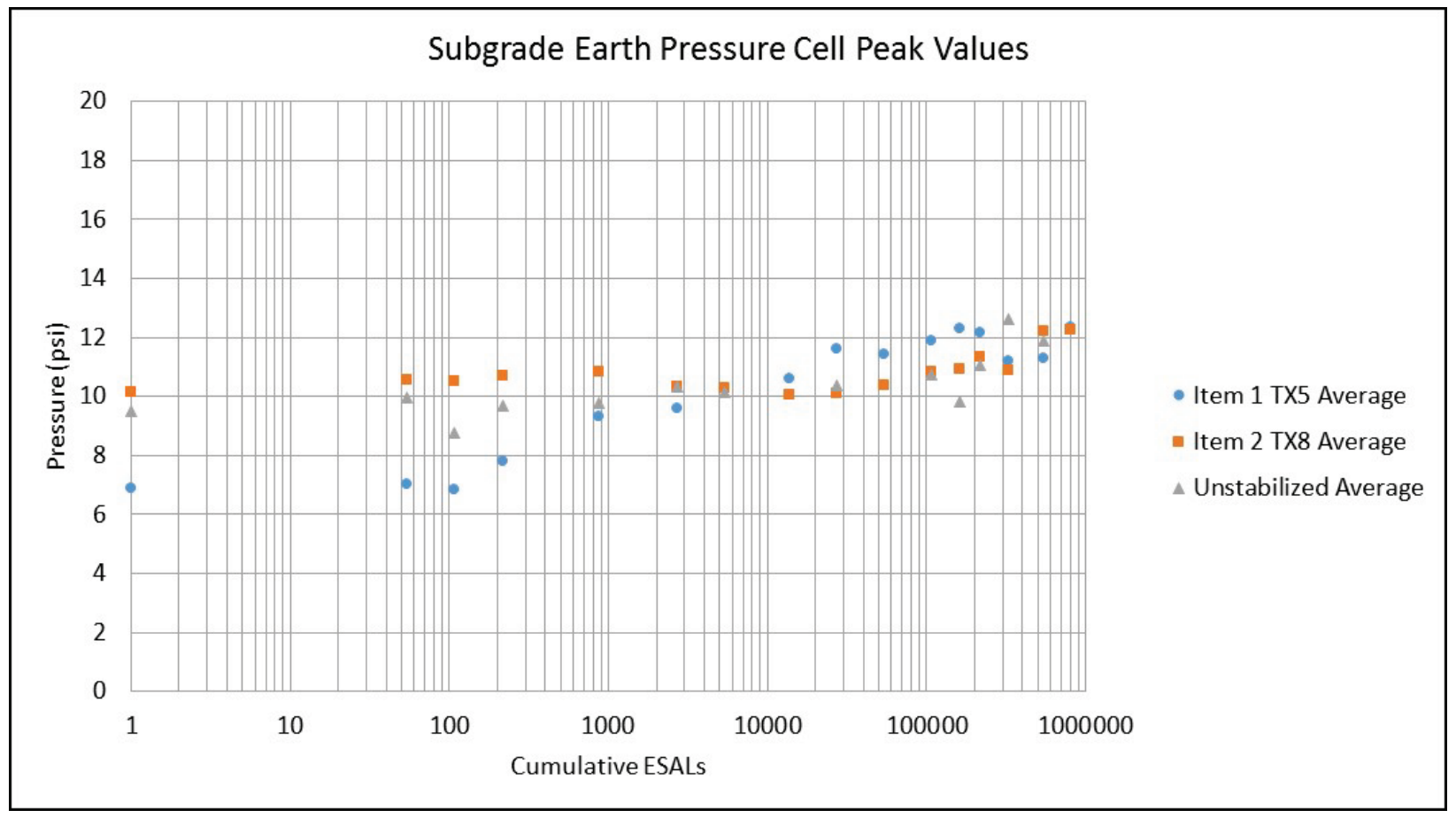


Figure 24. Peak base earth pressure cell response during trafficking.

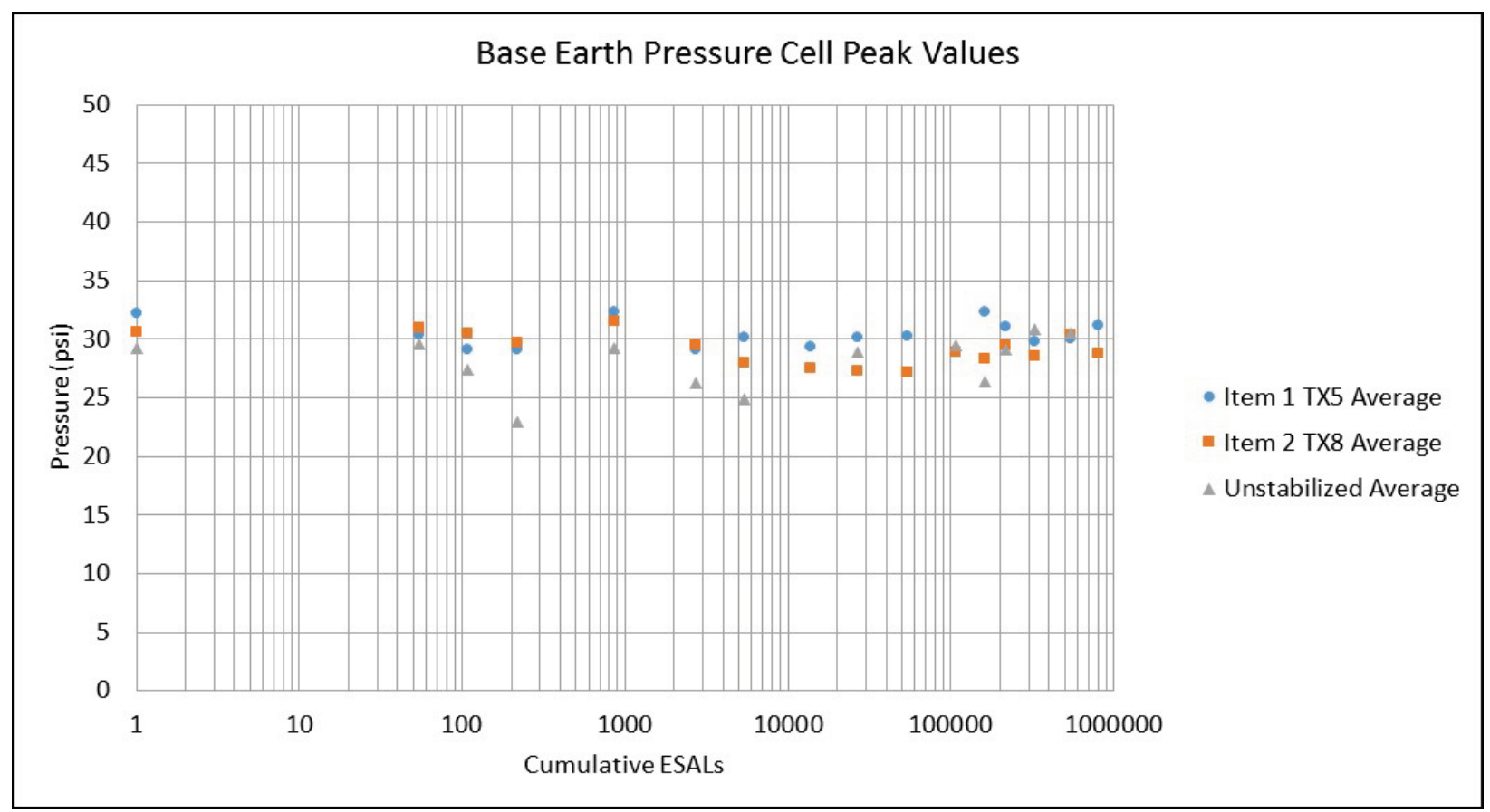

\subsection{Single-depth deflectometers}

Single-depth deflectometers were installed near the center of each test item (approximately Station 24). The gauges had a measurement range of \pm 2 inches and were installed at the top of the subgrade to give an estimate of deflections experienced by the subgrade. Single-depth deflectometer response data for the 10-minute test for each designated traffic interval are presented in Appendix B. Installation depths, predicted deflection values using PSEVEN, and measured deflection values for each test item are presented in Table 7.

Table 7. Predicted and measured single-depth deflectometer responses.

\begin{tabular}{|l|l|l|c|c|c|c|c|c|}
\hline \multicolumn{2}{|c|}{} & $\begin{array}{c}\text { As-built } \\
\text { HMA } \\
\text { Thickness } \\
\text { (in.) }\end{array}$ & $\begin{array}{c}\text { As-built } \\
\text { Base } \\
\text { Thickness } \\
\text { (in.) }\end{array}$ & $\begin{array}{c}\text { SDD depth } \\
\text { from } \\
\text { surface } \\
\text { (in.) }\end{array}$ & $\begin{array}{c}\text { Measured } \\
\text { Predicted } \\
\text { deflection(in.) }\end{array}$ & $\begin{array}{c}\text { Measured } \\
\text { vs. } \\
\text { deflection } \\
\text { (in.) }\end{array}$ & $\begin{array}{c}\text { Predicted } \\
\text { (in.) }\end{array}$ \\
\hline Item 1 & Station 24 & Subgrade & 3.12 & 5.88 & 11.00 & 0.029849 & 0.021309 & -0.00854 \\
\hline Item 2 & Station 24 & Subgrade & 3.12 & 5.76 & 10.88 & 0.030039 & 0.019779 & -0.01026 \\
\hline
\end{tabular}

Peak deflection values were obtained from the 10-minute test after each designated traffic interval. SDD peak value changes with traffic are shown in Figure 25. Measured deflections in the stabilized items were approximately $1 / 2$ of that observed in the unstabilized section. This may be indicative of base stiffening due to aggregate interlock at the geogrid/aggregate interface. 
Figure 25. Peak subgrade deflection during trafficking.

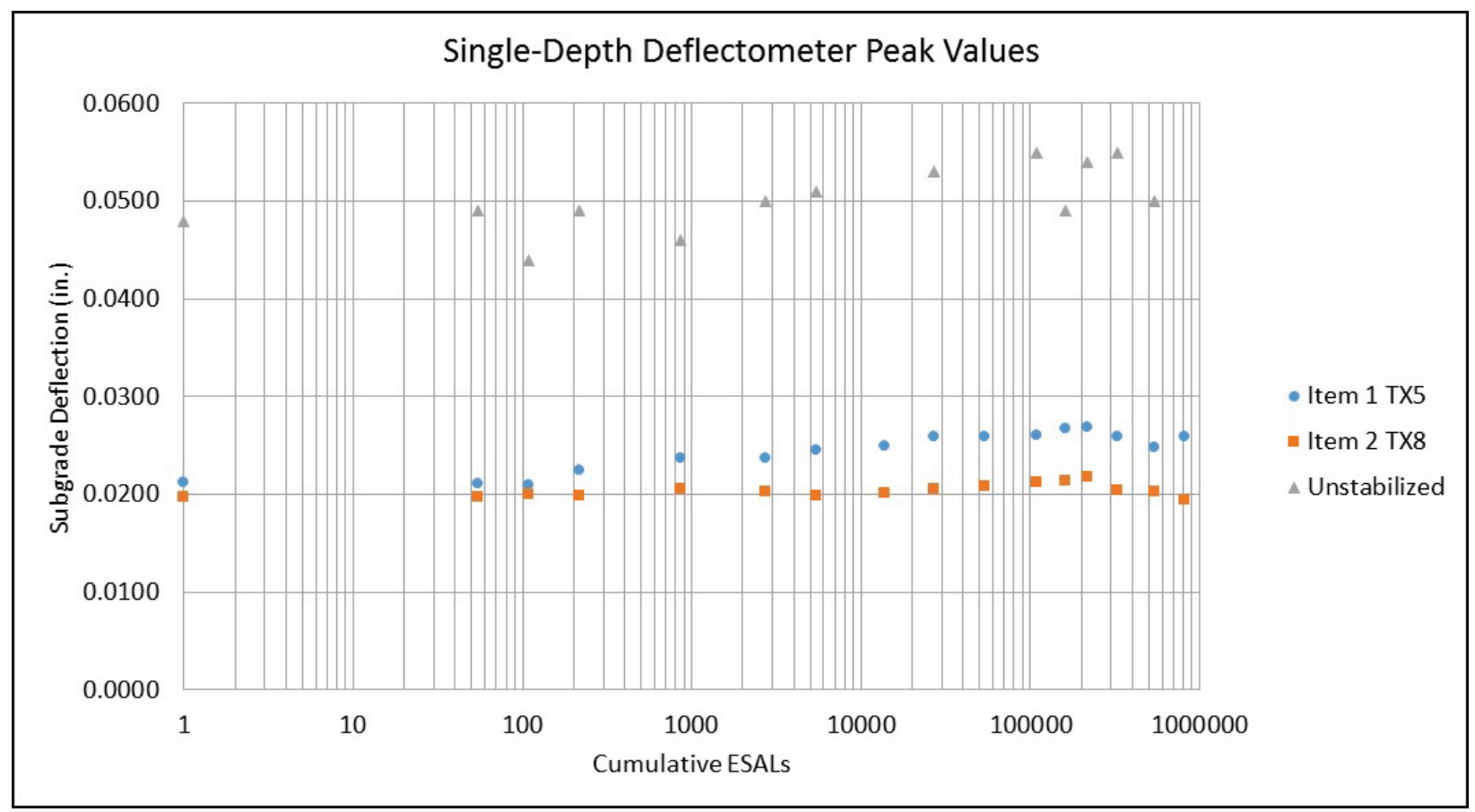

It is noted that the measured deflection values were lower than the PSEVEN predicted values in both test items, a possible indication of base course stiffening provided by the geogrids.

\subsection{Asphalt strain gauges}

Asphalt strain gauges (ASGs) were installed at Stations 12.5 and 37 in each item for this study. Two strain gauges were placed at each location with one oriented in the transverse direction and one oriented in the longitudinal direction. Response data were collected for a 10-minute interval at each designated data collection point, as with all other instrumentation. Dynamic asphalt strain response data are presented in Appendix C. Installation depths, predicted strain values, and measured strain values are presented in Table 8. Peak tensile strain response values are presented in Figure 26. It is noted that the measured peak tensile strain responses for the unstabilized section were much higher than that measured in the stabilized sections. This phenomena was not anticipated as higher peak strain values were expected with a 1 in. reduction in asphalt thickness. Different asphalt strain gauges were utilized for this study due to construction survivability concerns identified in previous work. It is believed the difference in gauge manufacturer could be a cause of the observed peak asphalt strain gauge responses. It is recommended caution be exercised when comparing these data. 
Table 8. Predicted and measured asphalt strain gauge responses.

\begin{tabular}{|c|c|c|c|c|c|c|c|c|}
\hline \multicolumn{3}{|c|}{ Location/Orientation } & $\begin{array}{c}\text { As-built } \\
\text { HMA } \\
\text { Thickness } \\
\text { (in.) }\end{array}$ & $\begin{array}{c}\text { As-built } \\
\text { Base } \\
\text { Thickness } \\
\text { (in.) }\end{array}$ & $\begin{array}{l}\text { ASG depth } \\
\text { from } \\
\text { surface (in.) }\end{array}$ & $\begin{array}{l}\text { Predicted } \\
\text { Microstrain } \\
\text { (x 10-6 } \\
\text { in./in.) }\end{array}$ & $\begin{array}{l}\text { Measured } \\
\text { Microstrain } \\
\text { (x 10-6 } \\
\text { in./in.) }\end{array}$ & $\begin{array}{l}\text { Measured } \\
\text { vs. Predicted } \\
\text { (x 10-6 } \\
\text { in./in.) }\end{array}$ \\
\hline Item 1 & Station 12.5 & Transverse & 3.36 & 5.94 & 3.36 & 216 & 158 & -58 \\
\hline Item 1 & Station 12.5 & Longitudinal & 3.36 & 5.94 & 3.36 & 263 & 250 & -13 \\
\hline Item 1 & Station 37 & Transverse & 2.88 & 5.88 & 2.88 & 228 & 167 & -61 \\
\hline Item 1 & Station 37 & Longitudinal & 2.88 & 5.88 & 2.88 & 269 & 260 & -9 \\
\hline Item 2 & Station 12.5 & Transverse & 3.30 & 5.58 & 3.30 & 222 & 146 & -76 \\
\hline Item 2 & Station 12.5 & Longitudinal & 3.30 & 5.58 & 3.30 & 269 & 175 & -94 \\
\hline Item 2 & Station 37 & Transverse & 3.36 & 6.24 & 3.36 & 213 & 153 & -60 \\
\hline Item 2 & Station 37 & Longitudinal & 3.36 & 6.24 & 3.36 & 259 & 143 & -116 \\
\hline
\end{tabular}

Figure 26. Peak asphalt tensile strain during trafficking.

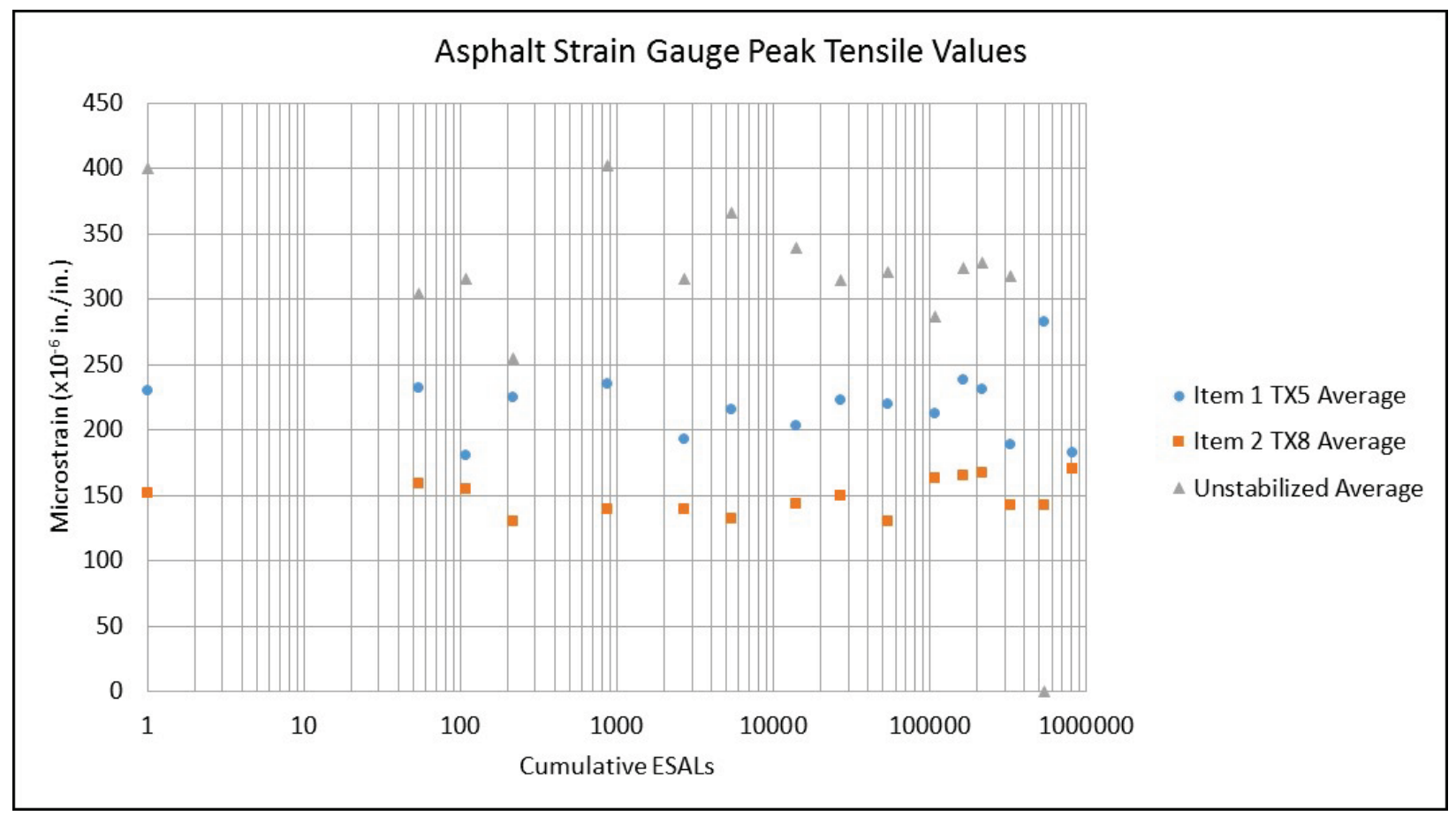




\section{Post-Traffic Forensics}

After the conclusion of traffic testing, each test item was trenched in two locations to investigate the method of pavement failure and characterize material properties. Trench locations were selected to correspond with the locations of minimum and maximum rutting in each item, as determined by review of both the rutting and surface deformation data. Each trench was approximately $3 \mathrm{ft}$ wide and extended across the full traffic lane. Excavation began by saw cutting the HMA surface and carefully removing it to avoid disturbing the underlying base course. Measurements of each layer thickness were made at each trench location. In-field CBR tests, nuclear density measurements, and moisture content determinations were performed on each layer both within the wheel path and outside the wheel path. Results of tests performed in the trench locations for each item are shown in Table 9.

Table 9. Post-traffic physical data.

\begin{tabular}{|c|c|c|c|}
\hline Property & $\begin{array}{c}\text { Item } 1 \\
\text { TX5 Stabilized Base }\end{array}$ & $\begin{array}{c}\text { Item } 2 \\
\text { TX8 Stabilized Base }\end{array}$ & $\begin{array}{c}\text { Control } \\
\text { 4-in. Nominal AC } \\
\text { Unstabilized Base } \\
\text { (Norwood and } \\
\text { Tingle 2014) }\end{array}$ \\
\hline \multicolumn{4}{|c|}{ CH Subgrade Properties } \\
\hline Wet Density (pcf) & 116.9 & 117.9 & 113.9 \\
\hline Dry Density (pcf) & 89.1 & 89.1 & 88.6 \\
\hline $\begin{array}{l}\text { Nuclear Moisture Content } \\
(\%)\end{array}$ & 31.2 & 32.3 & 28.1 \\
\hline Oven-Dried Moisture (\%) & 32.7 & 32.3 & 30.1 \\
\hline In-Place CBR (\%) & 11.1 & 9.8 & 11.0 \\
\hline \multicolumn{4}{|c|}{ Crushed Limestone Properties } \\
\hline Wet Density (pcf) & 140.5 & 142.6 & ** \\
\hline Dry Density (pcf) & 136.7 & 138.7 & ** \\
\hline $\begin{array}{l}\text { Nuclear Moisture Content } \\
(\%)\end{array}$ & 2.8 & 2.9 & ** \\
\hline Oven-Dried Moisture (\%) & 2.2 & 1.7 & $\star *$ \\
\hline In-Place CBR (\%) & $100+$ & $100+$ & ** \\
\hline
\end{tabular}

**Values not reported due to base disturbance during excavation 
The test results indicate there was a minor increase in dry density of the subgrade, while the moisture content was relatively constant. A $2.2 \mathrm{pcf}$ increase was measured in the base course dry density for Item 1 and a $1.5 \mathrm{pcf}$ increase in base course density was measured for Item 2. Base course moisture contents for Items 1 and 2 decreased by $0.8 \%$ and $1.5 \%$, respectively. An increase in subgrade CBR in the wheelpath was observed in both test sections, which was found to be consistent with observations made by Norwood and Tingle (2014).

The base course was carefully excavated to expose the underlying geogrid for visual inspection as shown in Figure 27 and Figure 28. Visual investigation revealed indentations were present in the subgrade of both test items (Figure 29 and Figure 30), indicating aggregate strike-through and interlock with the geogrid. Visual inspection indicated the geogrid was intact and no damage was sustained during construction or trafficking.

Visual inspection of the subsurface layers was performed to determine rutting behavior in each test section. The excavated areas are shown in Figure 31 through Figure 33 with orange markers used to delineate each layer interface. No significant permanent deformation was observed in the subgrade of both test items. Visual inspection indicated that the accumulated deformation was limited to the HMA and base-course layers.

Figure 27. Item 1 excavated geogrid.

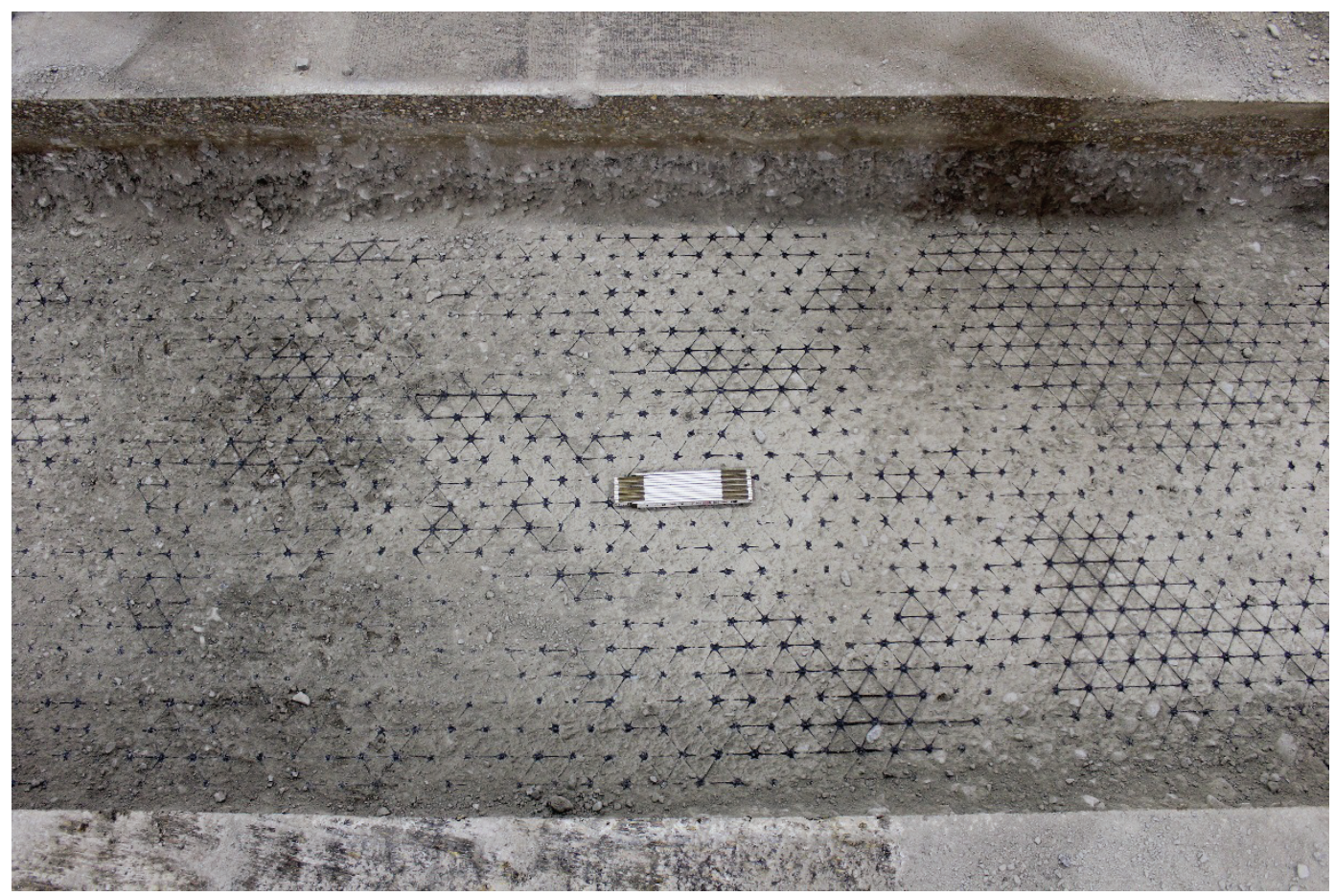


Figure 28. Item 2 excavated geogrid.

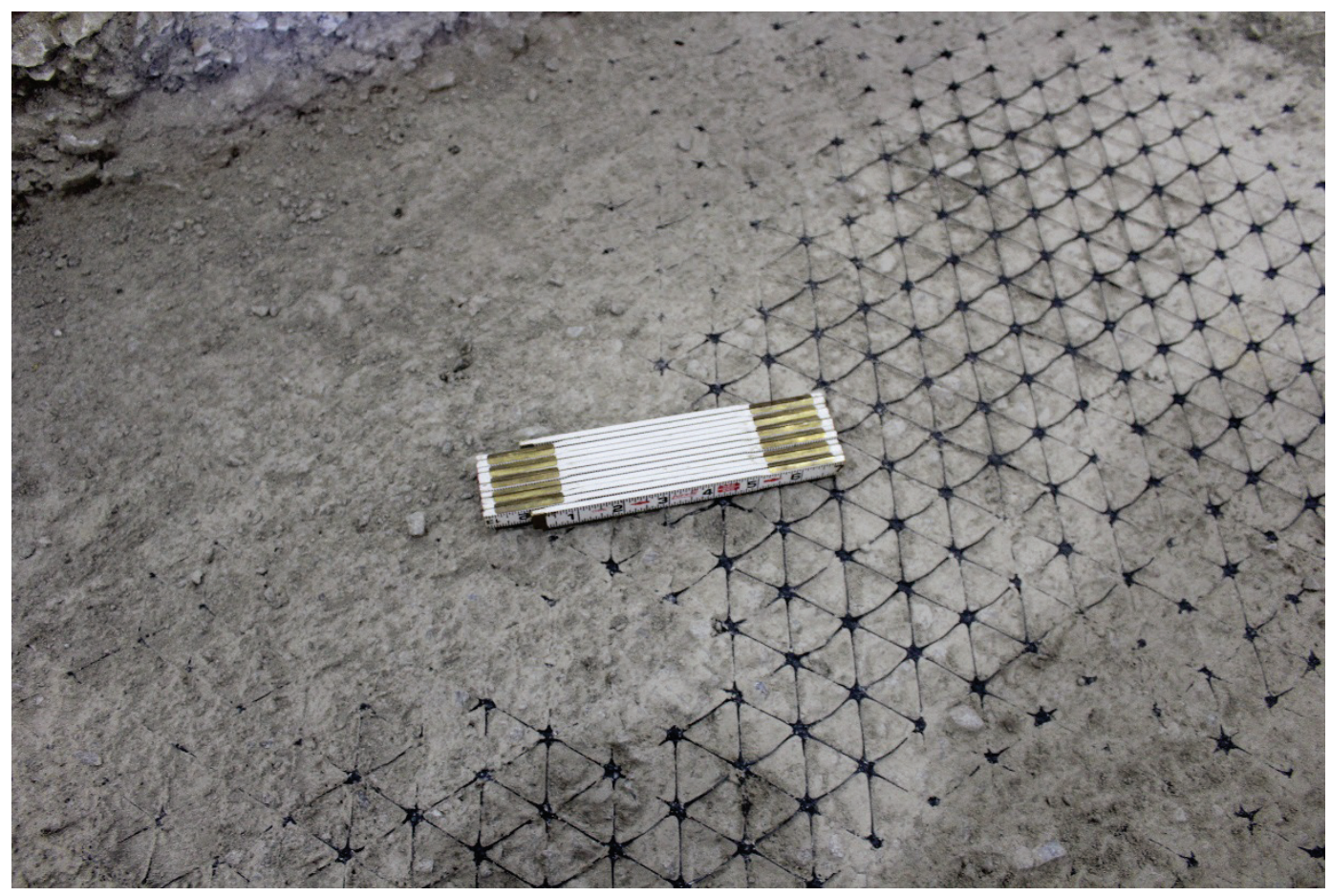

Figure 29. Item 1 indentations in subgrade.

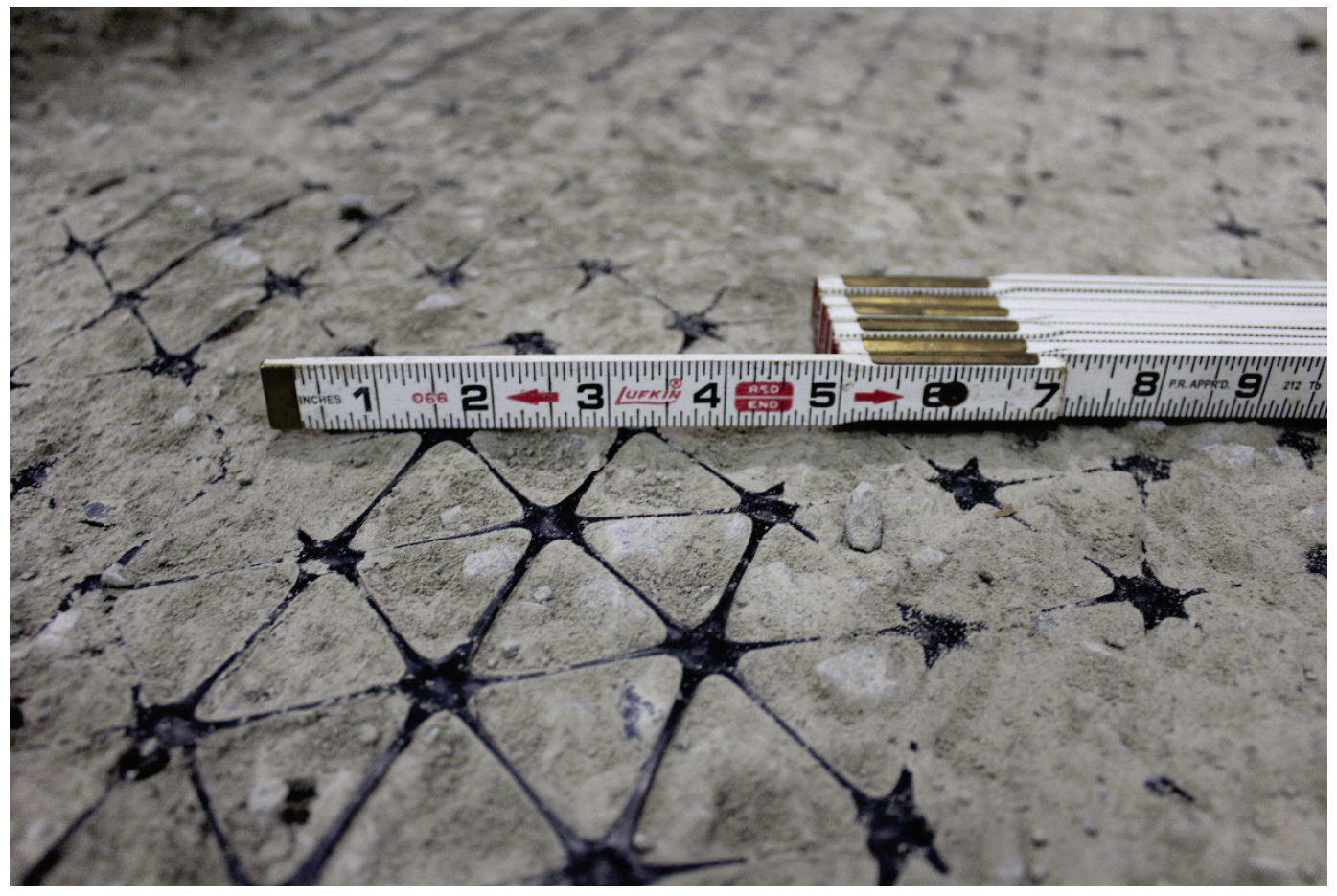


Figure 30. Item 2 indentations in subgrade.

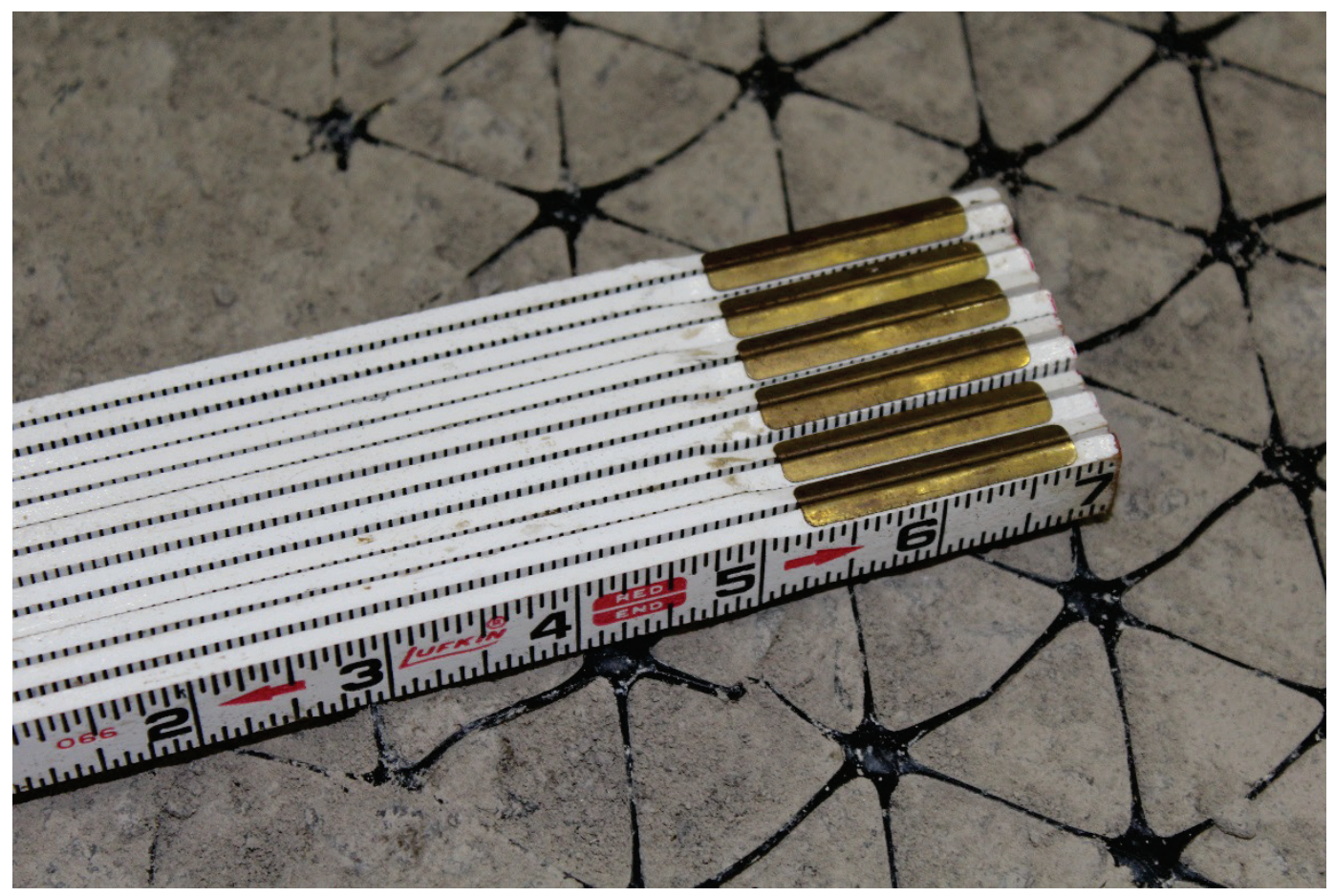

Figure 31. Post-traffic pavement cross section in Item 1.

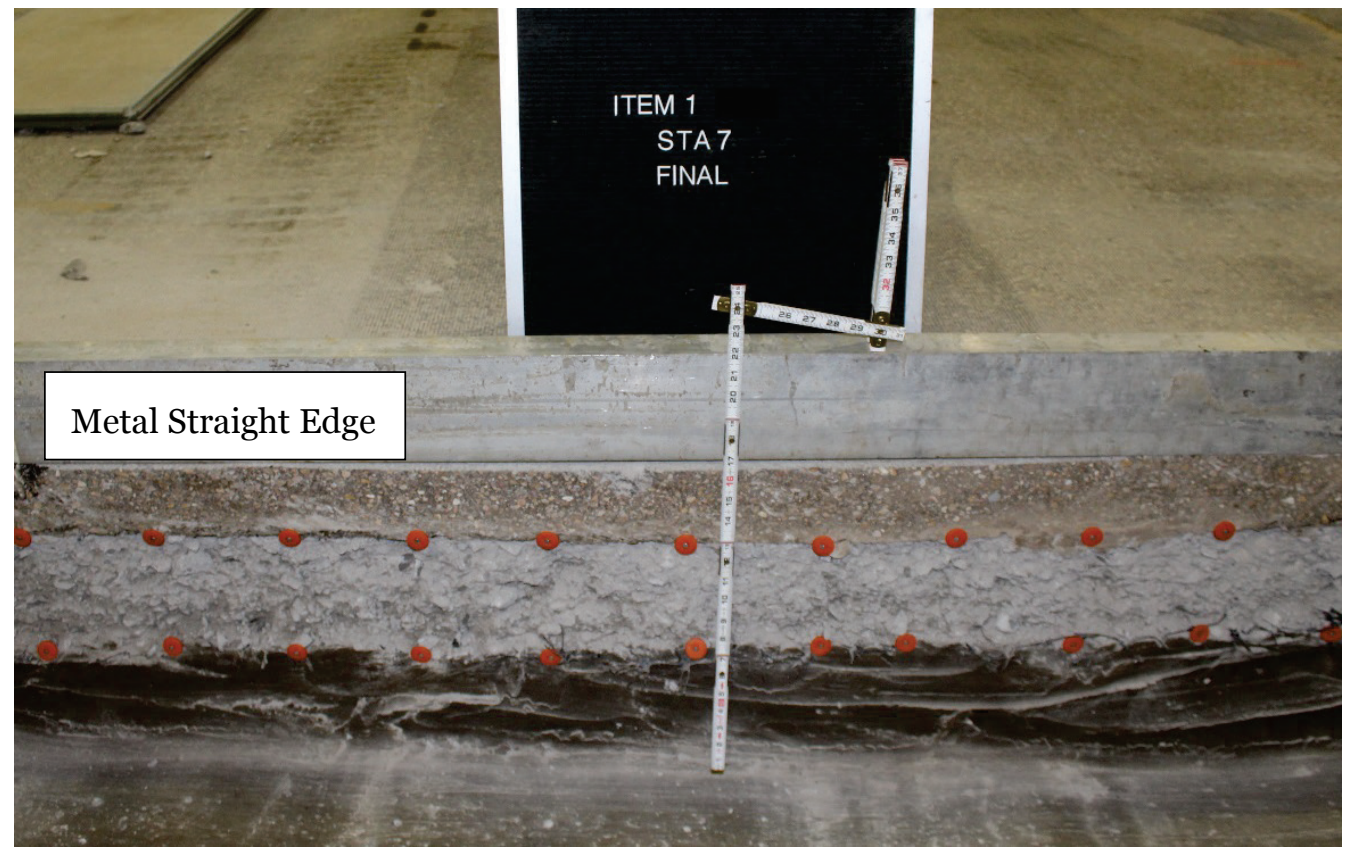


Figure 32. Post-traffic pavement cross section in Item 2.

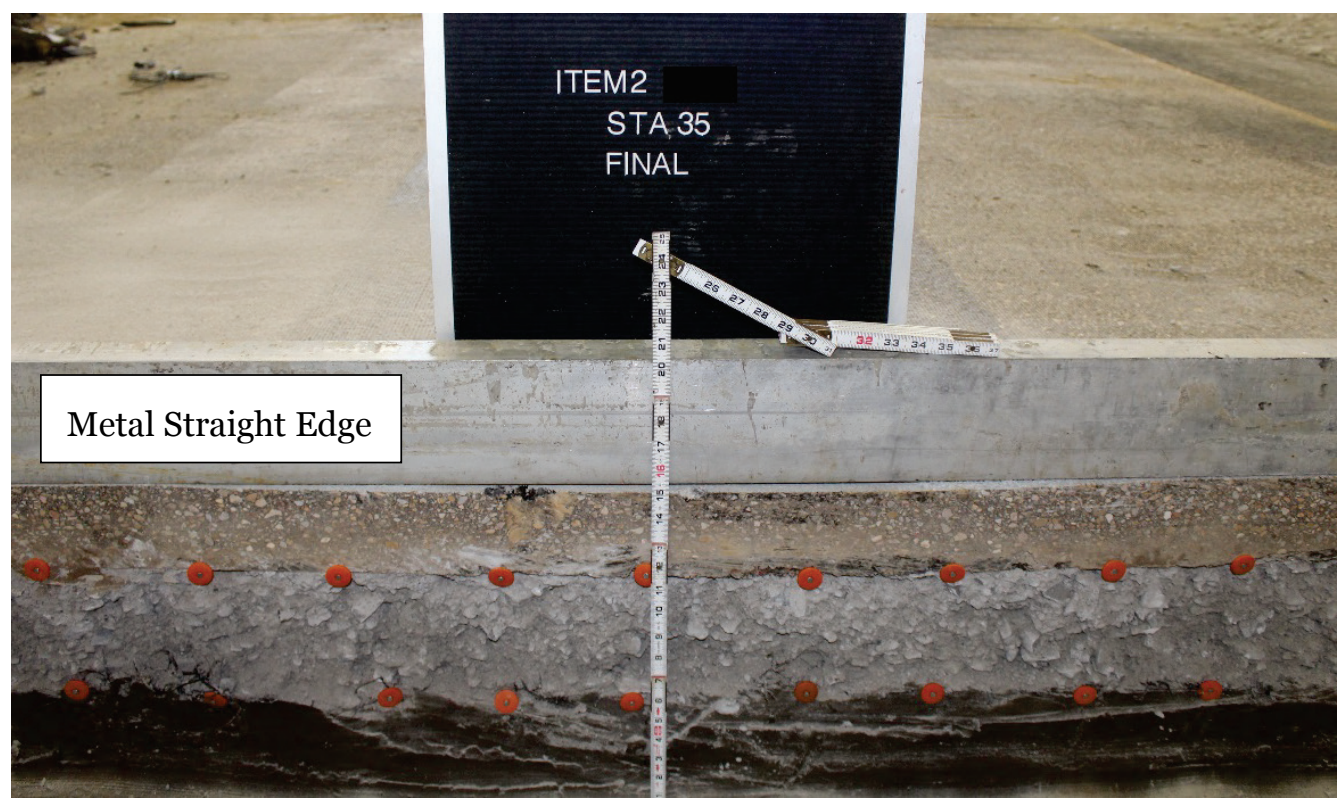

Figure 33. Post-traffic pavement cross section in unstabilized section.

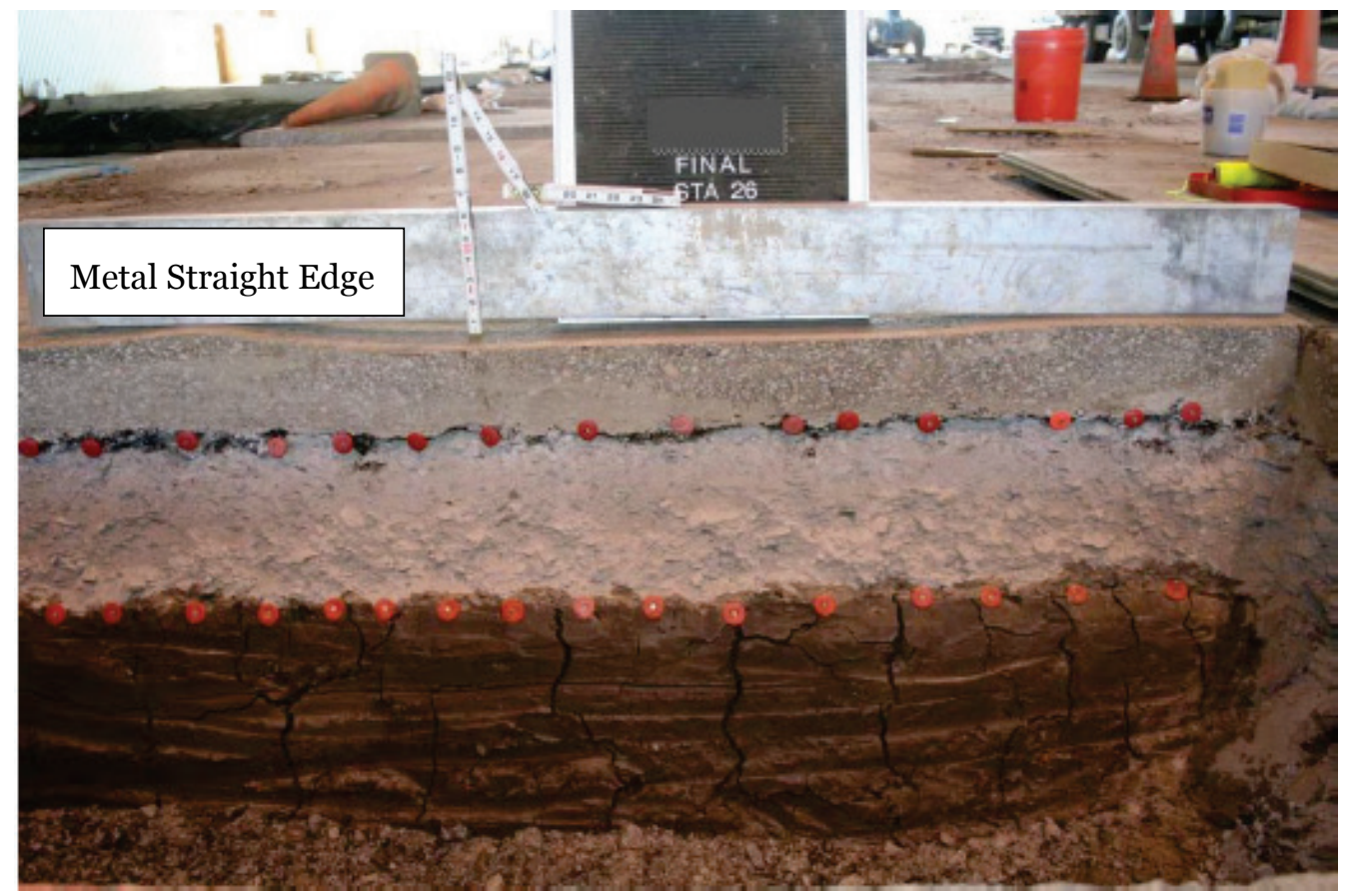




\section{Analysis}

In order to provide a measure of the performance benefit of each geogrid, an analysis was performed to calculate the effective structural number of the stabilized and unstabilized test items. The analysis results are discussed in the following paragraph.

In order to quantify the structural contribution of the geogrid, an effective structural number was calculated using the AASHTO Pavement Design Guide (1993). The effective structural number was calculated using the applied ESALs and the as-built layer thicknesses to compute the structural coefficient of the base-course layer. The effective structural coefficient provides a means of comparing test sections of varying layer thicknesses. Table 10 summarizes the effective base coefficient for each test section. A $90 \%$ reliability and an asphalt structural coefficient of 0.44 was selected for the calculations. The calculations indicate the different geogrid items had nearly the same effective structural coefficient, with both items displaying a significant increase in structural capacity over the unstabilized control item. It should be noted that none of the test sections reached the failure criteria ( 1 in. of rutting); therefore, the structural coefficients presented should be considered conservative estimates.

Table 10. Effective stabilized layer structural coefficient.

\begin{tabular}{|l|l|l|l|}
\hline & Item 1 & Item 2 & Unstabilized \\
\hline Design Base Thickness (in.) & 6 & 6 & 8 \\
\hline Design Asphalt Thickness (in.) & 3 & 3 & 4 \\
\hline Unstabilized Design Structural Number & 2.16 & 2.16 & 2.88 \\
\hline As-Built Base Thickness (in.) & 5.8 & 5.9 & 7.7 \\
\hline As-Built Asphalt Thickness (in.) & 3.20 & 3.22 & 4 \\
\hline Unstabilized As-Built Structural Number & 2.22 & 2.24 & 2.84 \\
\hline Passes to 1-in. rutting (ESALs) & $811,200+$ & $811,200+$ & $811,200+$ \\
\hline Effective Structural Number & $3.08+$ & $3.08+$ & $3.08+$ \\
\hline Effective Base Coefficient (1-in. rutting) & $0.29+$ & $0.28+$ & $0.17+$ \\
\hline Passes to 1/2-in. rutting (ESALs) & $811,200+$ & $811,200+$ & 500,000 \\
\hline Effective Structural Number & $3.08+$ & $3.08+$ & 2.86 \\
\hline Effective Base Coefficient (1/2-in. rutting) & $0.29+$ & $0.28+$ & 0.14 \\
\hline
\end{tabular}




\section{Conclusions and Recommendations}

A full-scale test section was constructed and trafficked to evaluate the performance of geogrid-stabilized highway pavements. The construction and traffic data were analyzed to assess both the relative performance of two multi-axial geogrid stabilized pavement sections and their performance as compared to an unstabilized pavement section from a previous related study (Norwood and Tingle 2014). The following conclusions are a result of this study:

1. The pavement test sections were constructed in a uniform manner with minor variability utilizing similar material and construction techniques used in previous geosynthetic stabilized test sections. The uniformity of construction and materials allow for meaningful comparisons between test sections to be made.

2. As-built ISM values for the stabilized items were found to be less than those for the unstabilized items, which was expected due to a reduced pavement section.

3. Subgrade and base earth pressure cell response values in the stabilized sections were found to be generally equivalent to measured responses in the unstabilized section. A slight upward trend was observed in subgrade pressure with increasing traffic that may be due to densification and stiffening over time.

4. Measured deflections in the stabilized items were approximately $1 / 2$ of that observed in the unstabilized section. This may be indicative of base stiffening due to aggregate interlock at the geogrid/aggregate interface.

5. Asphalt strain gauge response in the stabilized sections were less than that measured in the unstabilized section, however, differing gauge manufacturers were utilized. It is recommended that caution be exercised when comparing these data.

6. Both geogrid stabilized pavement sections improved the rutting resistance when compared to the unstabilized test section.

7. Minimal differences in rutting performance were observed between the two stabilized test sections.

8. The calculated effective base structural coefficient of the geogrid stabilized pavement sections was higher than the unstabilized structural coefficient, suggesting incorporation of a multi-axial geogrid in a flexible pavement base course provides a significant structural benefit. 


\section{References}

American Society for Testing and Materials (ASTM). 2010. Standard test methods for liquid limit, plastic limit, and plasticity index of soils. Designation: D 4318-10e1. West Conshohocken, PA.

American Society for Testing and Materials (ASTM). 2011. Standard practice for classification of soils for engineering purposes (Unified Soil Classification System). Designation: D 2487-11. West Conshohocken, PA.

American Society for Testing and Materials (ASTM). 2012. Standard test methods for laboratory compaction characteristics of soil using modified effort (56,ooo ftblf/ft3 $\left.\left(2,700 \mathrm{kN}-\mathrm{m} / \mathrm{m}^{3}\right)\right)$. Designation: D 1557-12e1. West Conshohocken, PA.

American Society for Testing and Materials (ASTM). 2016. Standard test method for California Bearing Ratio (CBR) of laboratory-compacted soils. Designation: D 1883-16. West Conshohocken, PA.

American Society for Testing and Materials (ASTM). 2015. Standard test methods for inplace density and water content of soil and soil-aggregate by nuclear methods (shallow depth). Designation: D 6938-15. West Conshohocken, PA.

American Society for Testing and Materials (ASTM). 2009. Standard test method for CBR (California Bearing Ratio) of soils in place. Designation: D 4429-09a. West Conshohocken, PA.

American Society for Testing and Materials (ASTM). 2015. Standard test method for use of the dynamic cone penetrometer in shallow pavement applications. Designation: D 6951/6951M-09. West Conshohocken, PA.

Association of American Highway and Transportation Officials (AASHTO). 2012. Standard specification for classification of soils and soil-aggregate mixtures for highway construction purposes. AASHTO M 145. Washington, DC: Association of American Highway and Transportation Officials.

Association of American Highway and Transportation Officials (AASHTO). 2013. Standard method of test for bulk specific gravity $\left(G_{m b}\right)$ of compacted hot mix asphalt (HMA) using saturated surface-dry specimens. AASHTO T 166. Washington, DC: Association of American Highway and Transportation Officials.

Association of American Highway and Transportation Officials (AASHTO). 1993. AASHTO guide for design of pavement structures. Washington, DC: Association of American Highway and Transportation Officials.

Norwood, G. J., and J. S. Tingle. 2014. Performance of geogrid-stabilized flexible pavements. ERDC/GSL-TR-14-28. Vicksburg, MS: U.S. Army Engineer Research and Development Center.

Webster, S. L., R. H. Grau, and T. P. Williams. 1992. Description and application of dualmass dynamic cone penetrometer. Instruction Report GL-92-3. Vicksburg, MS: U.S. Army Engineer Waterways Experiment Station. 
Webster, S. L., R. W. Brown, and J. R. Porter. 1994. Force projection site evaluation using the electrical cone penetrometer (ECPO) and the dynamic cone penetrometer (DCP). Technical Report GL-94-17. Vicksburg, MS: U.S. Army Engineer Waterways Experiment Station. 


\section{Appendix A: Earth Pressure Cell Responses}
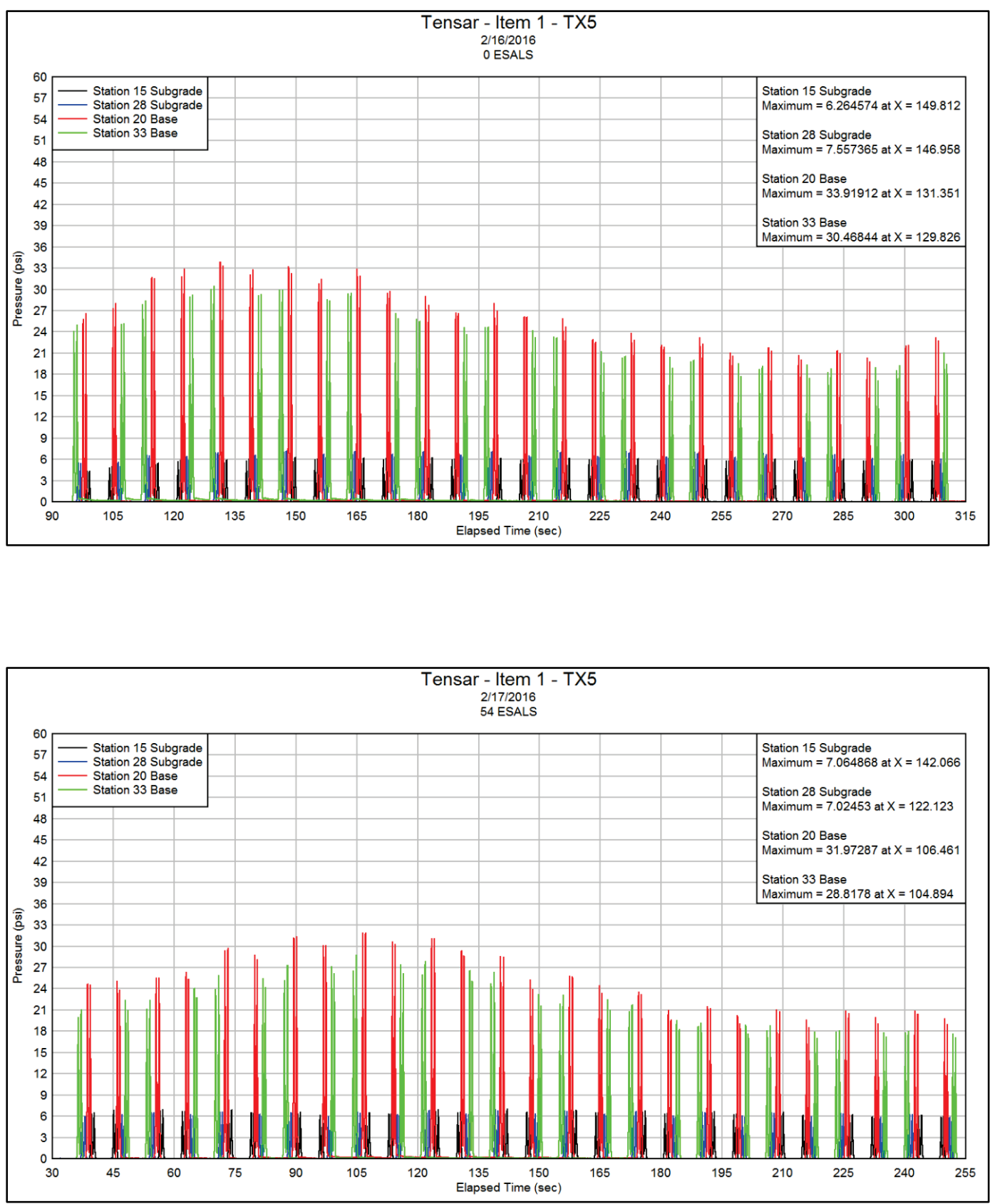

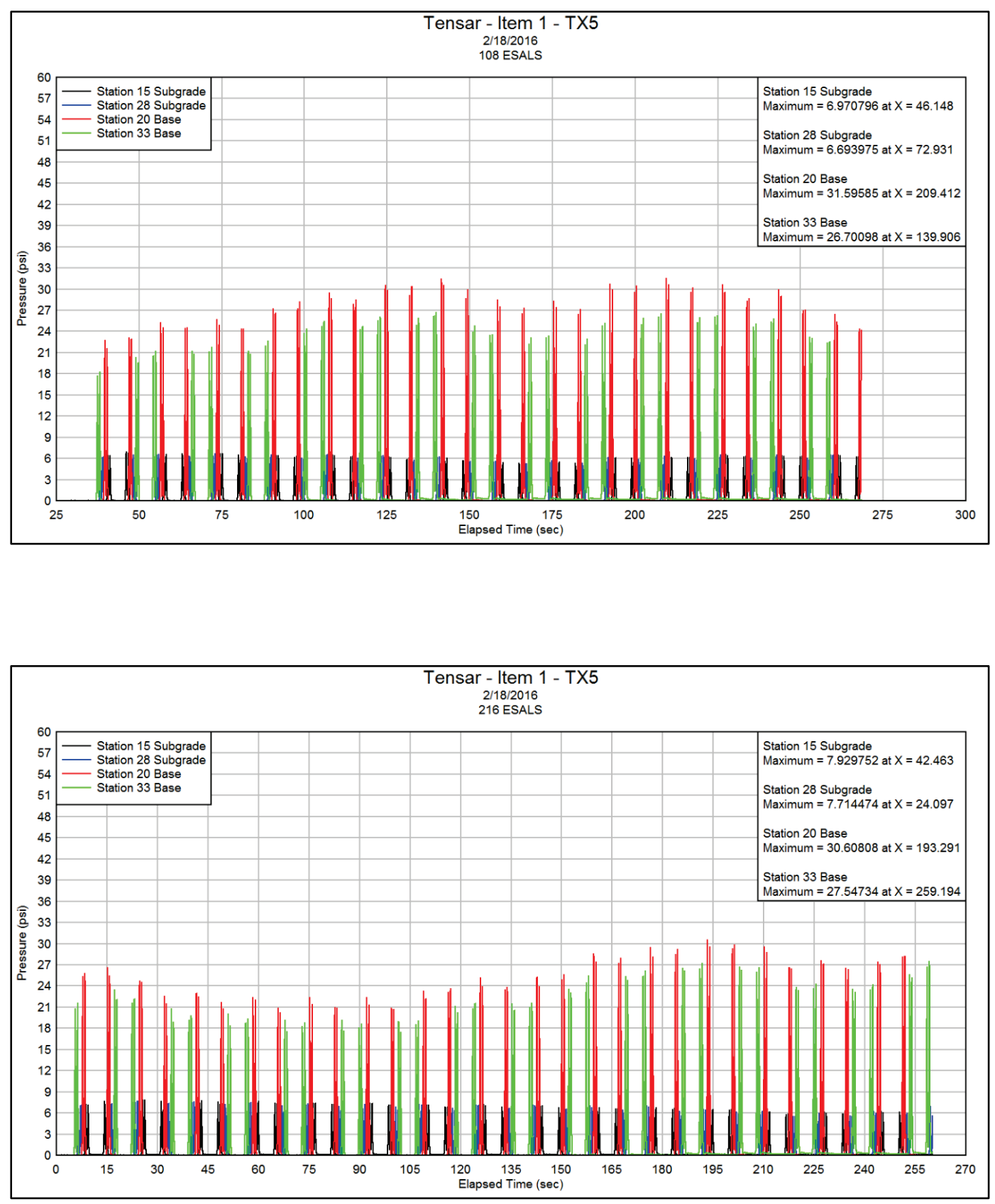

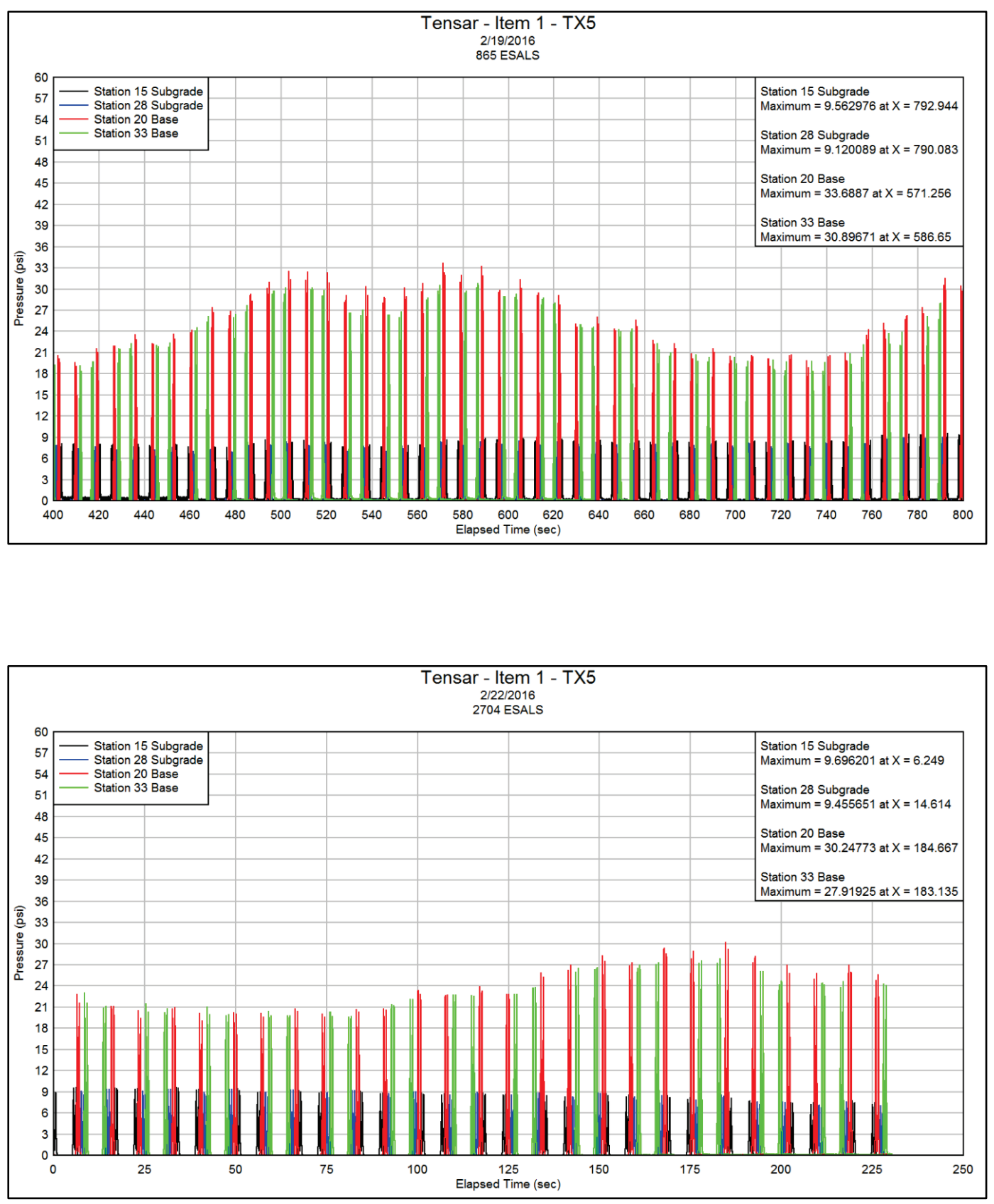

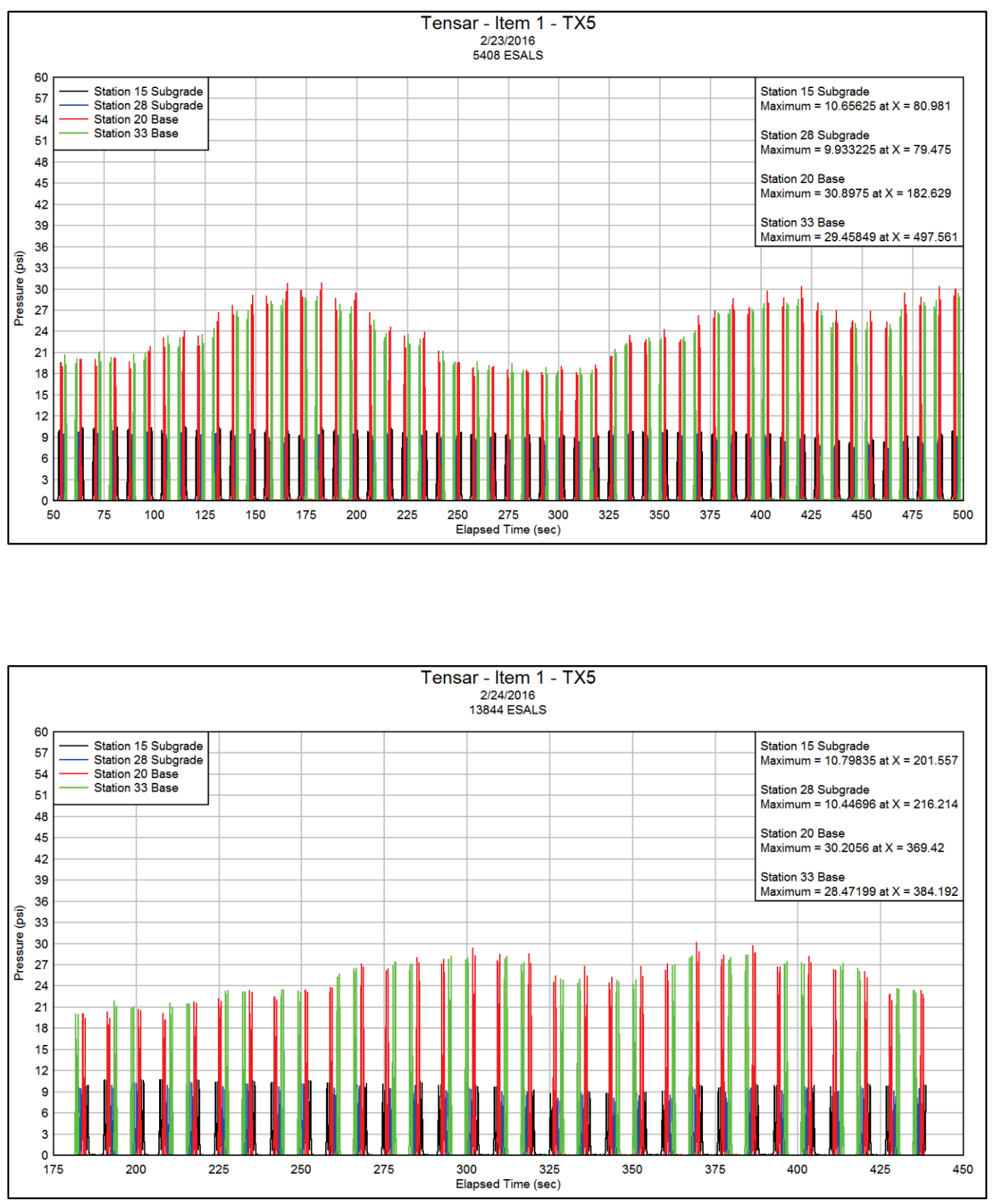

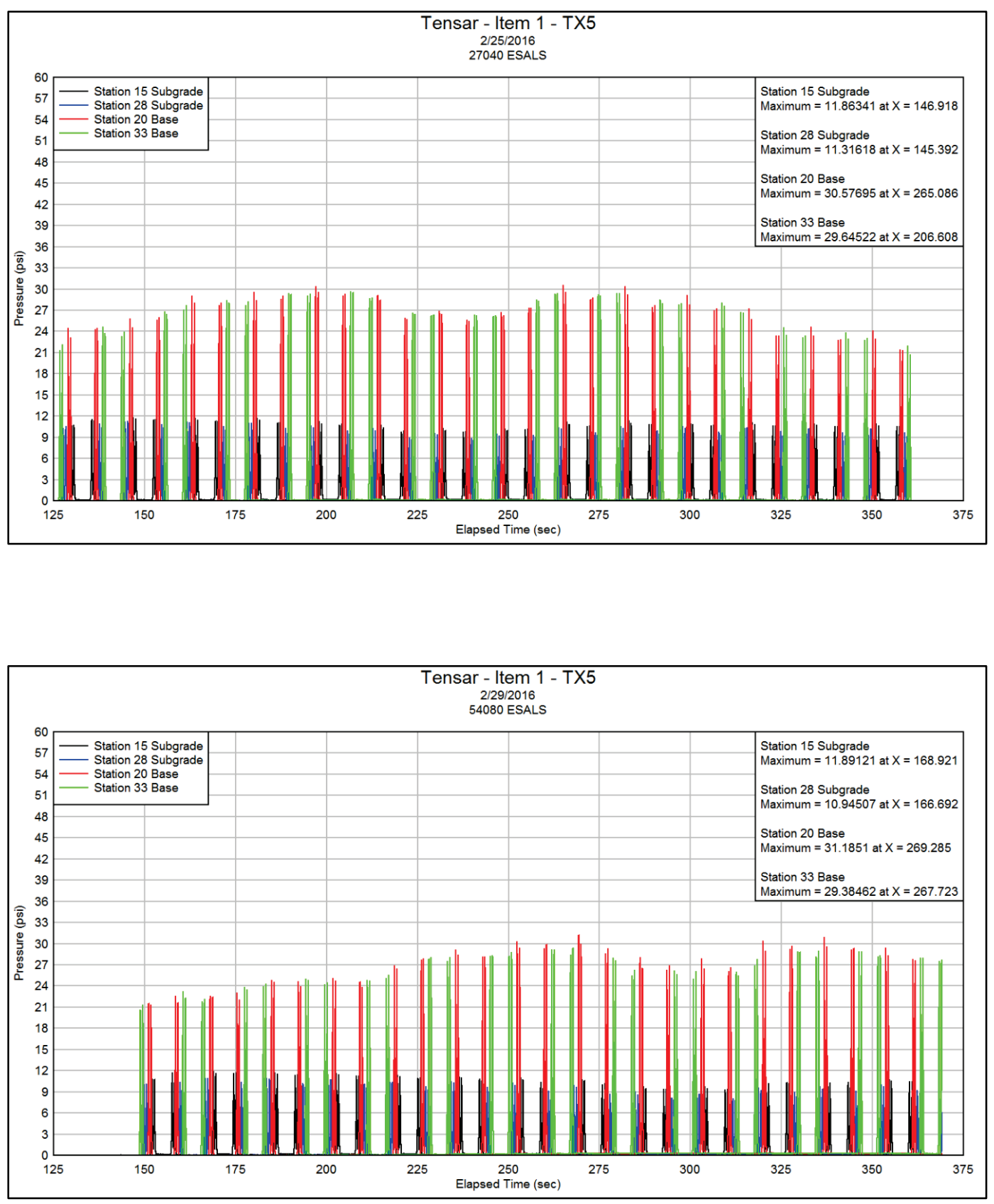

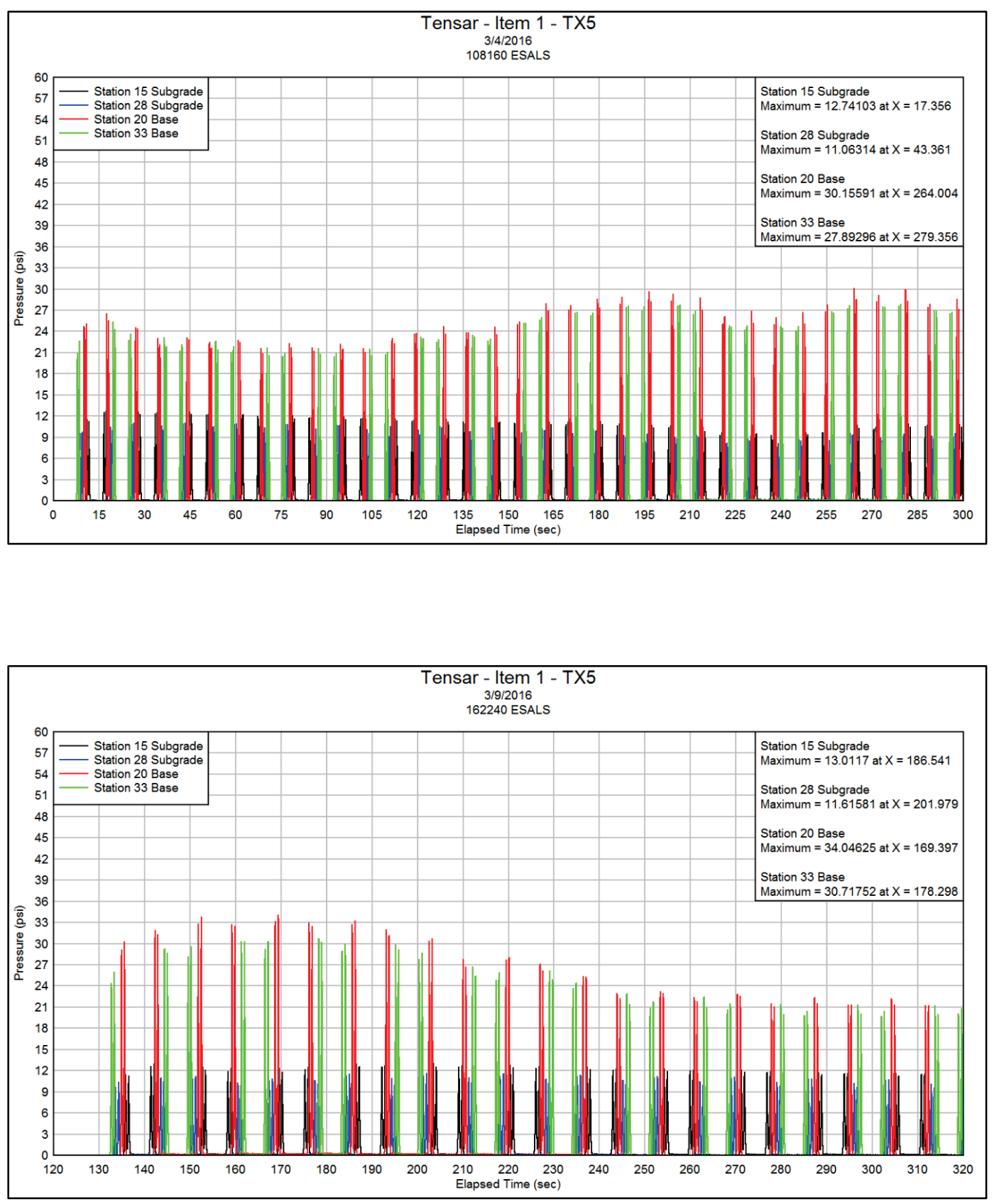

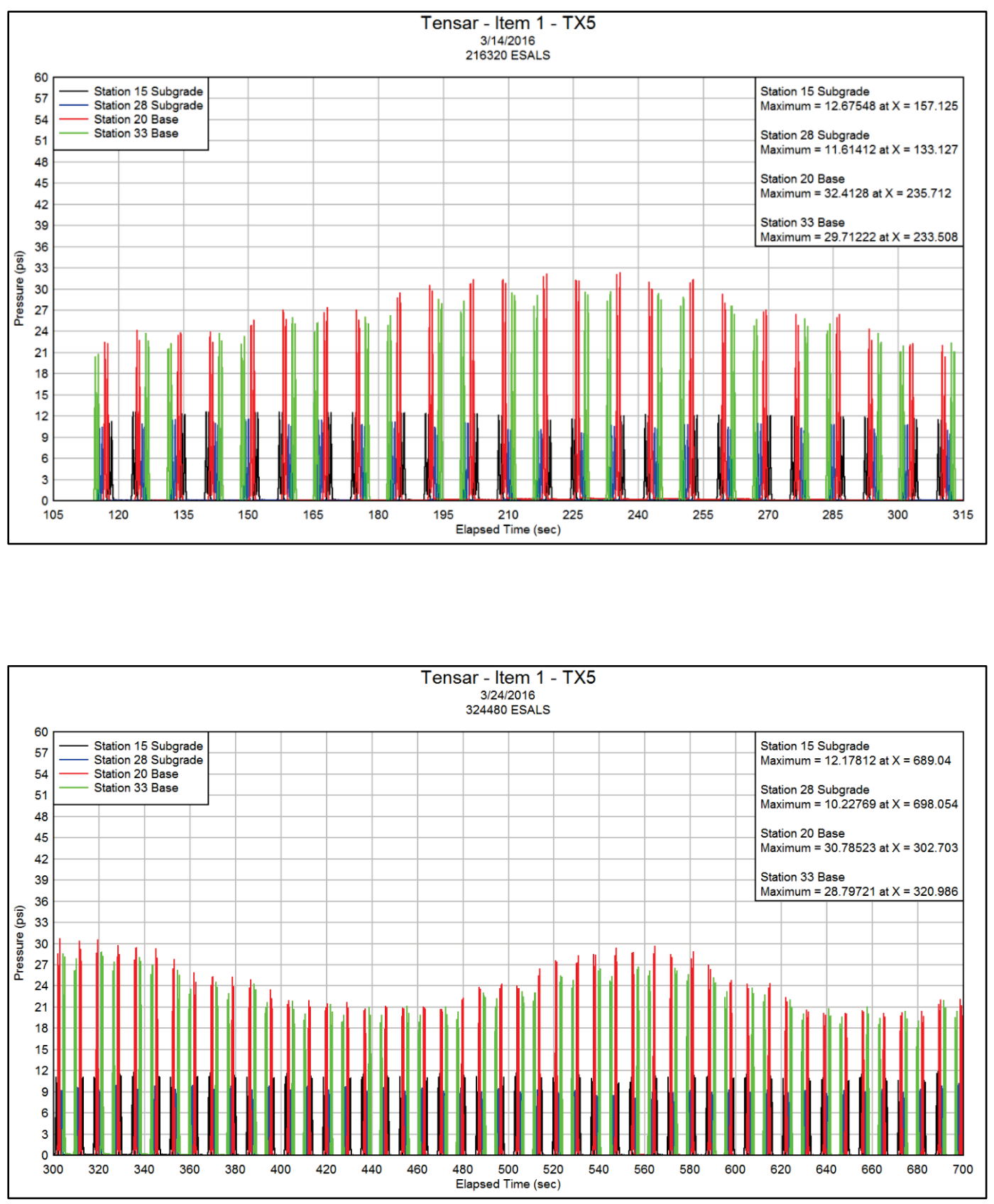

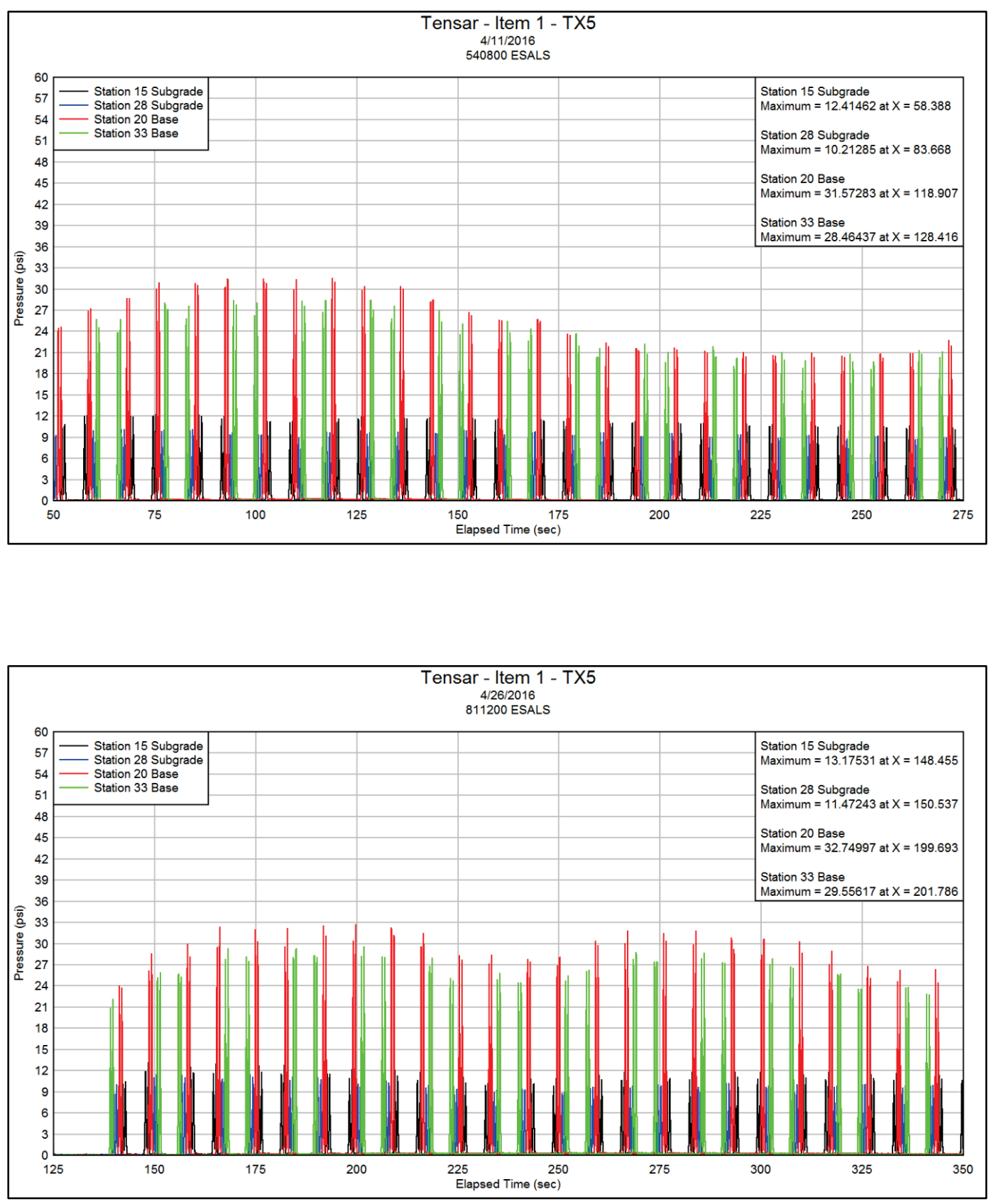

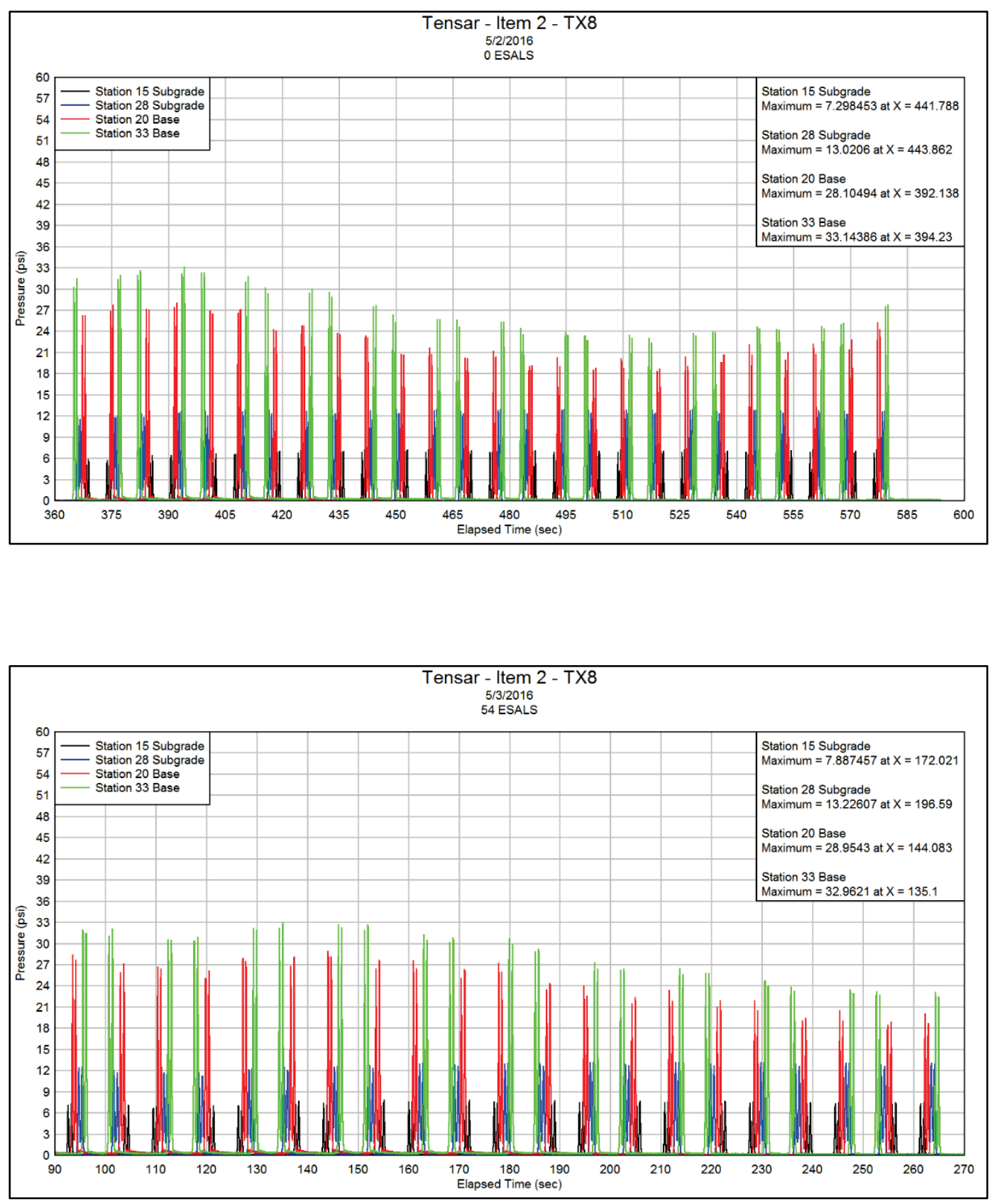

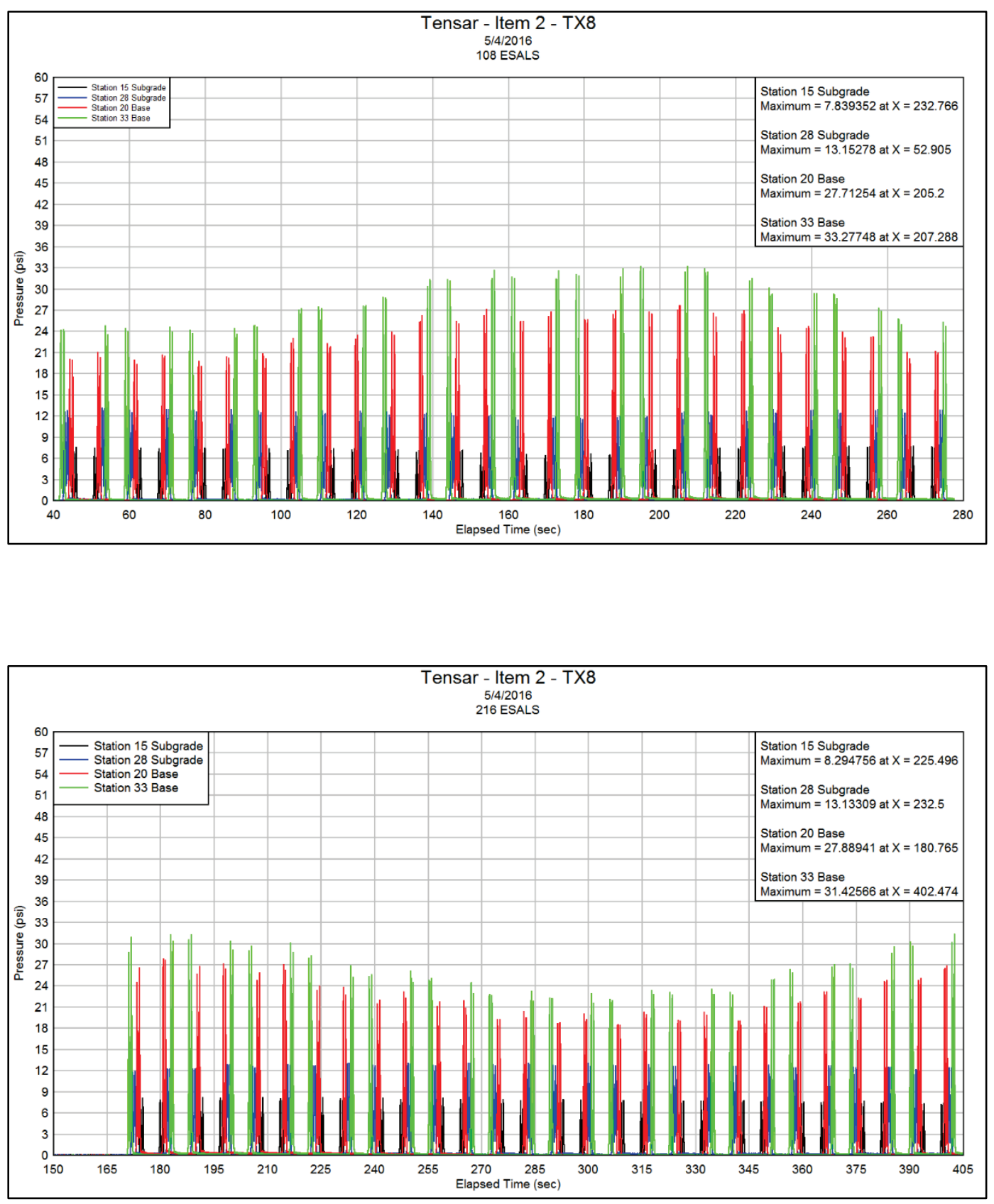

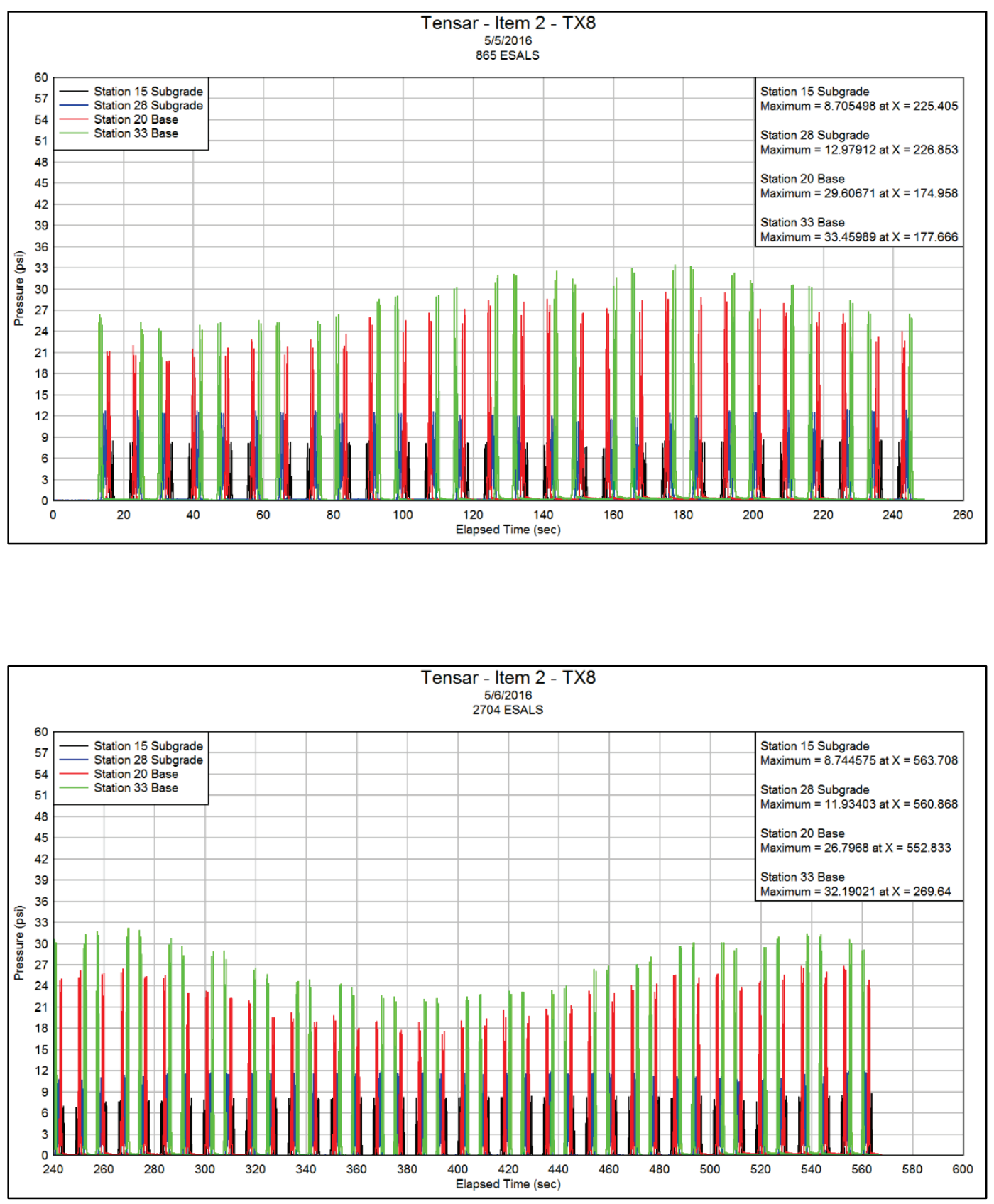

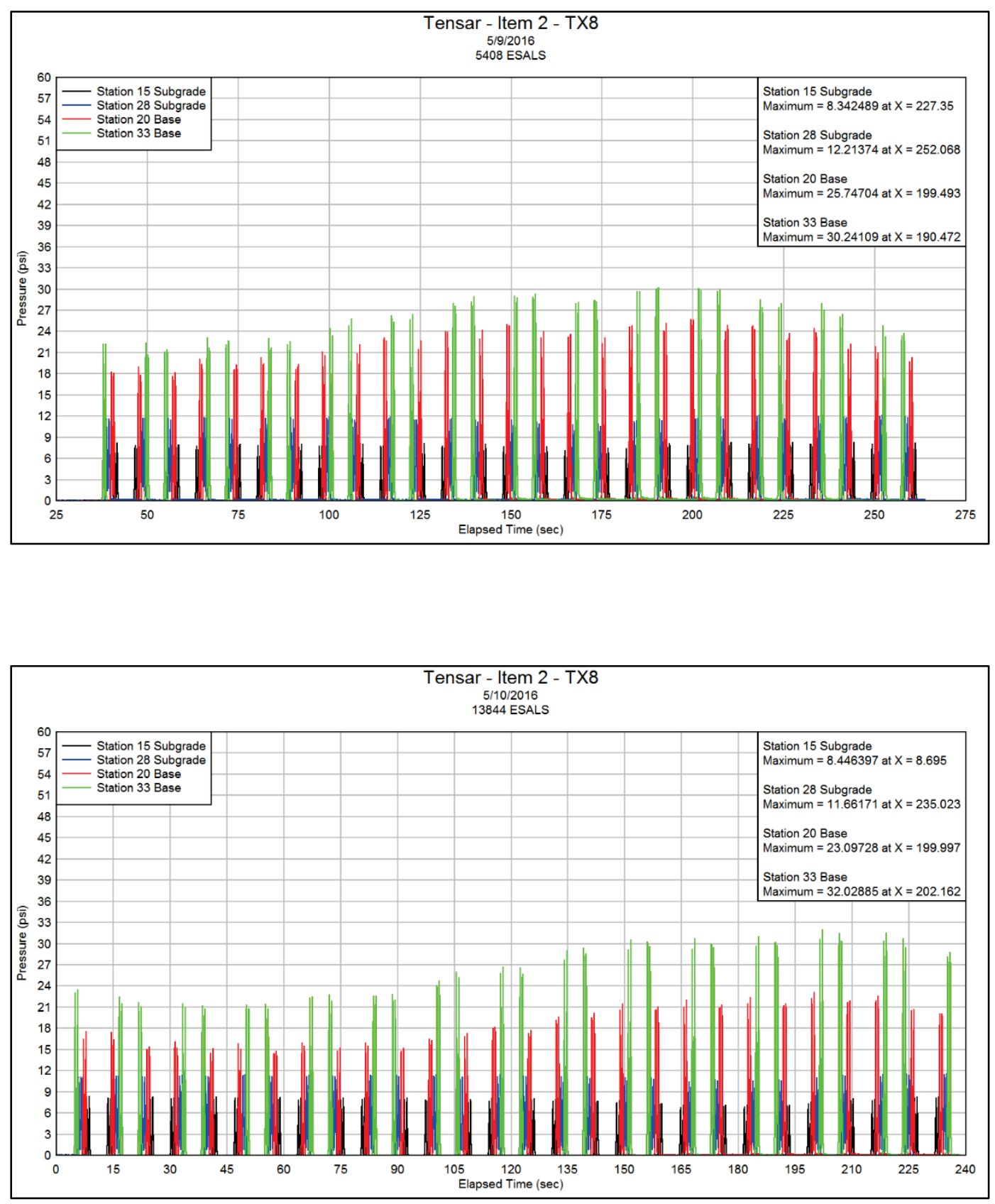

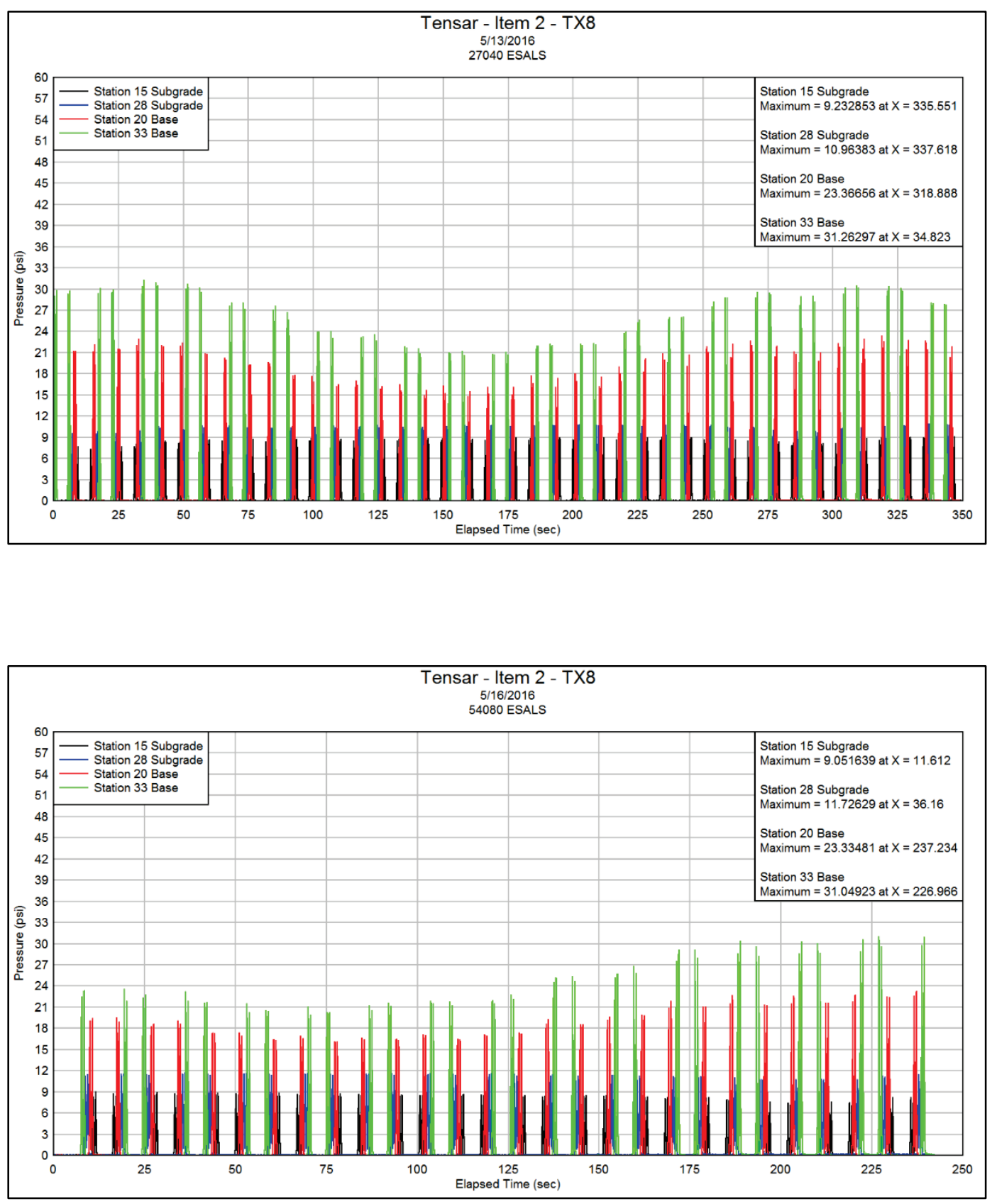

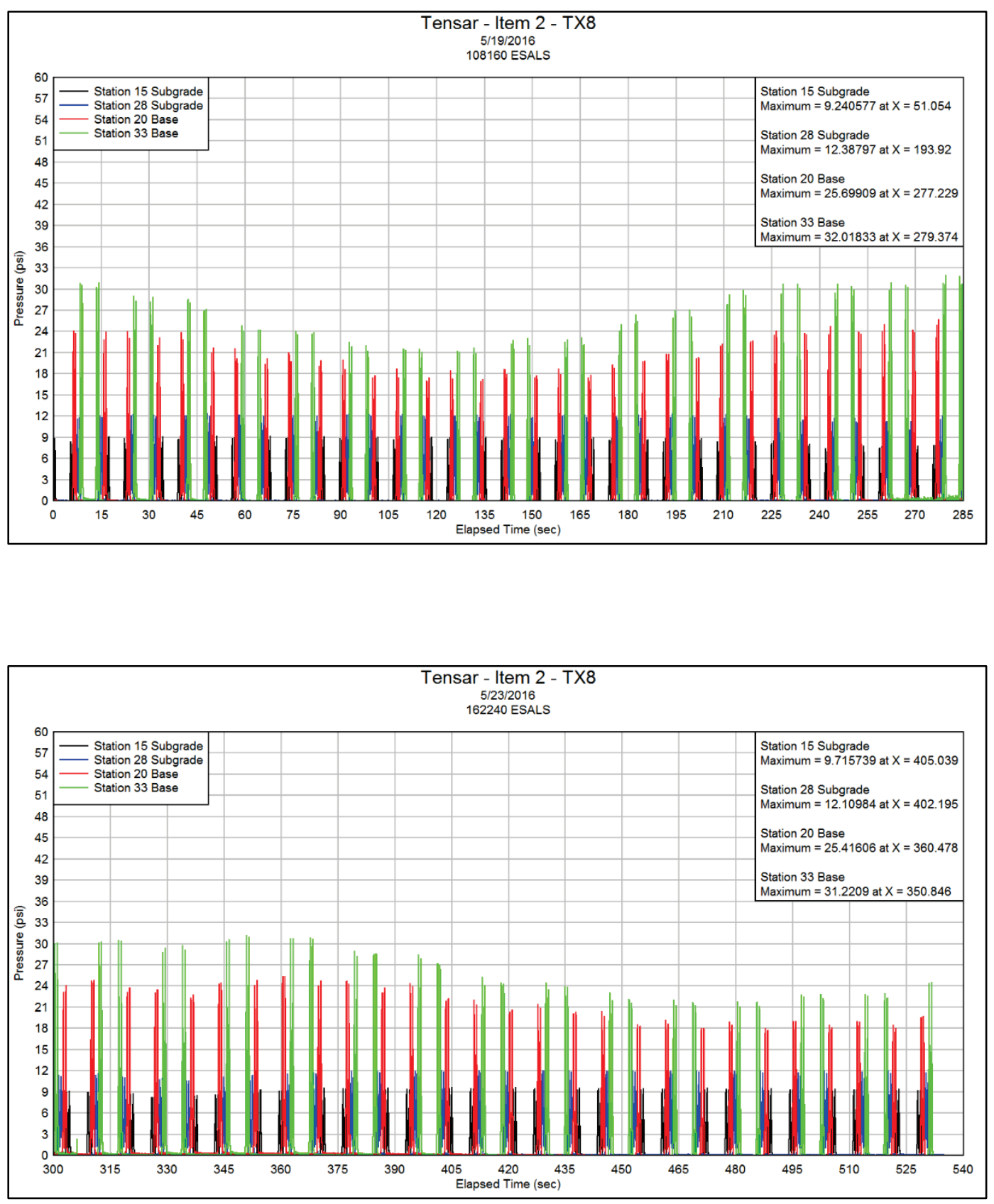

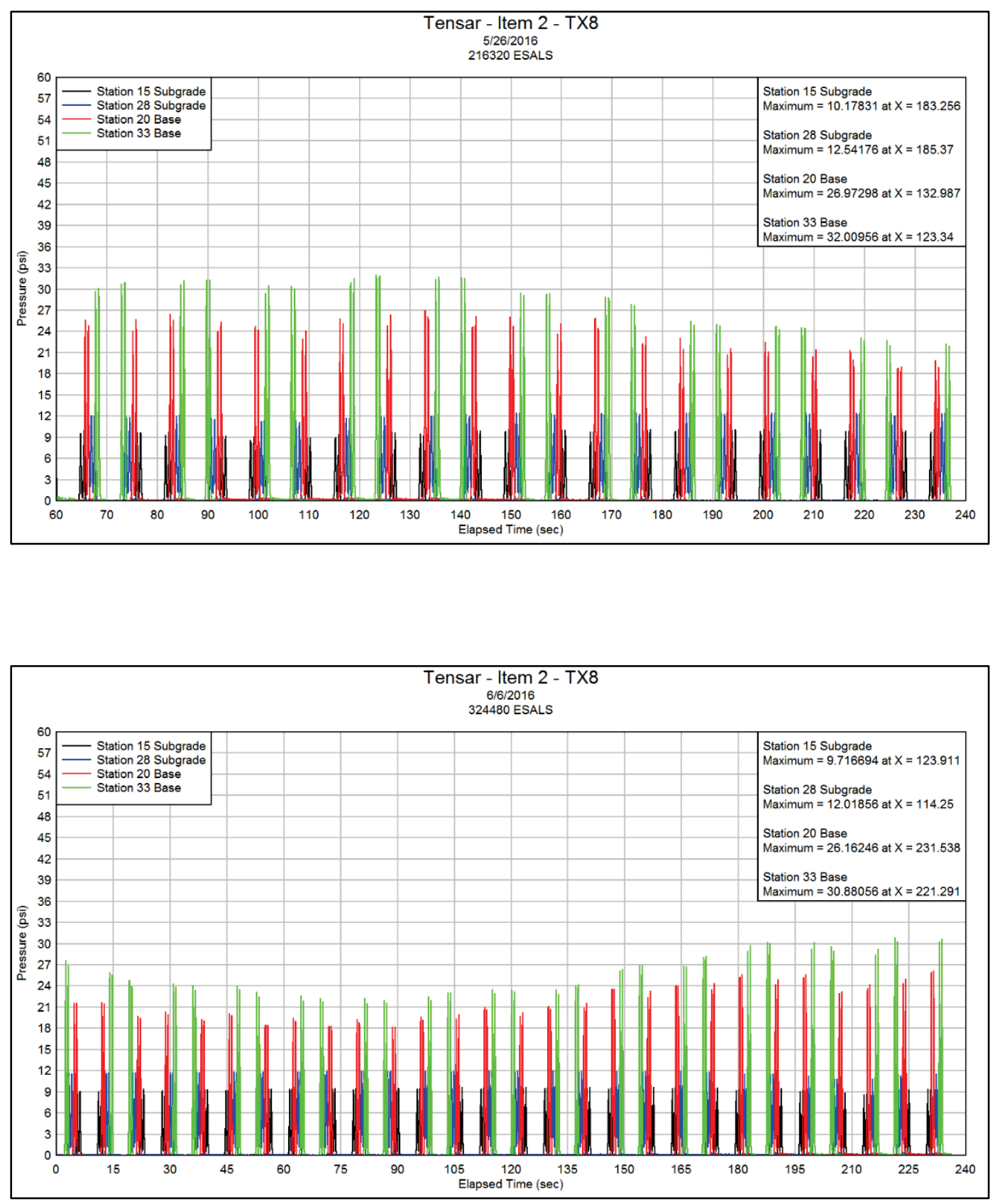

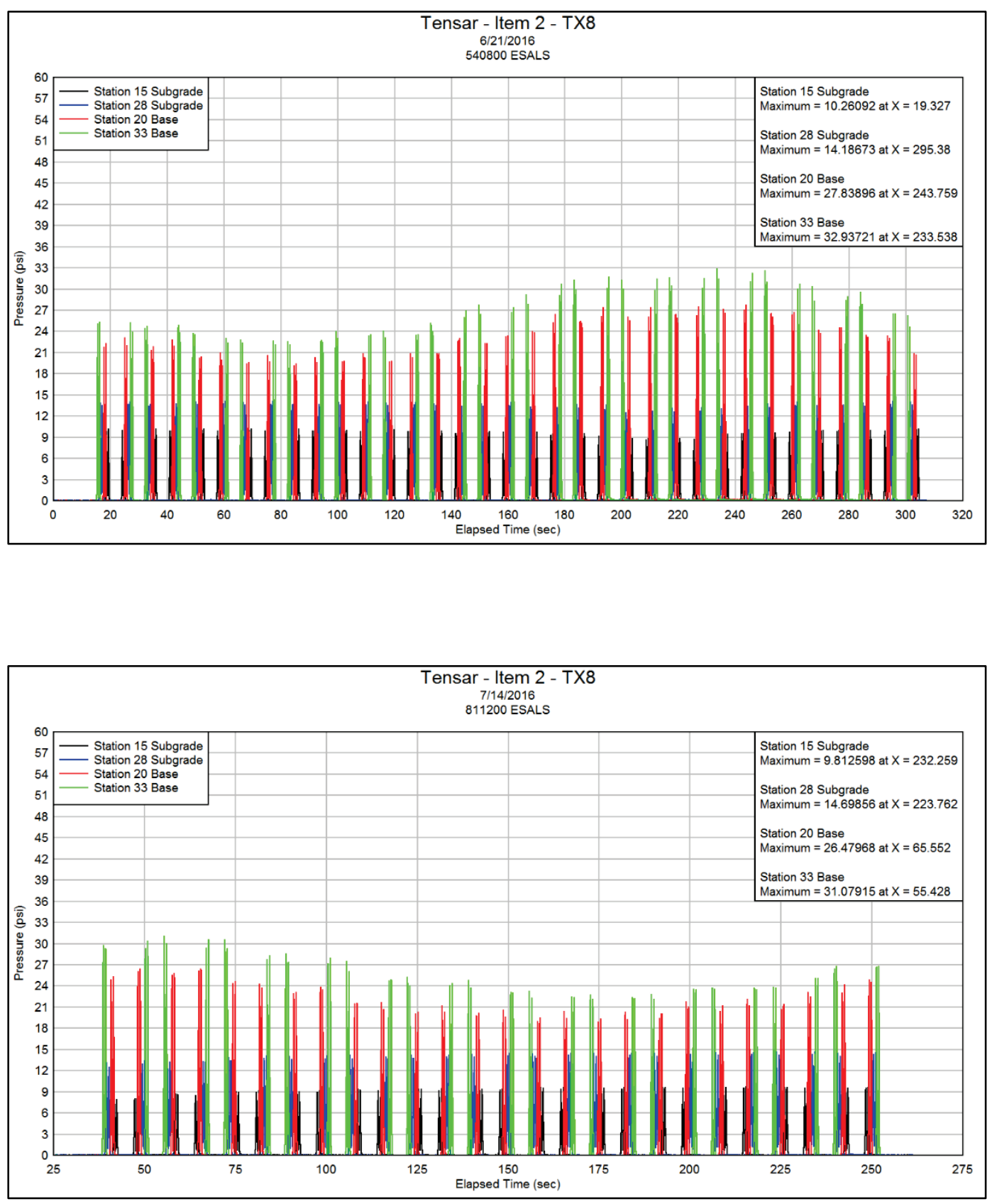


\section{Appendix B: Single-Depth Deflectometer Responses}
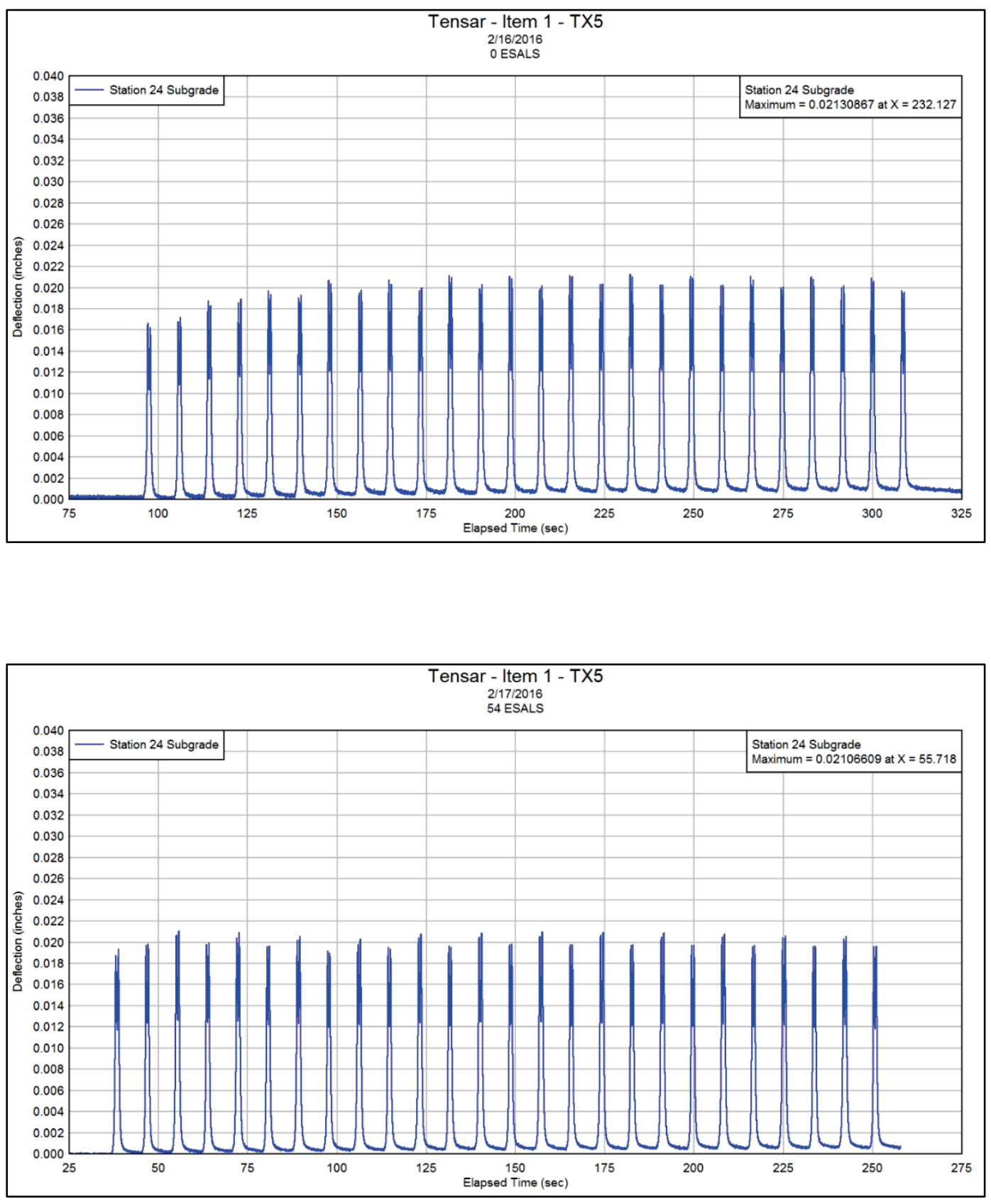

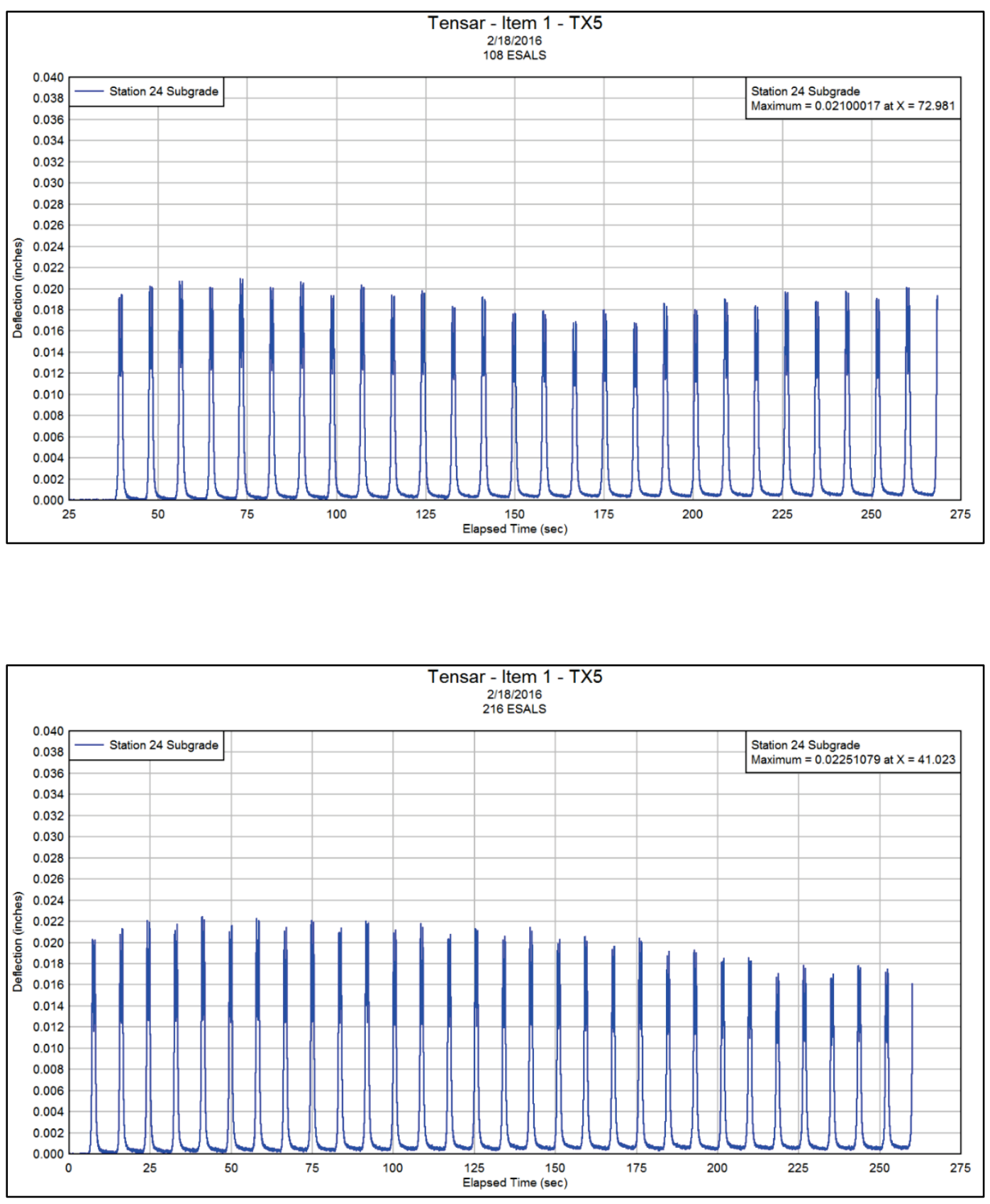

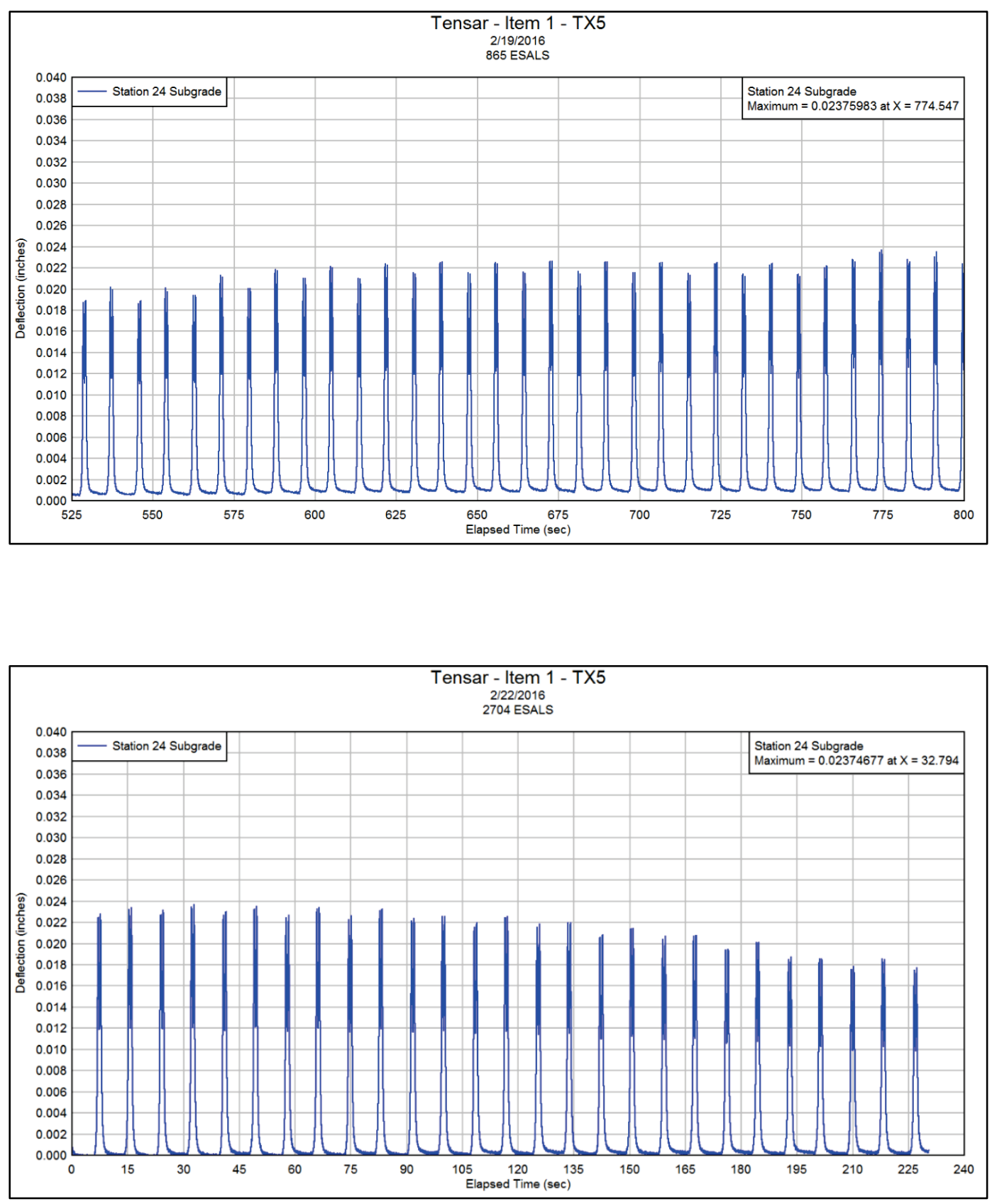

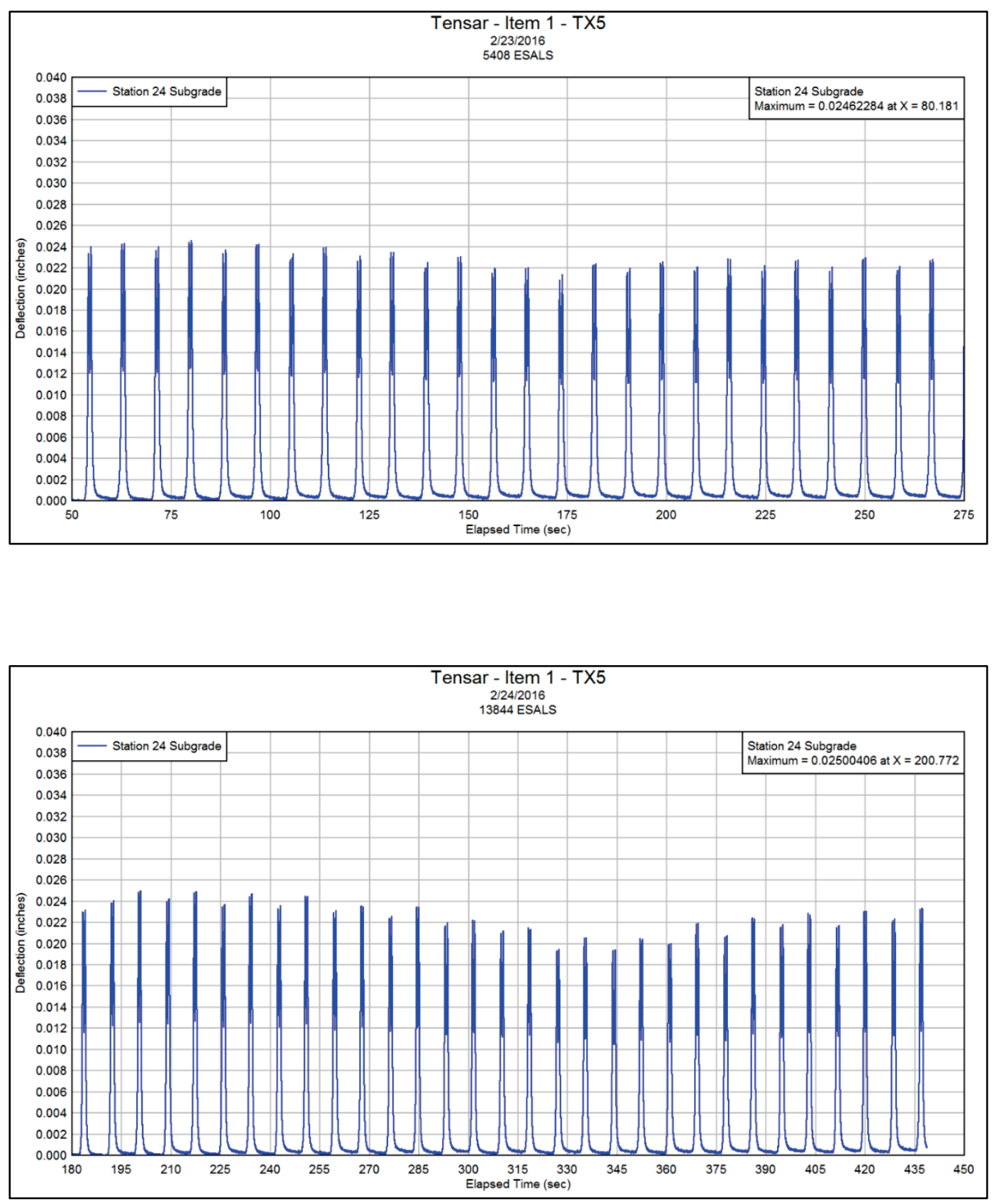

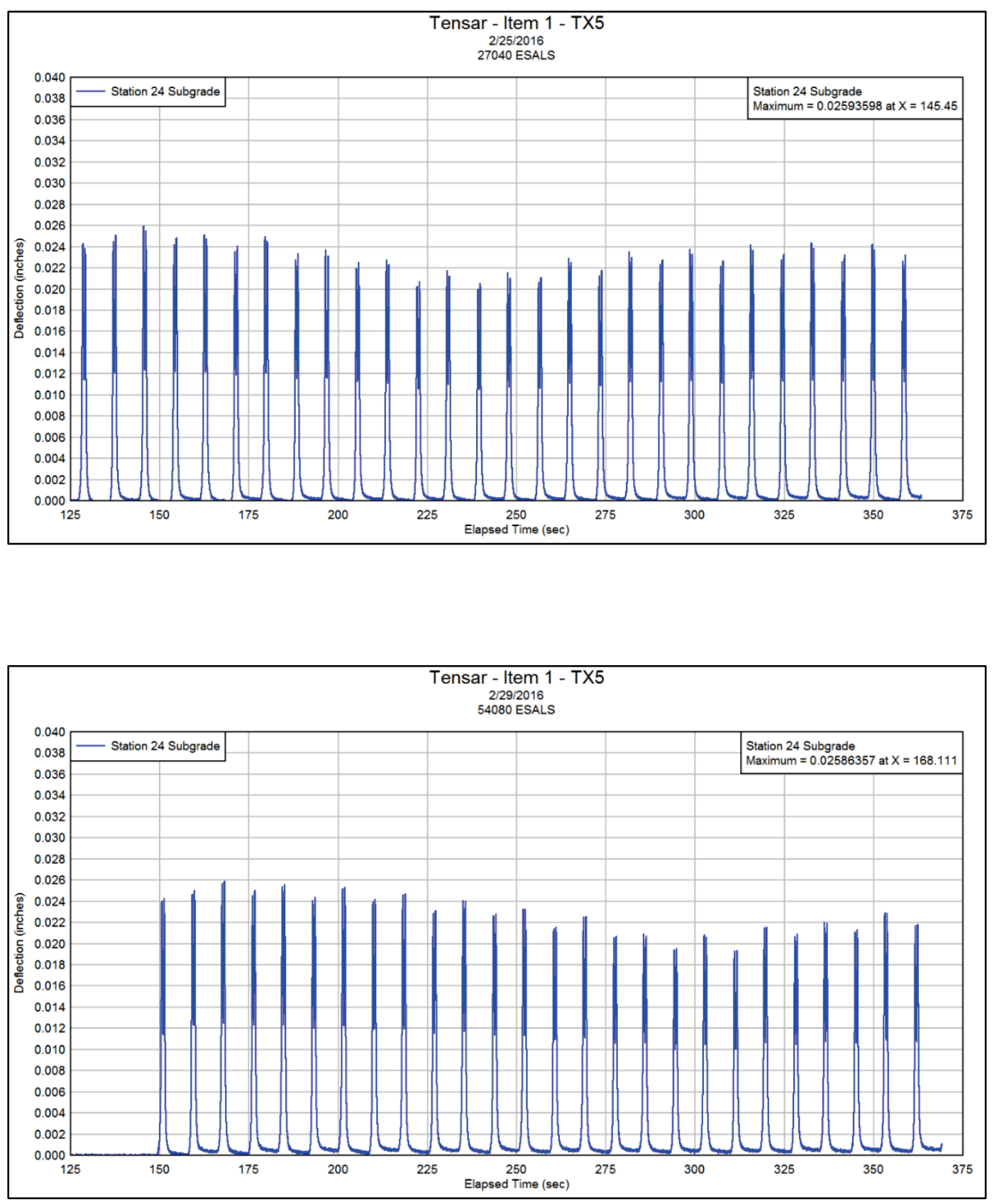

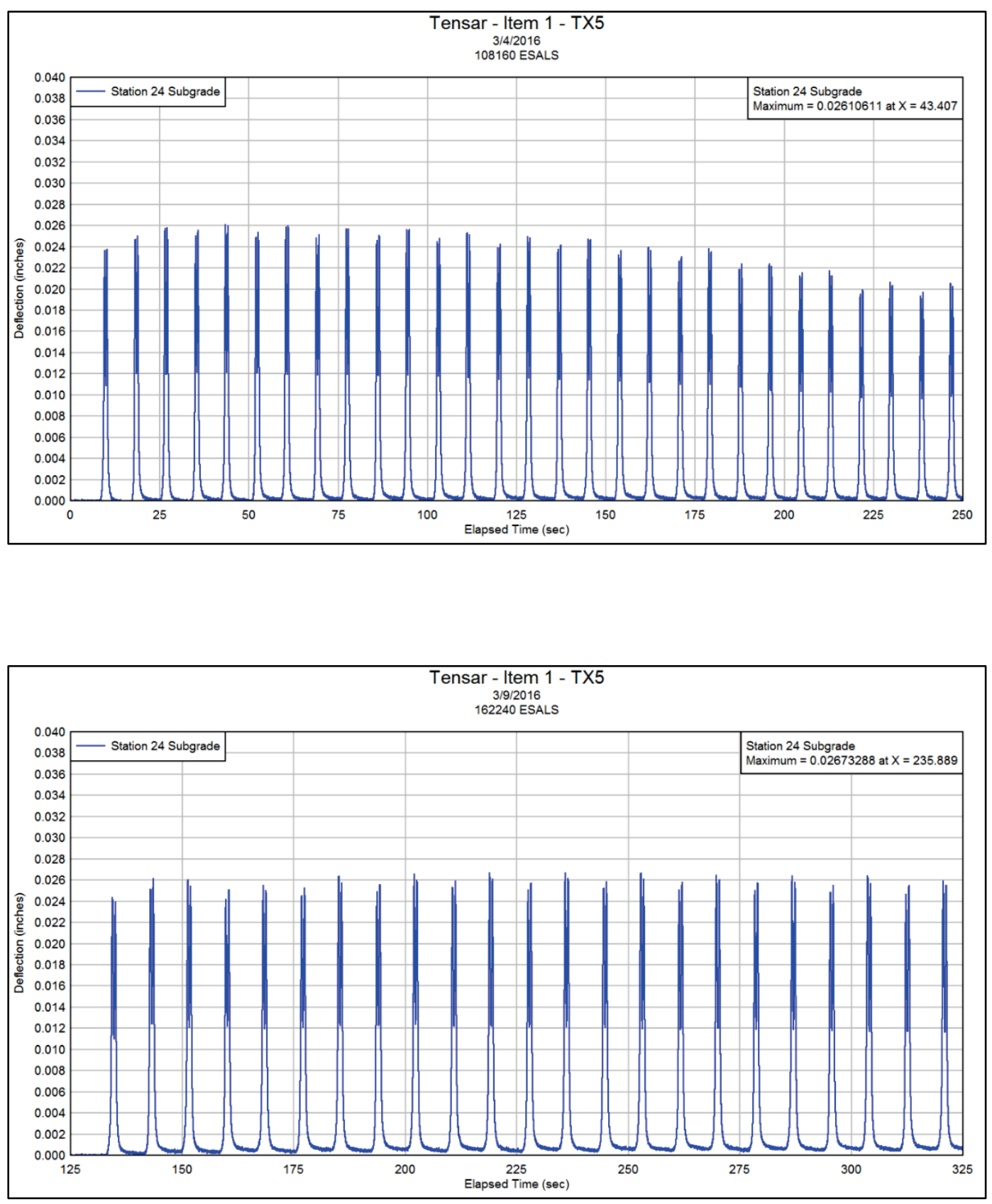

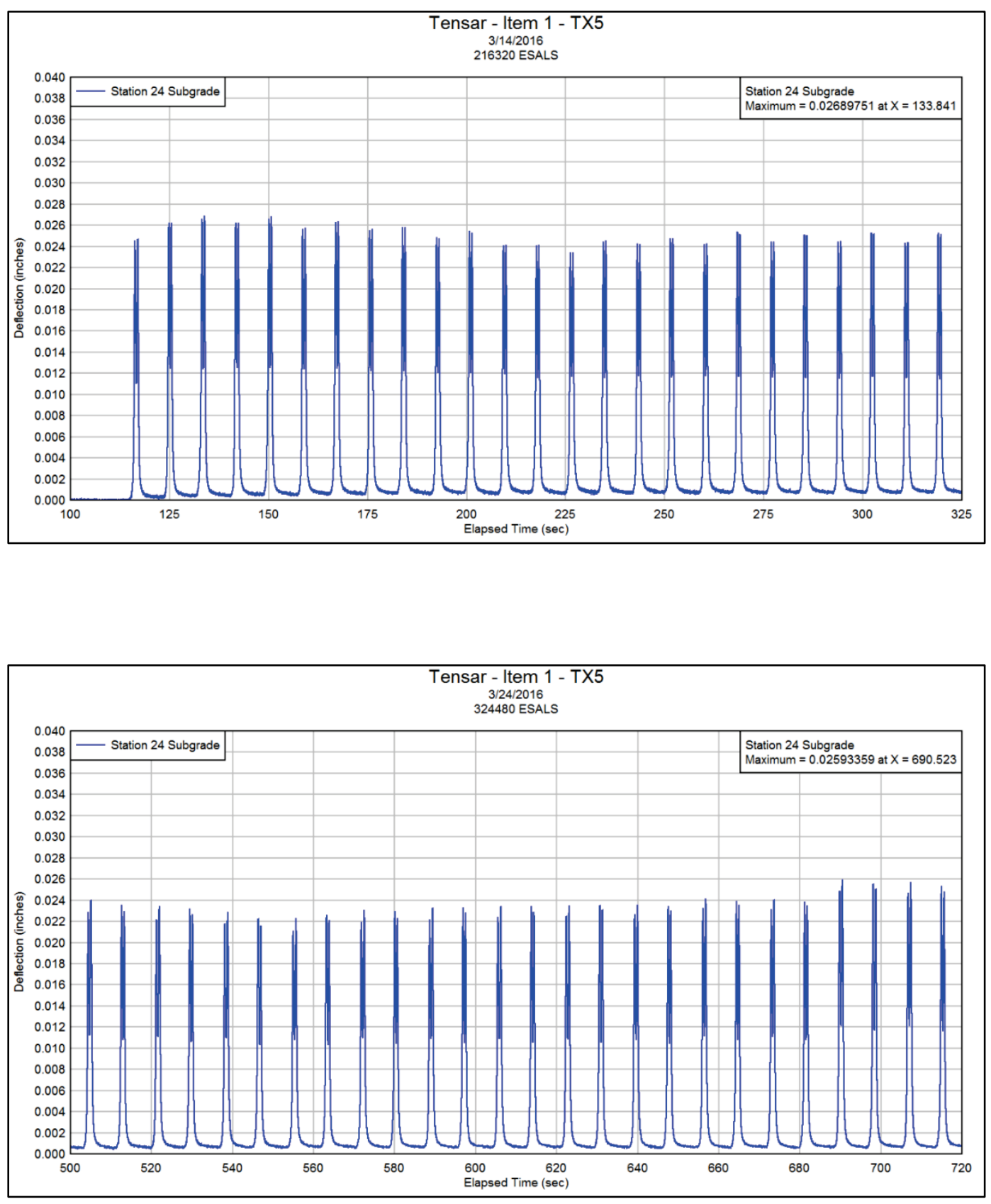

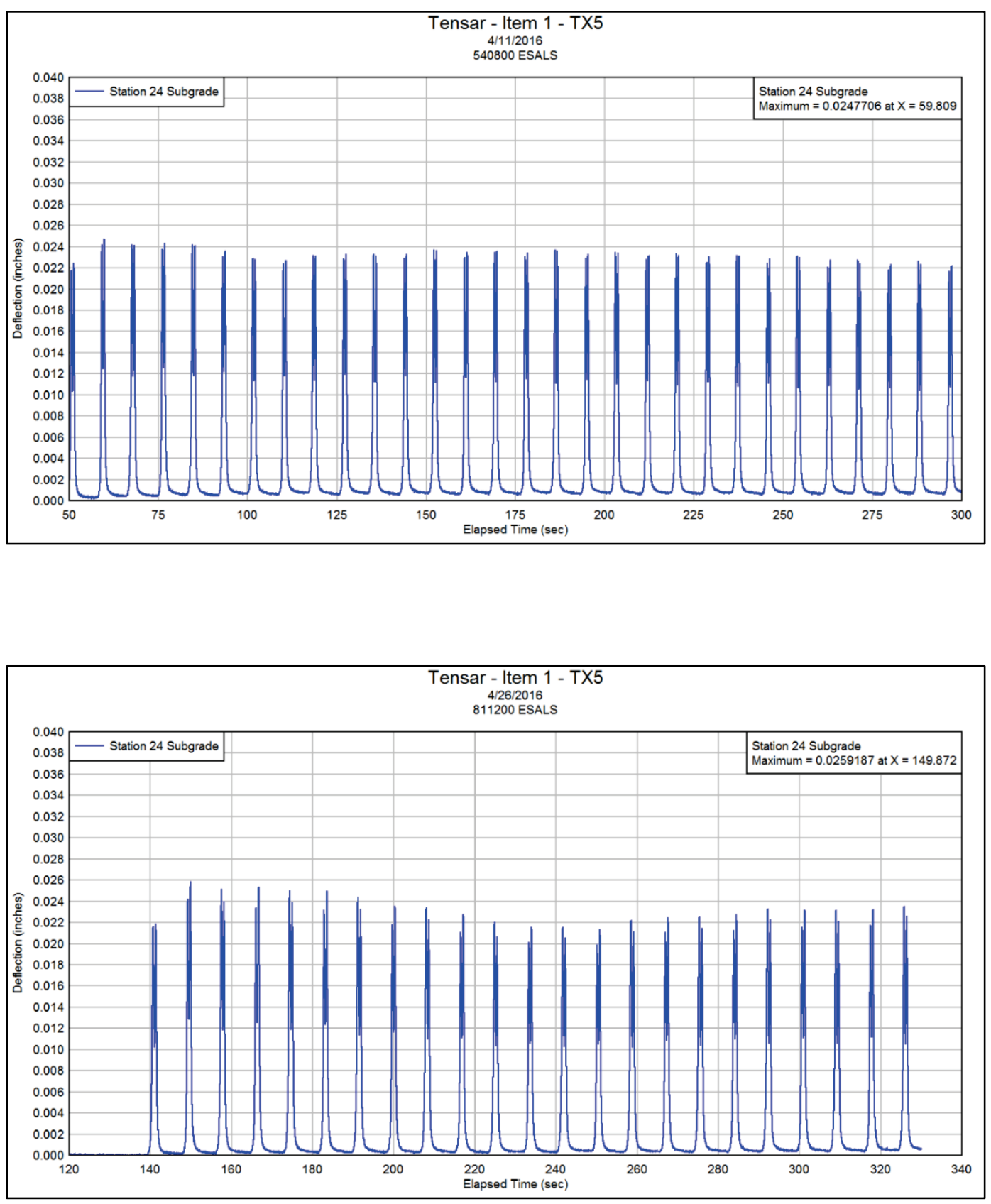

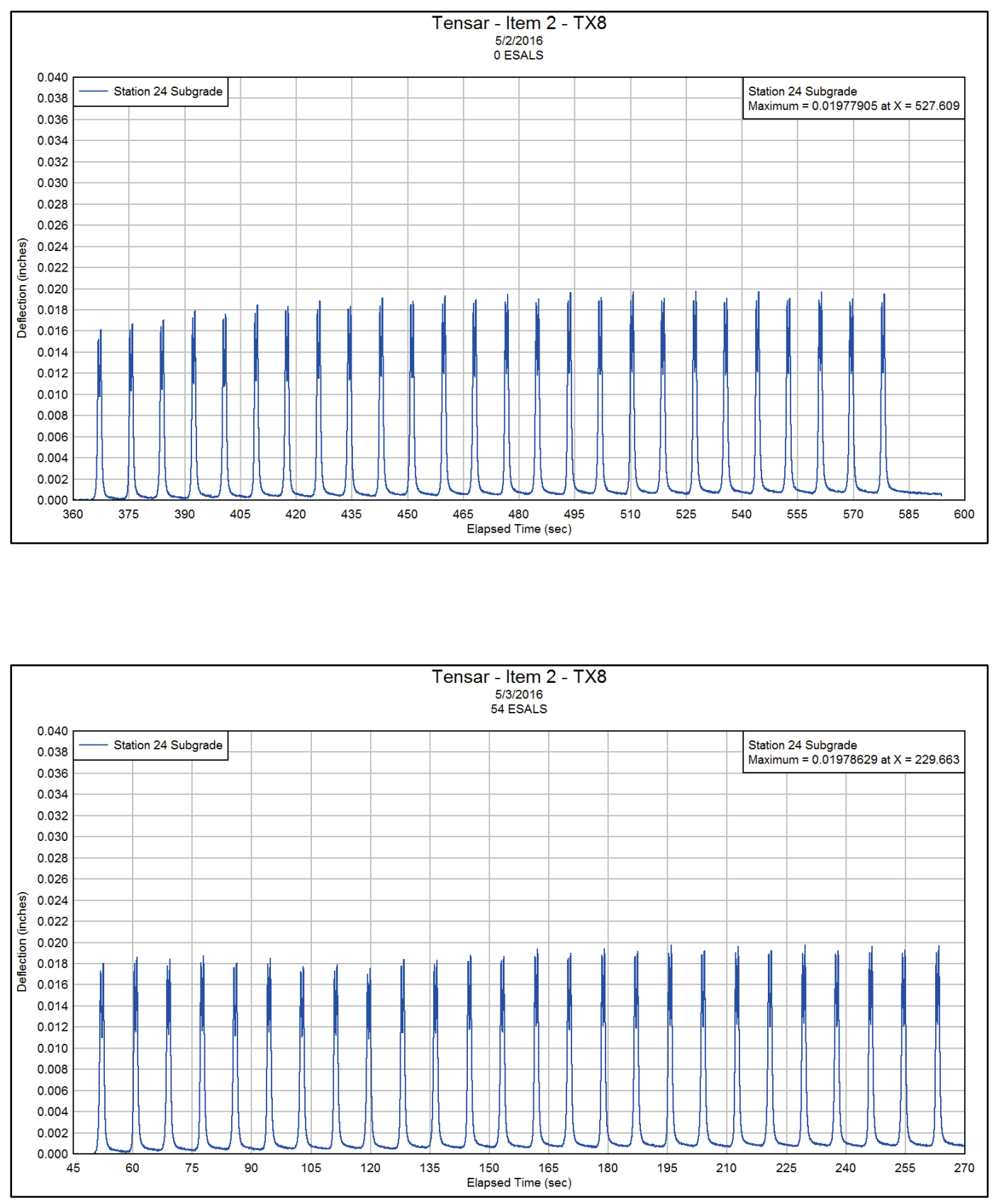

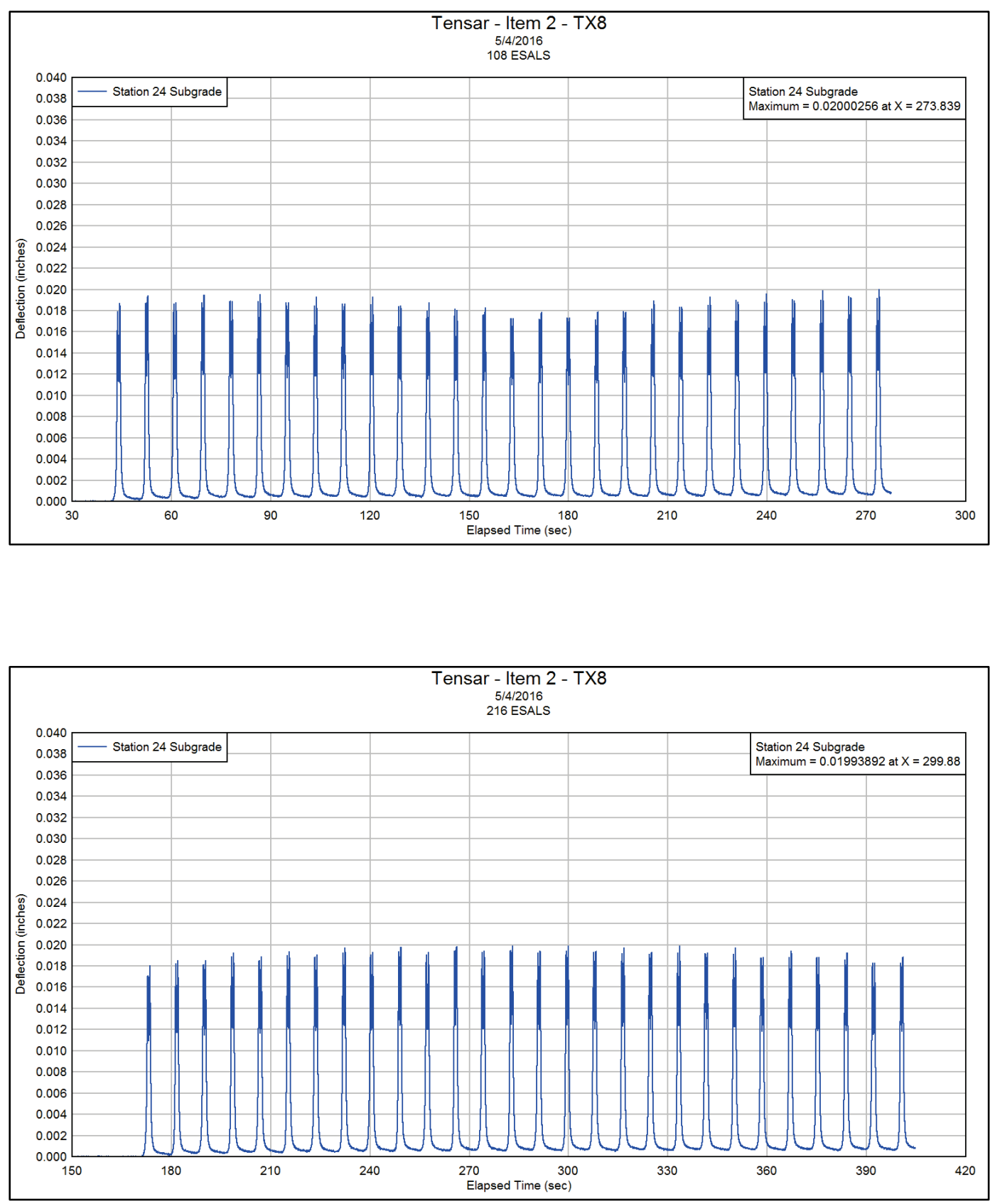

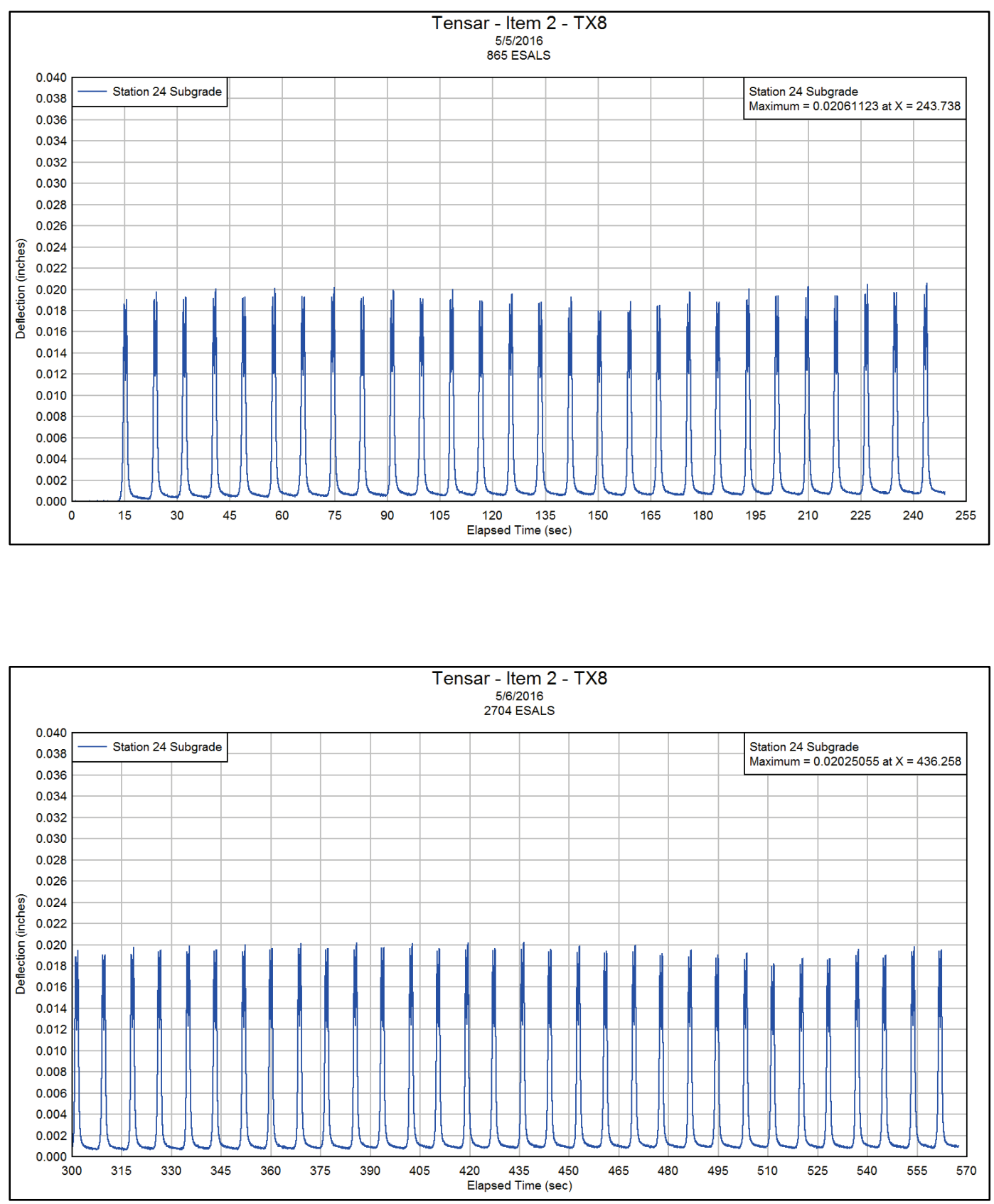

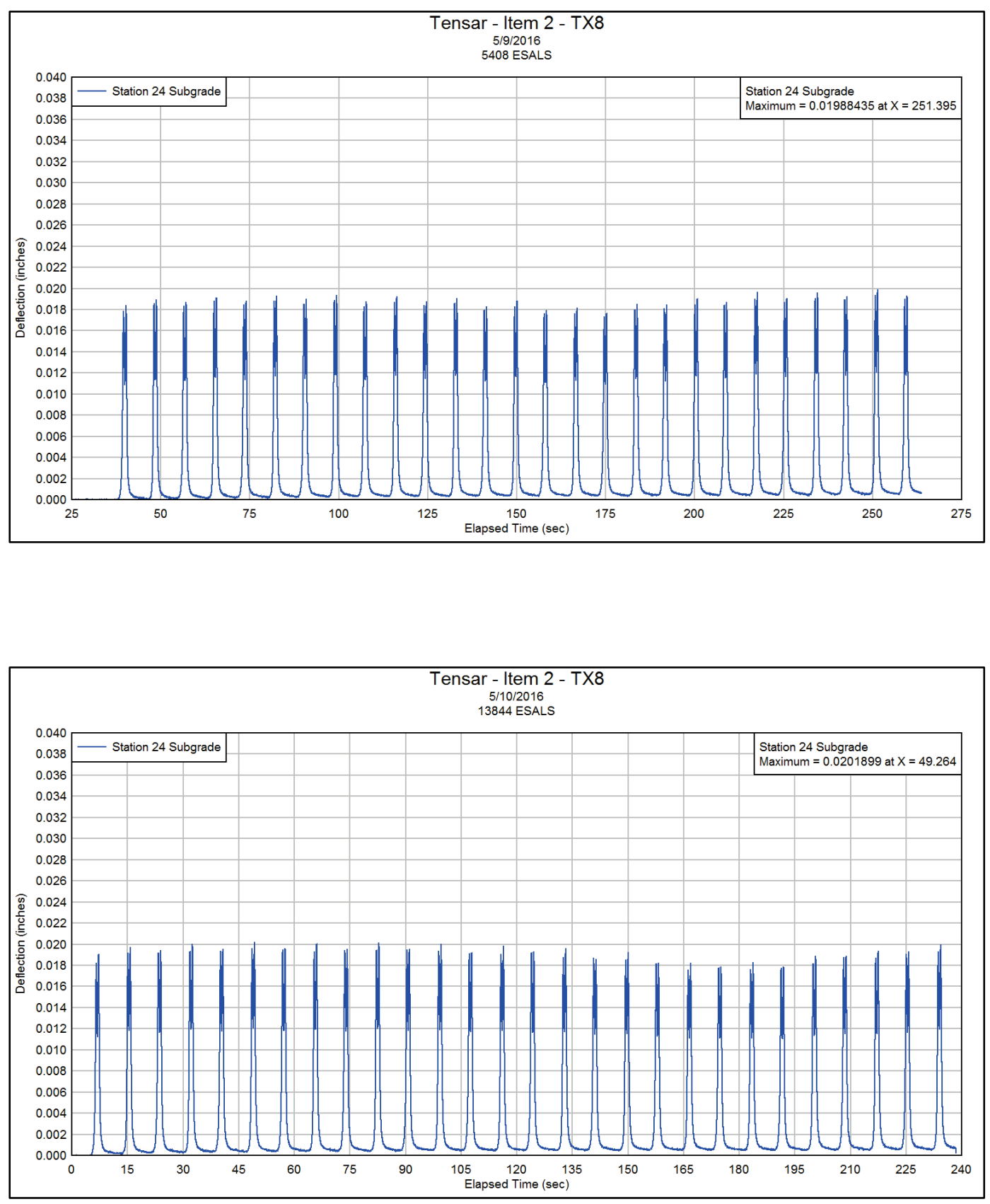

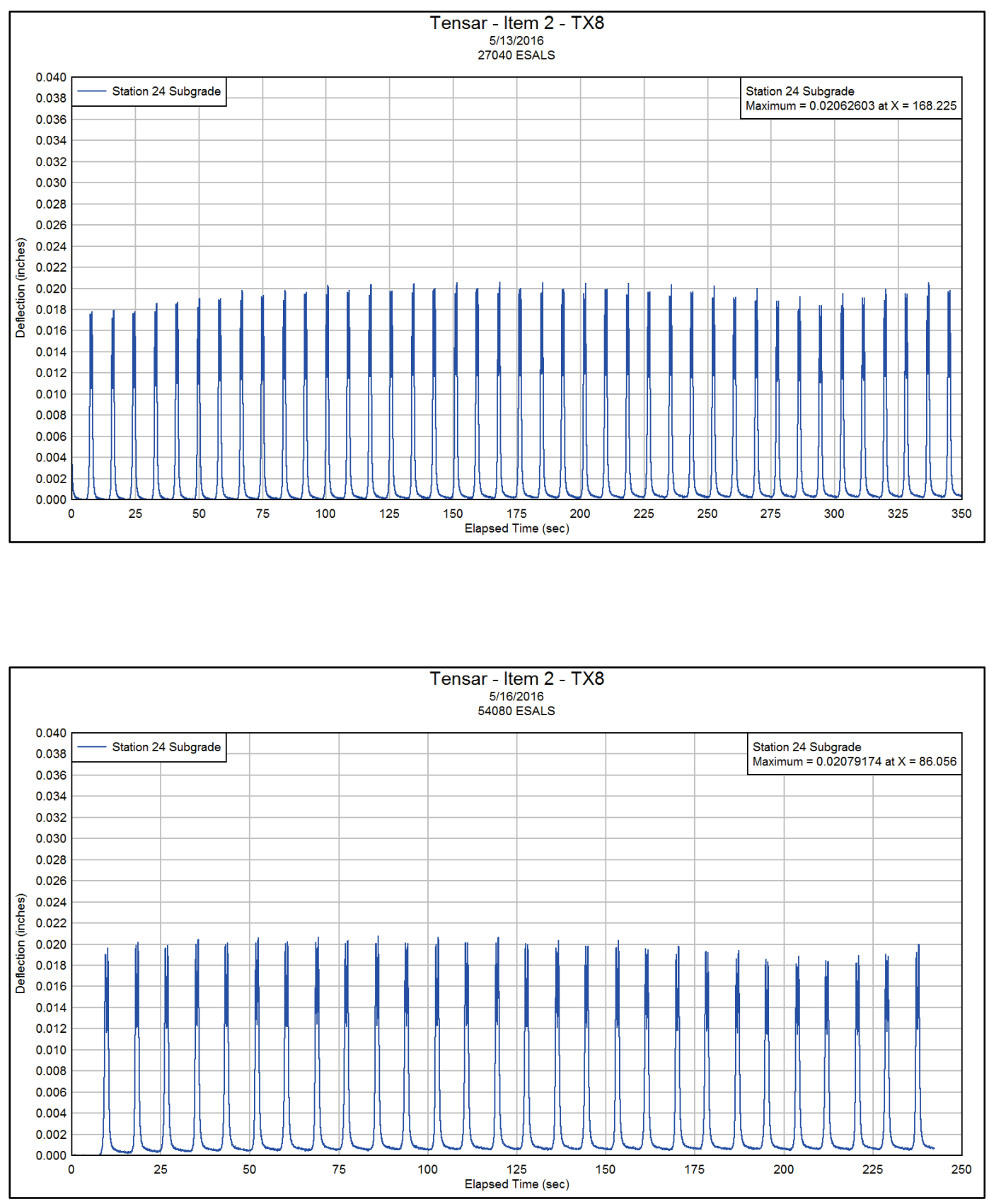

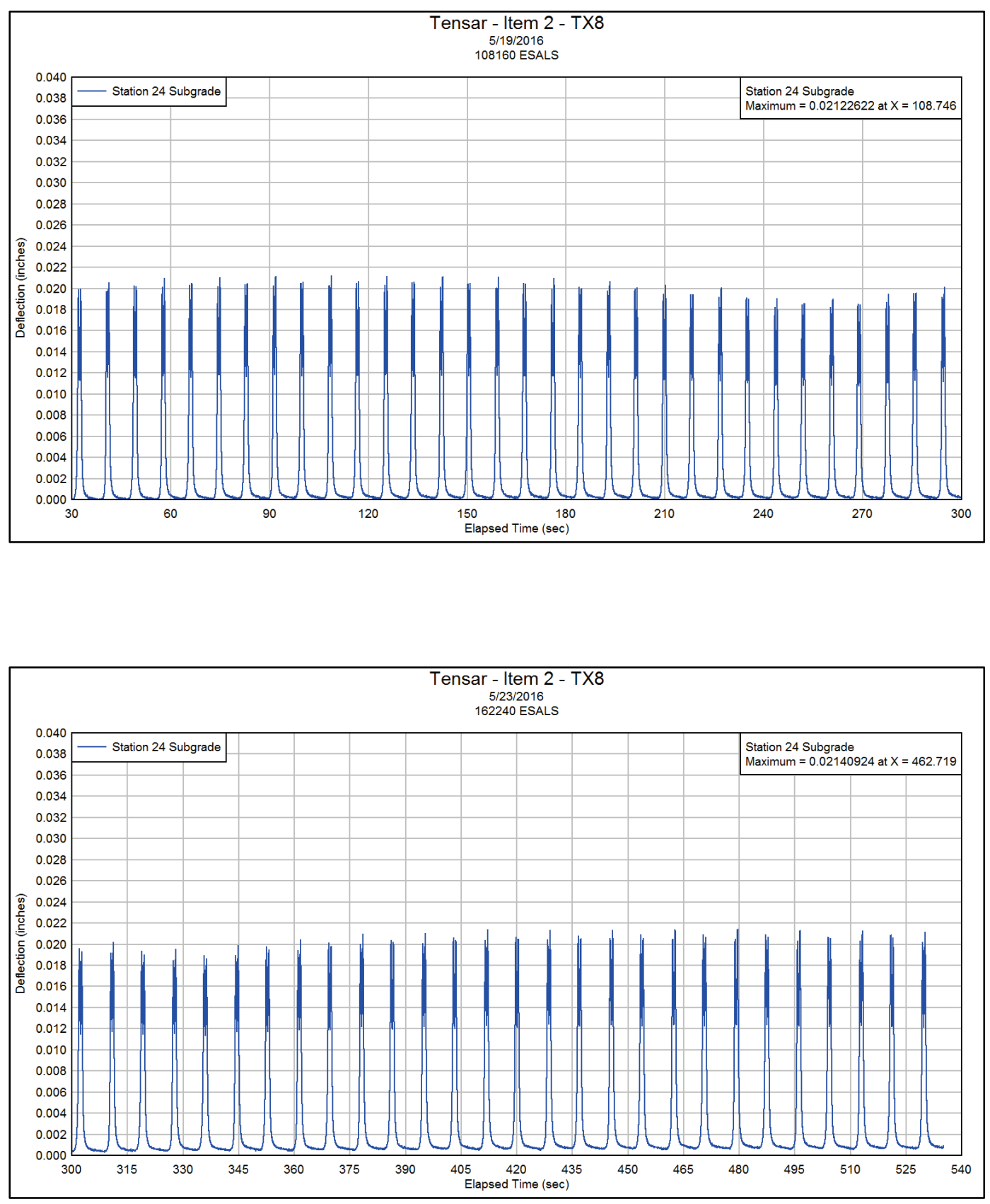

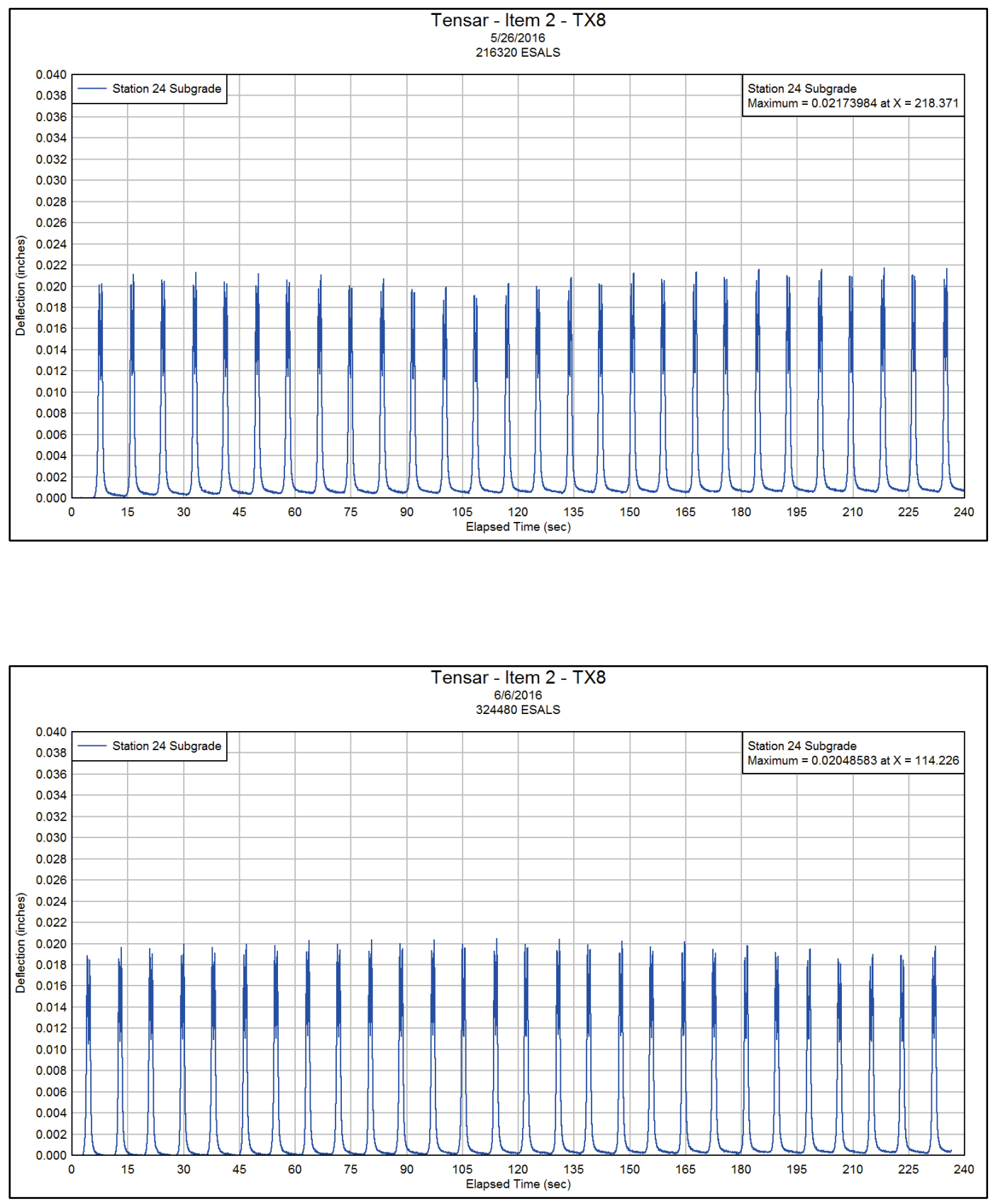

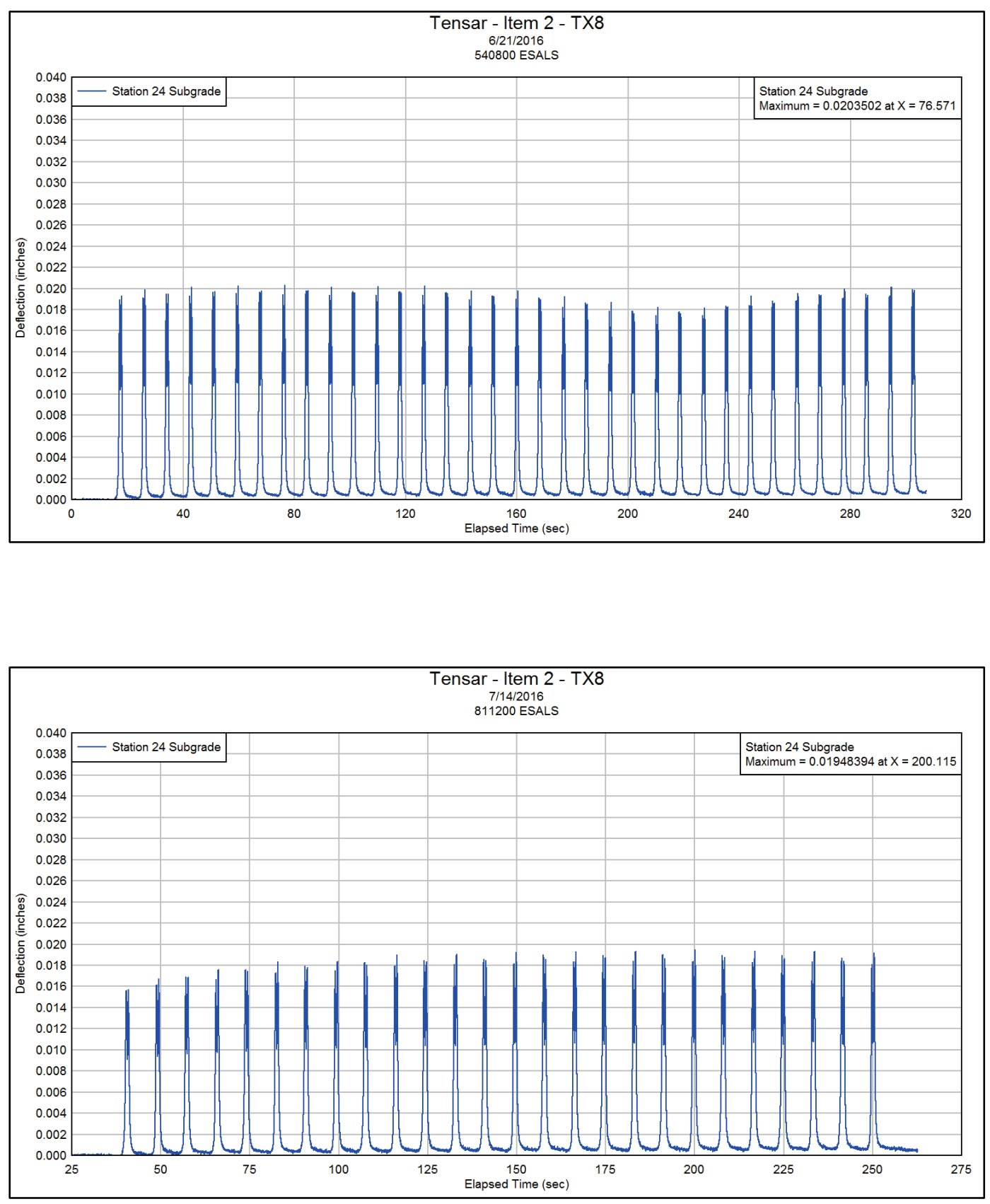


\section{Appendix C: Asphalt Strain Gauge Responses}
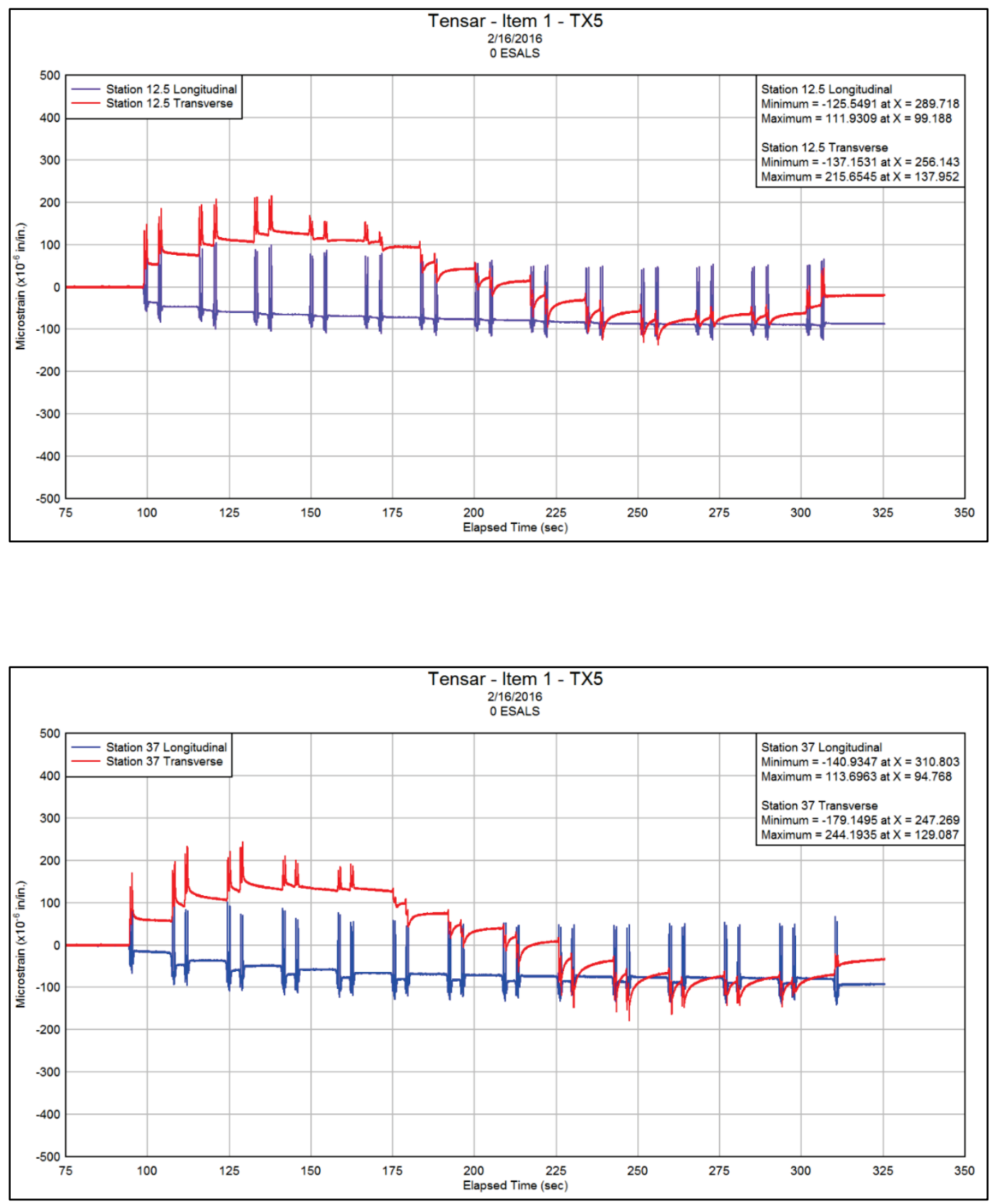

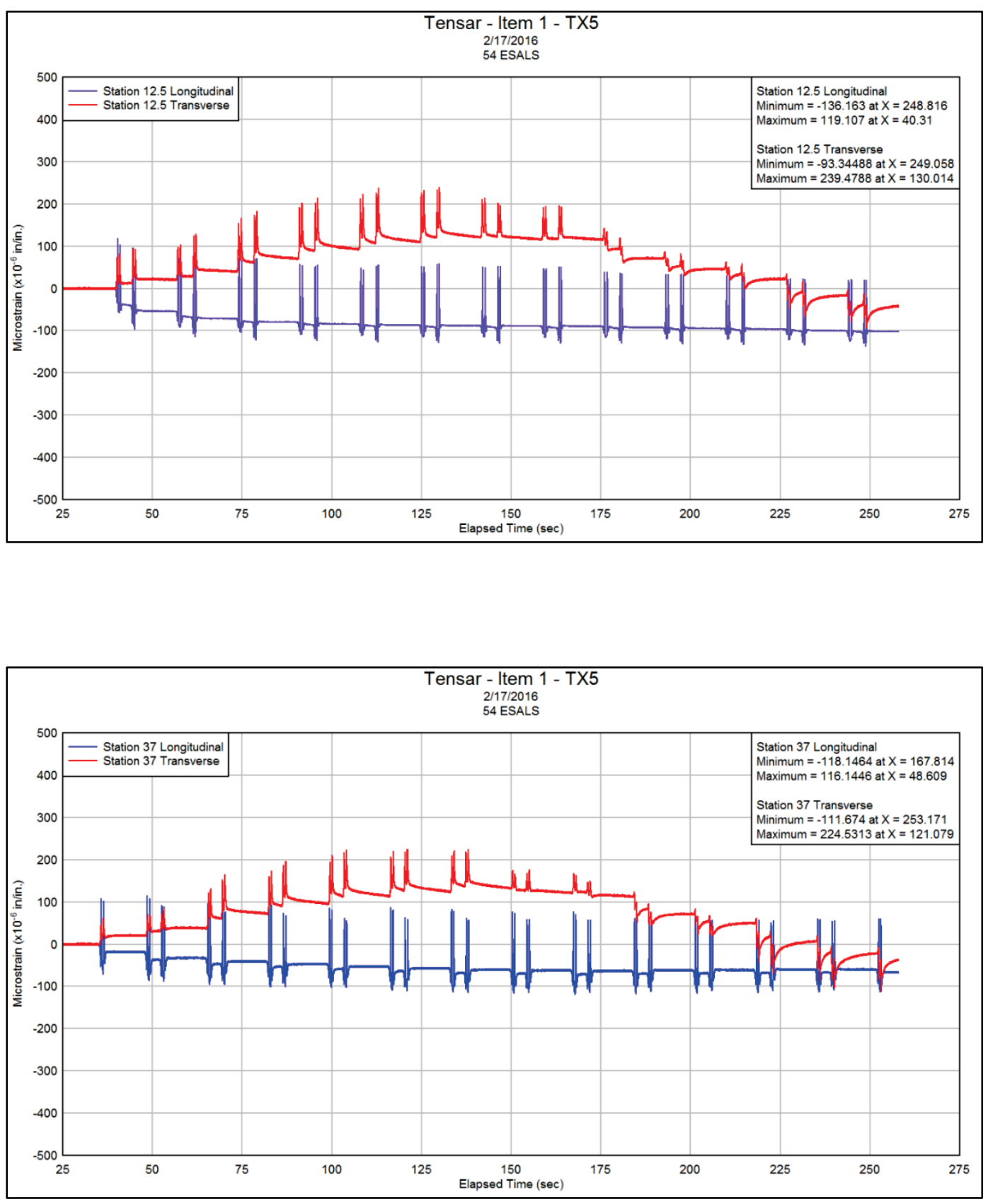

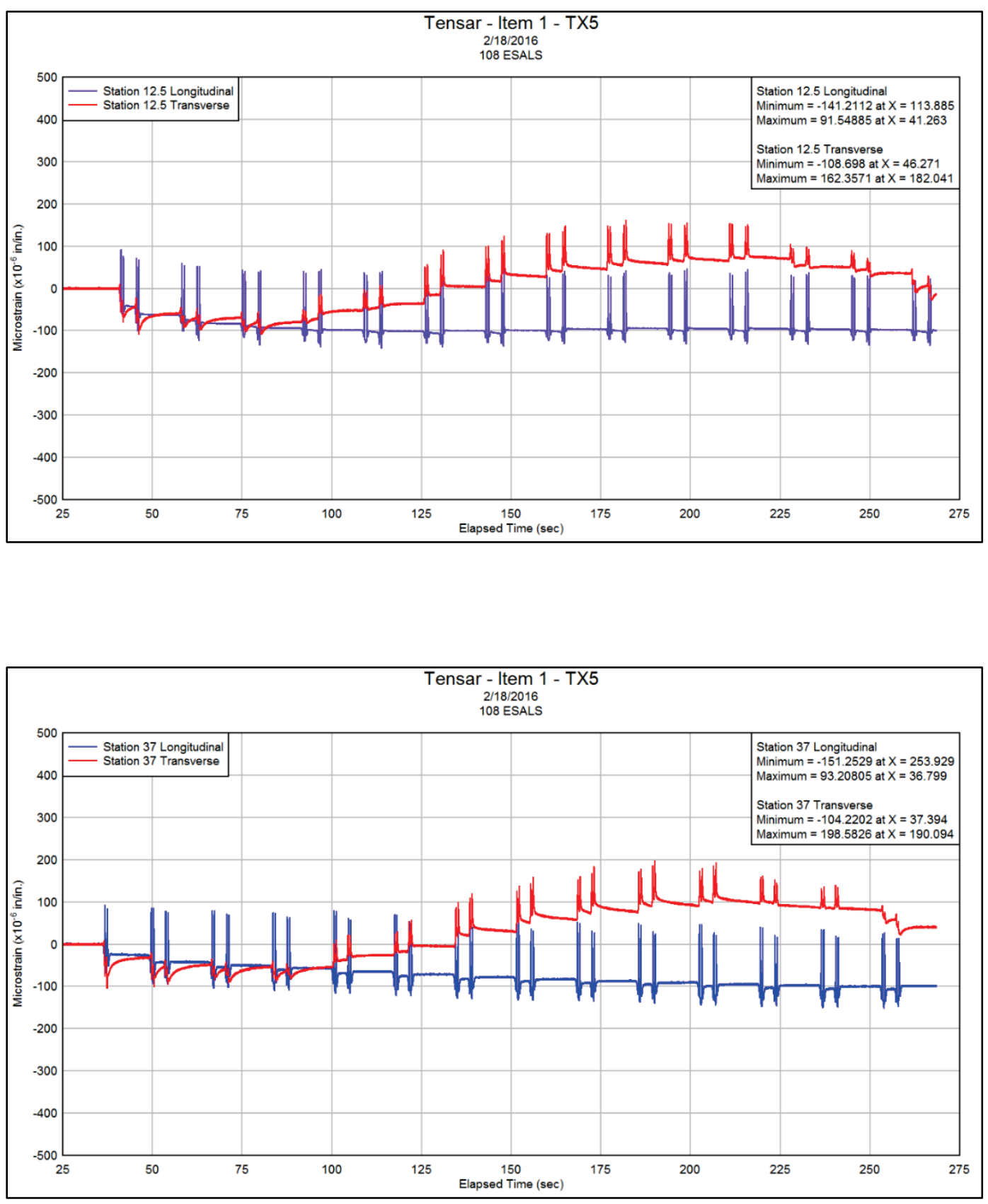

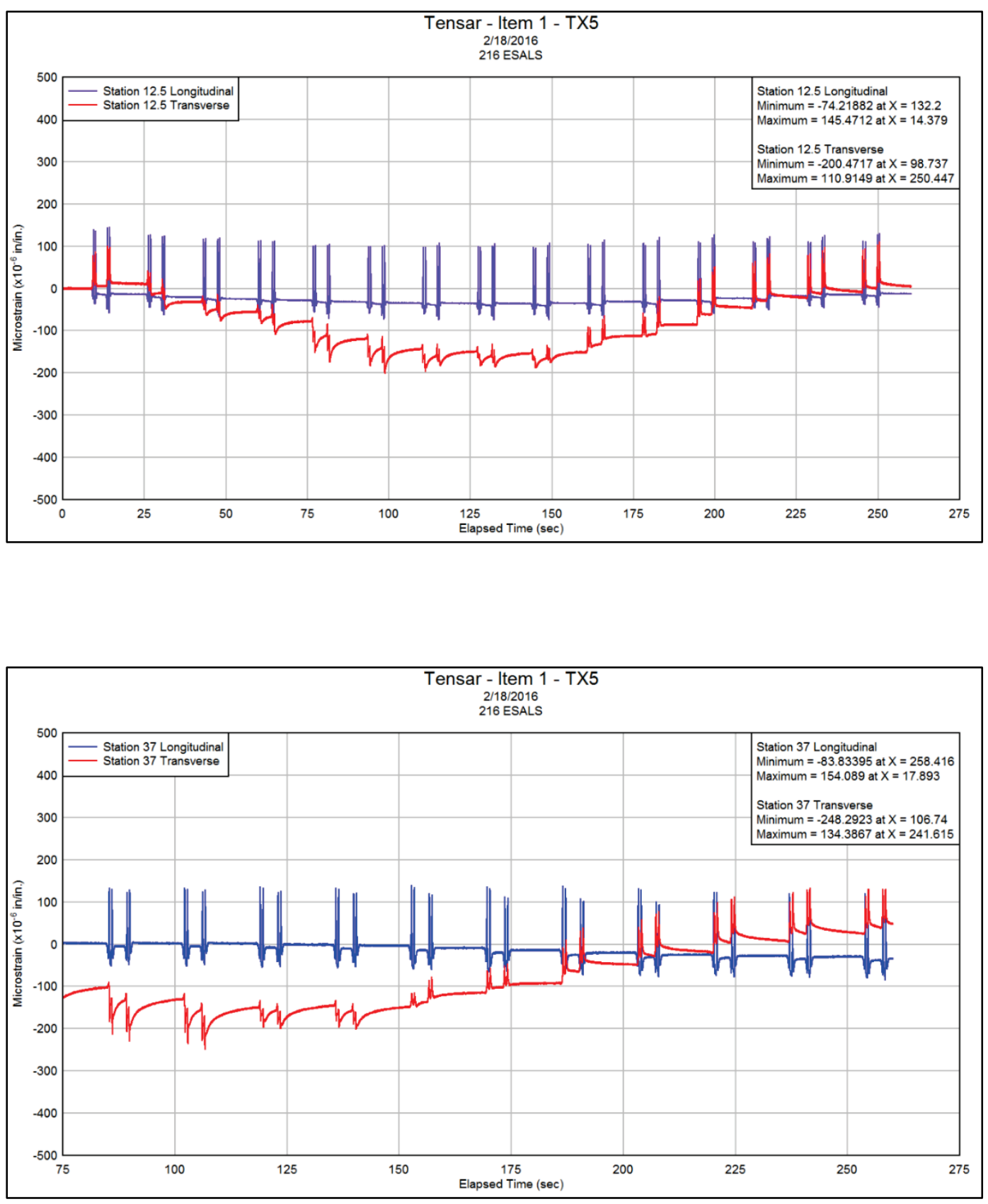

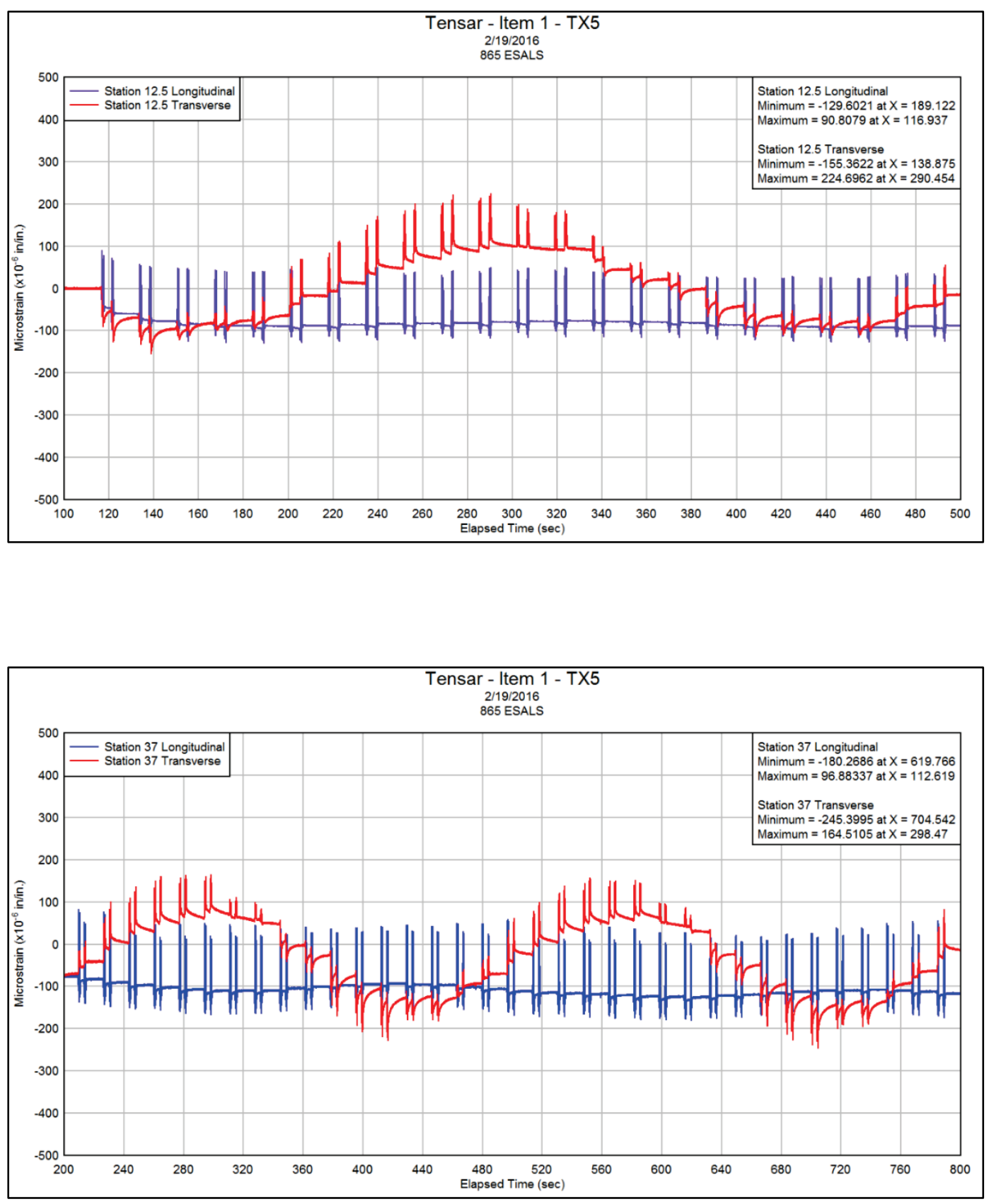

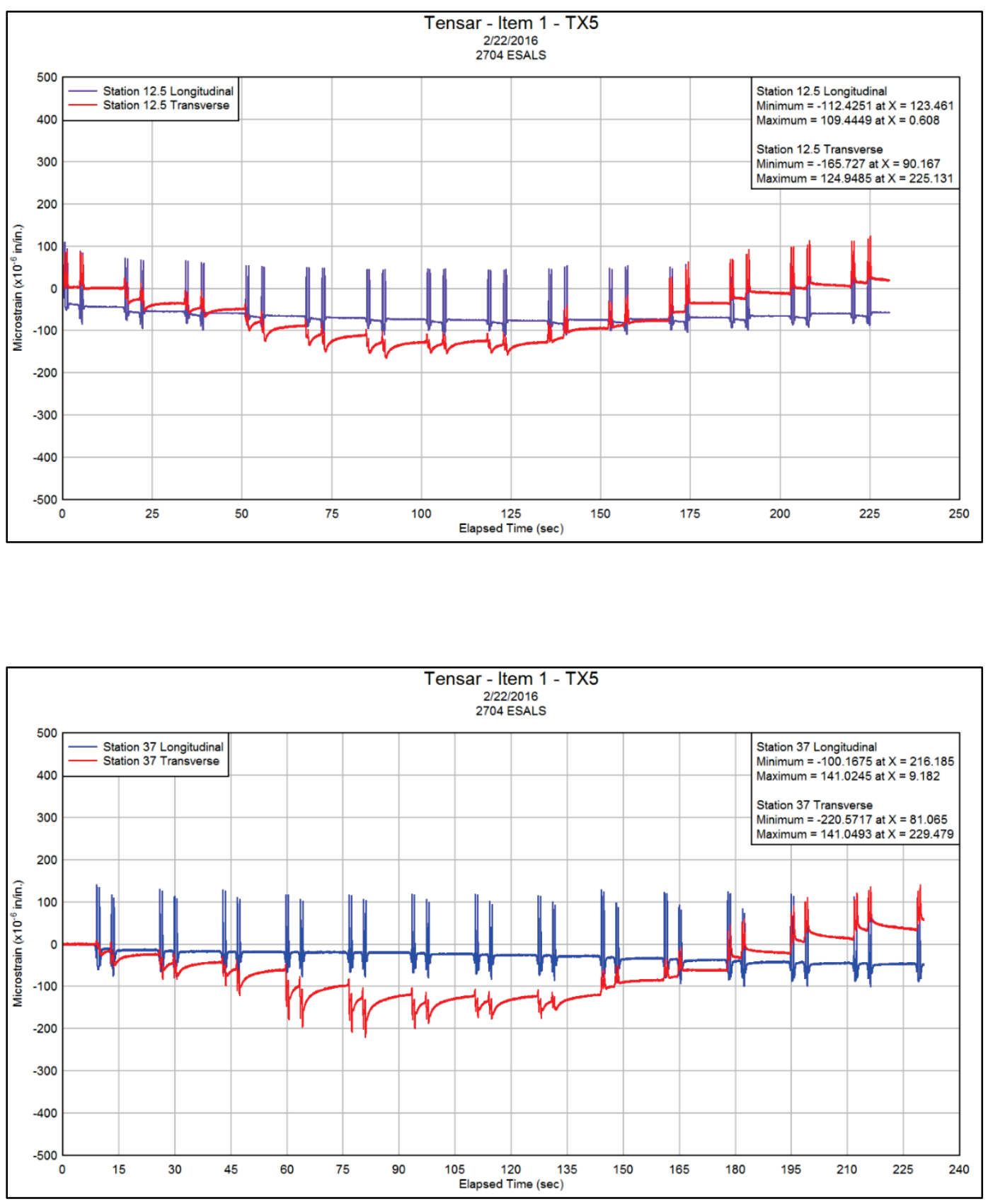

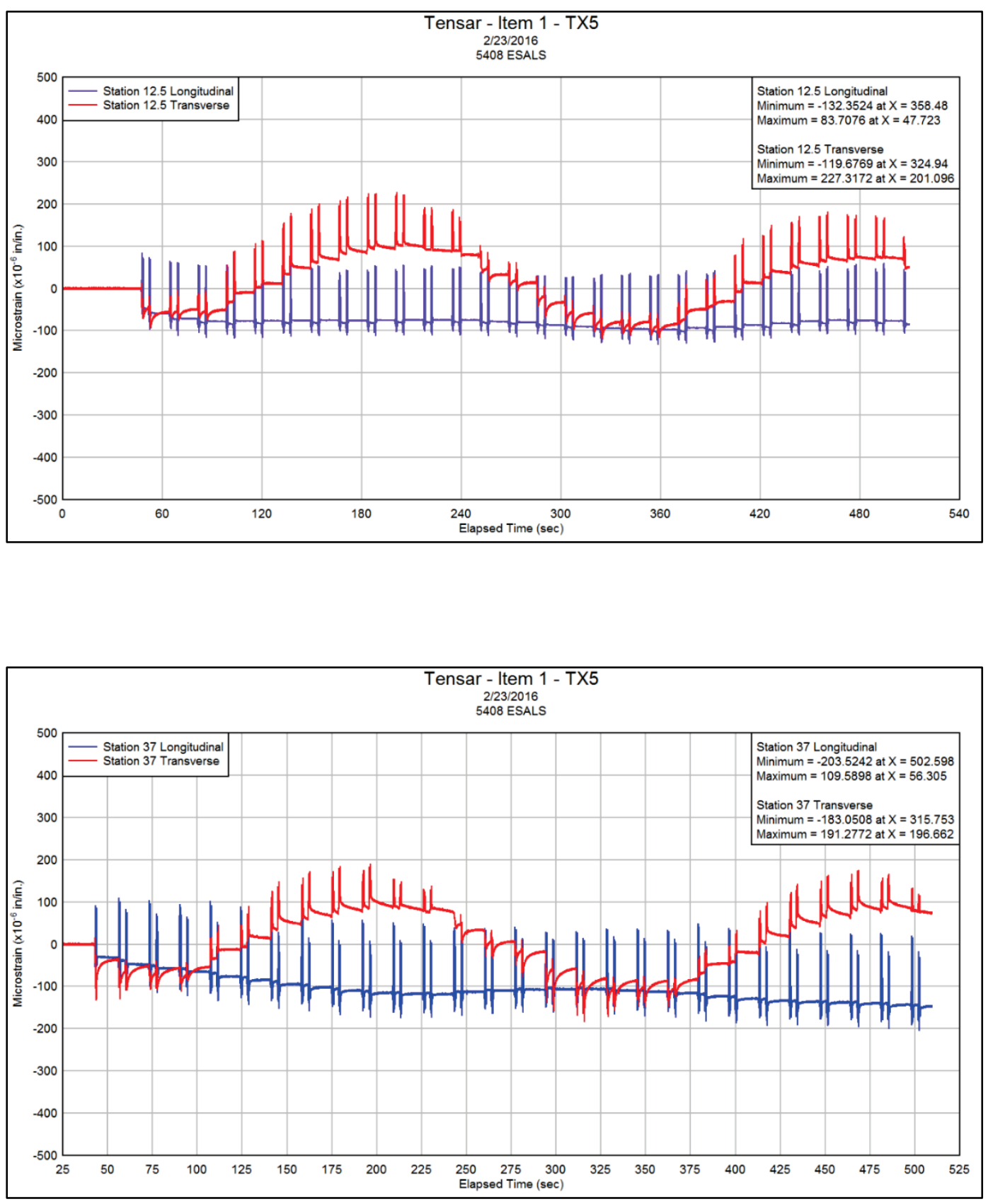

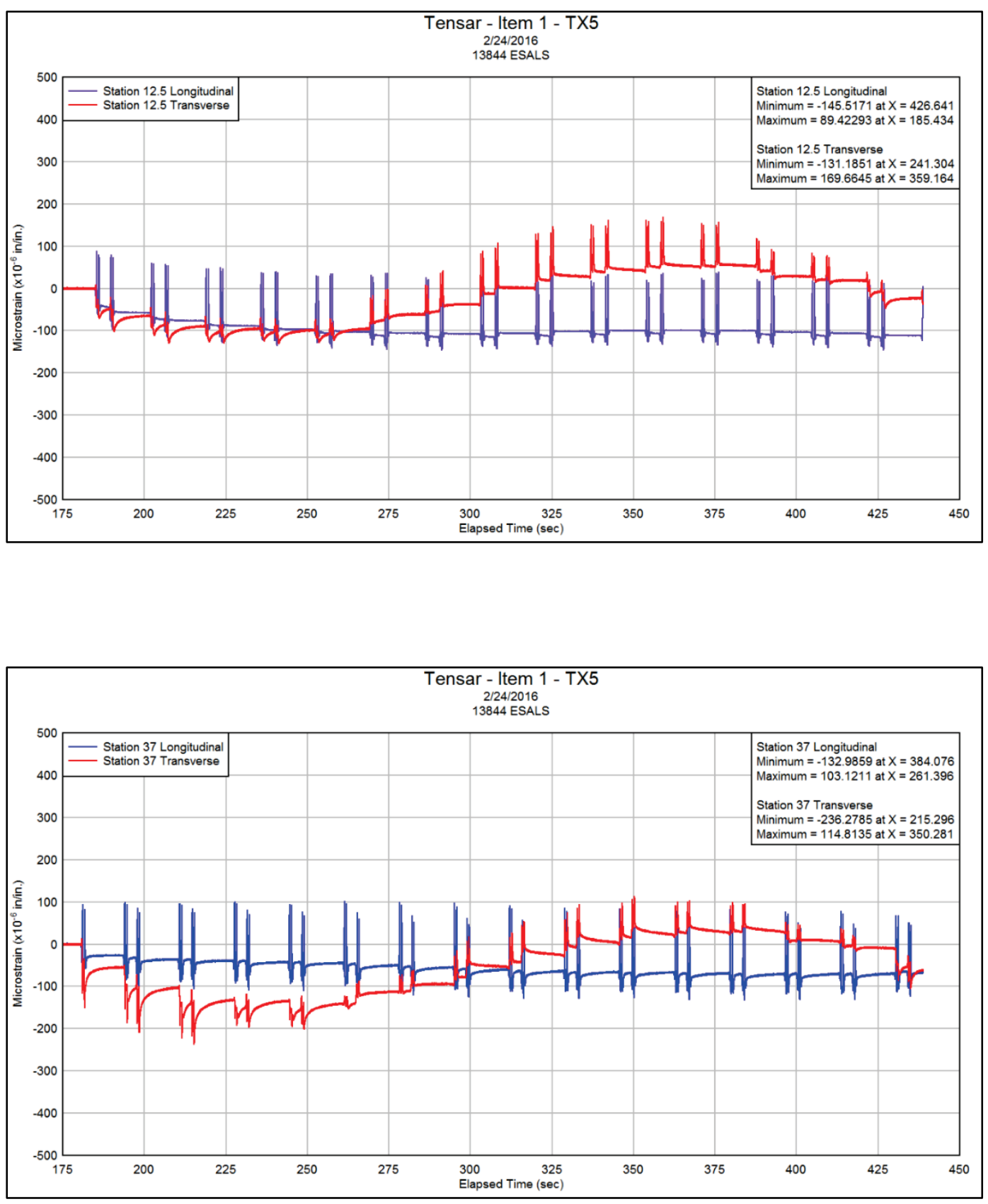

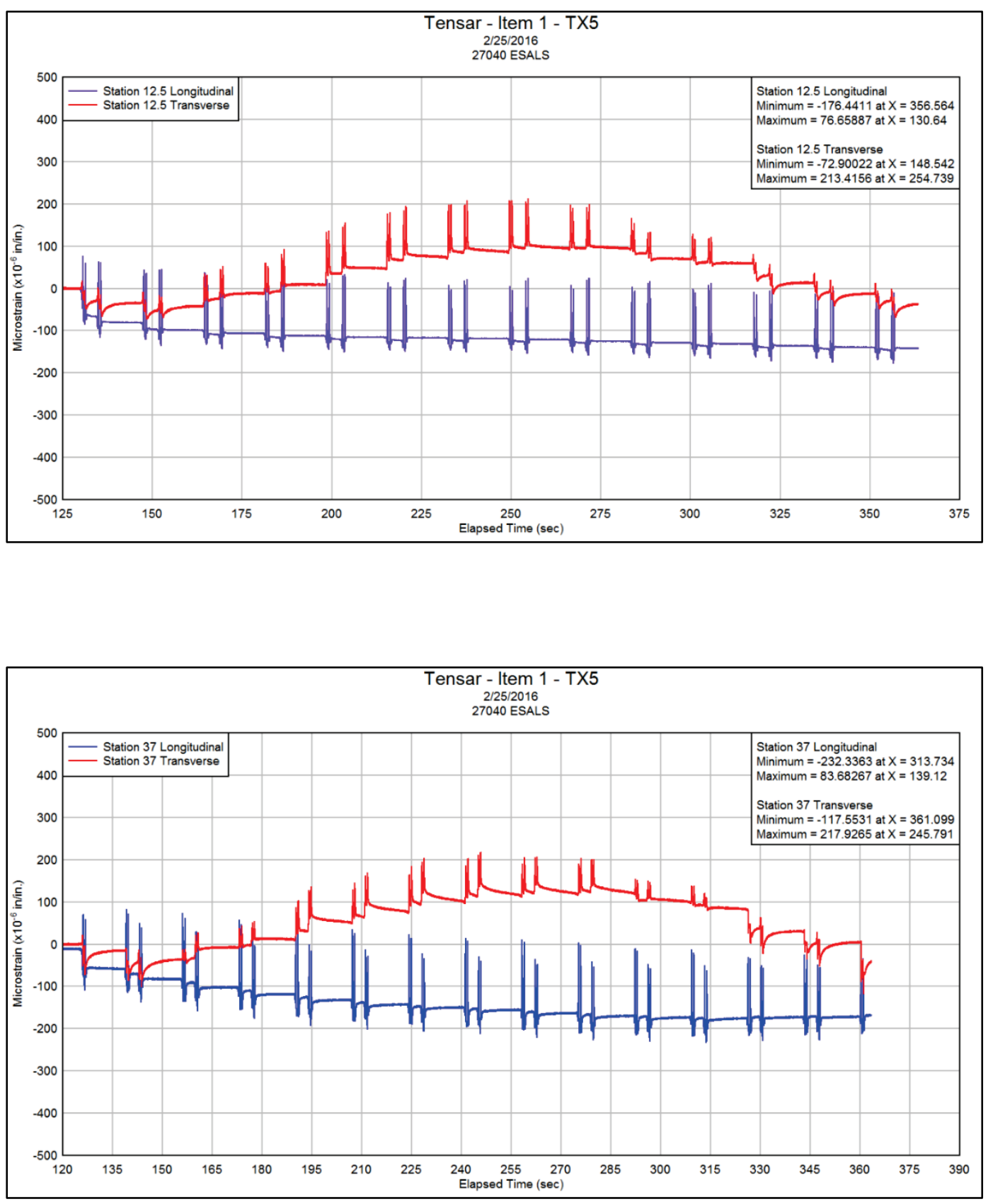

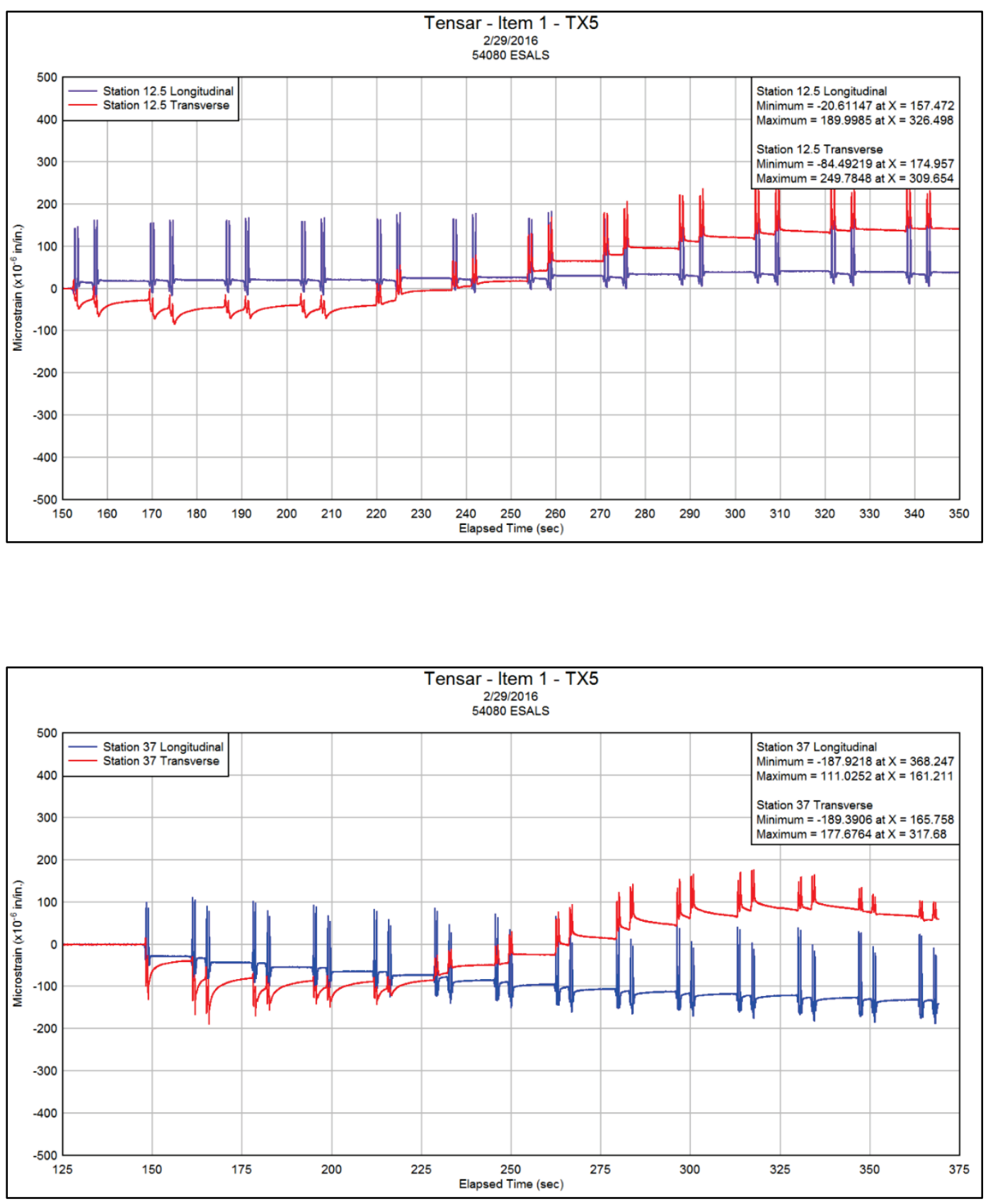

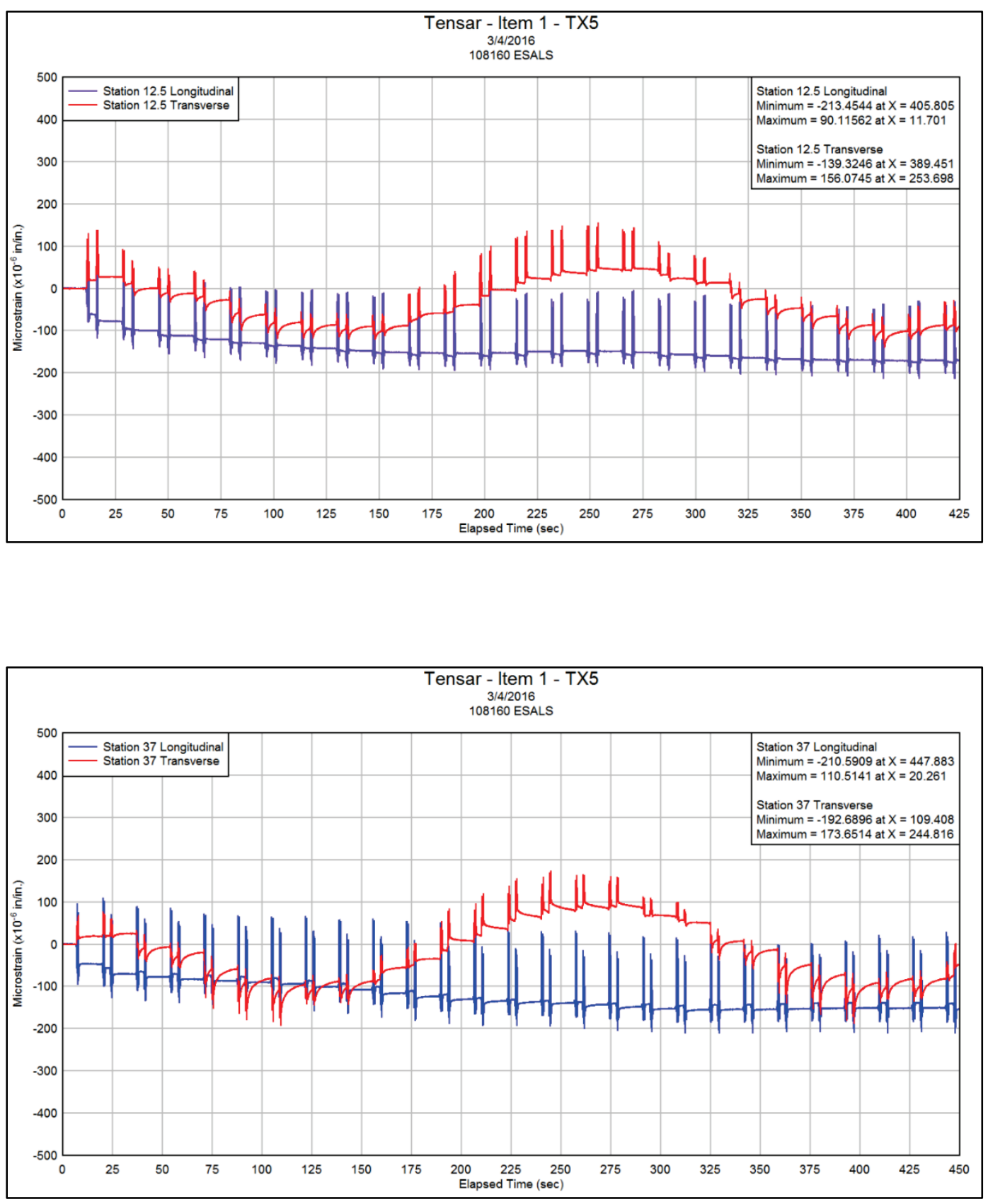

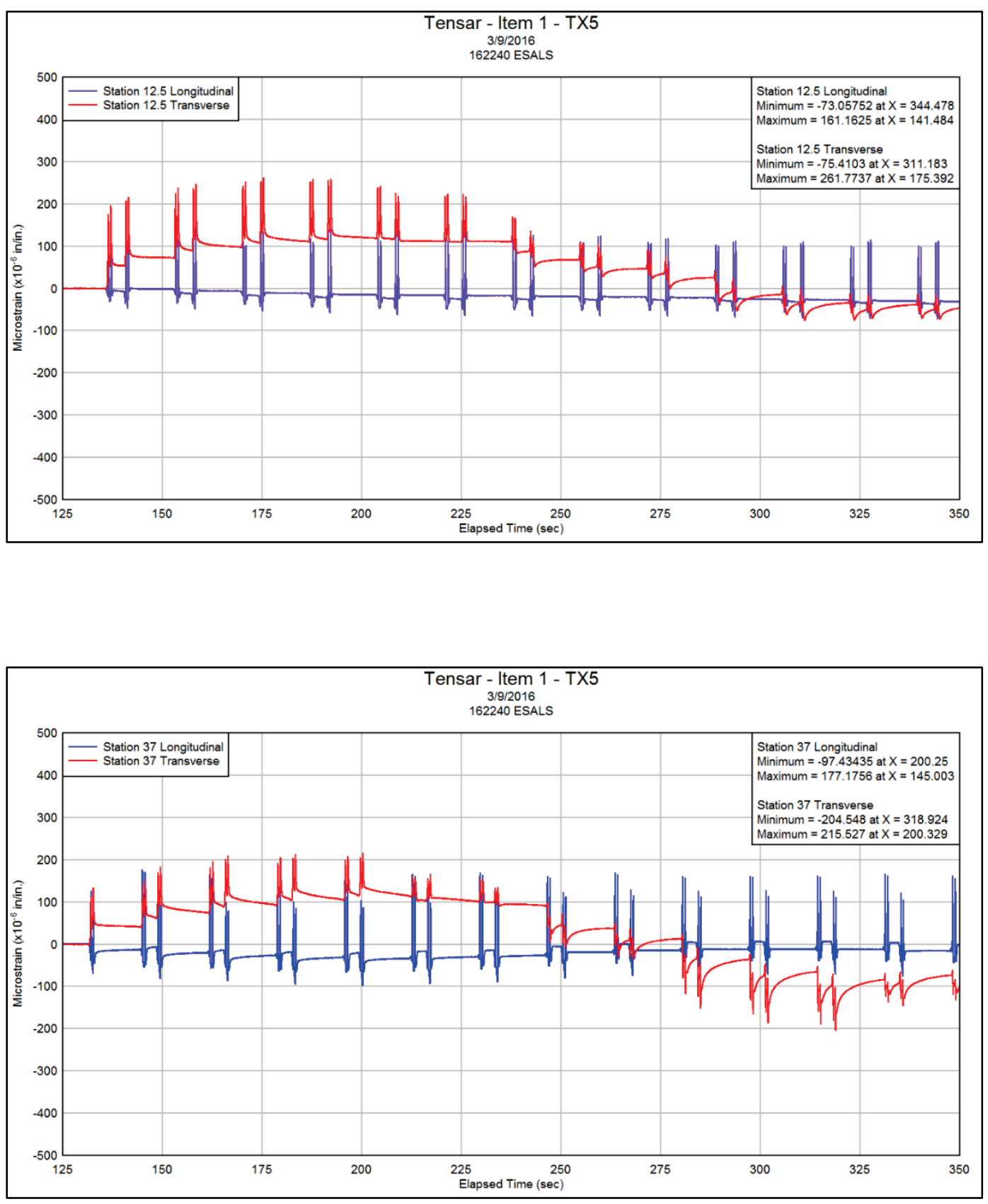

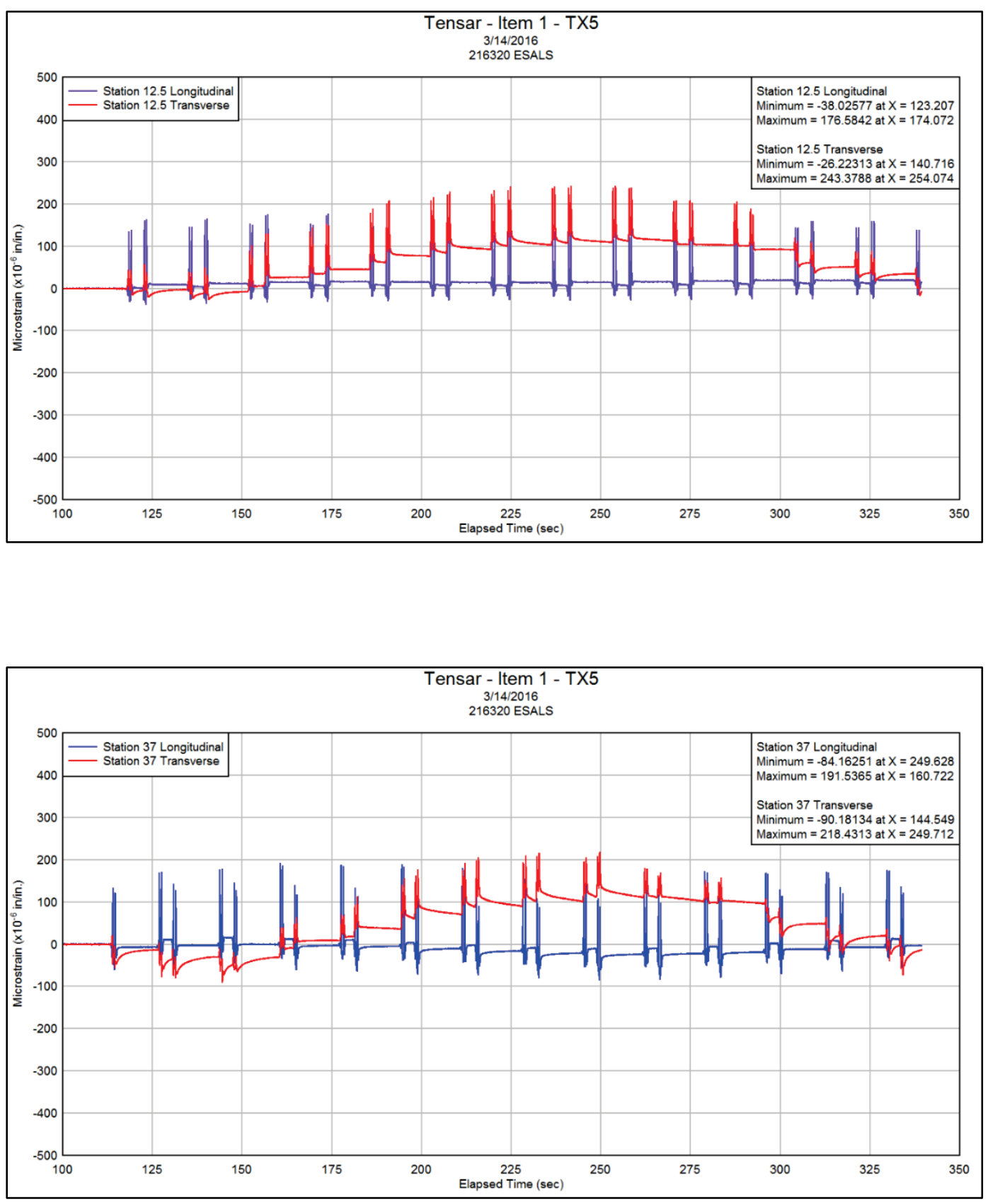

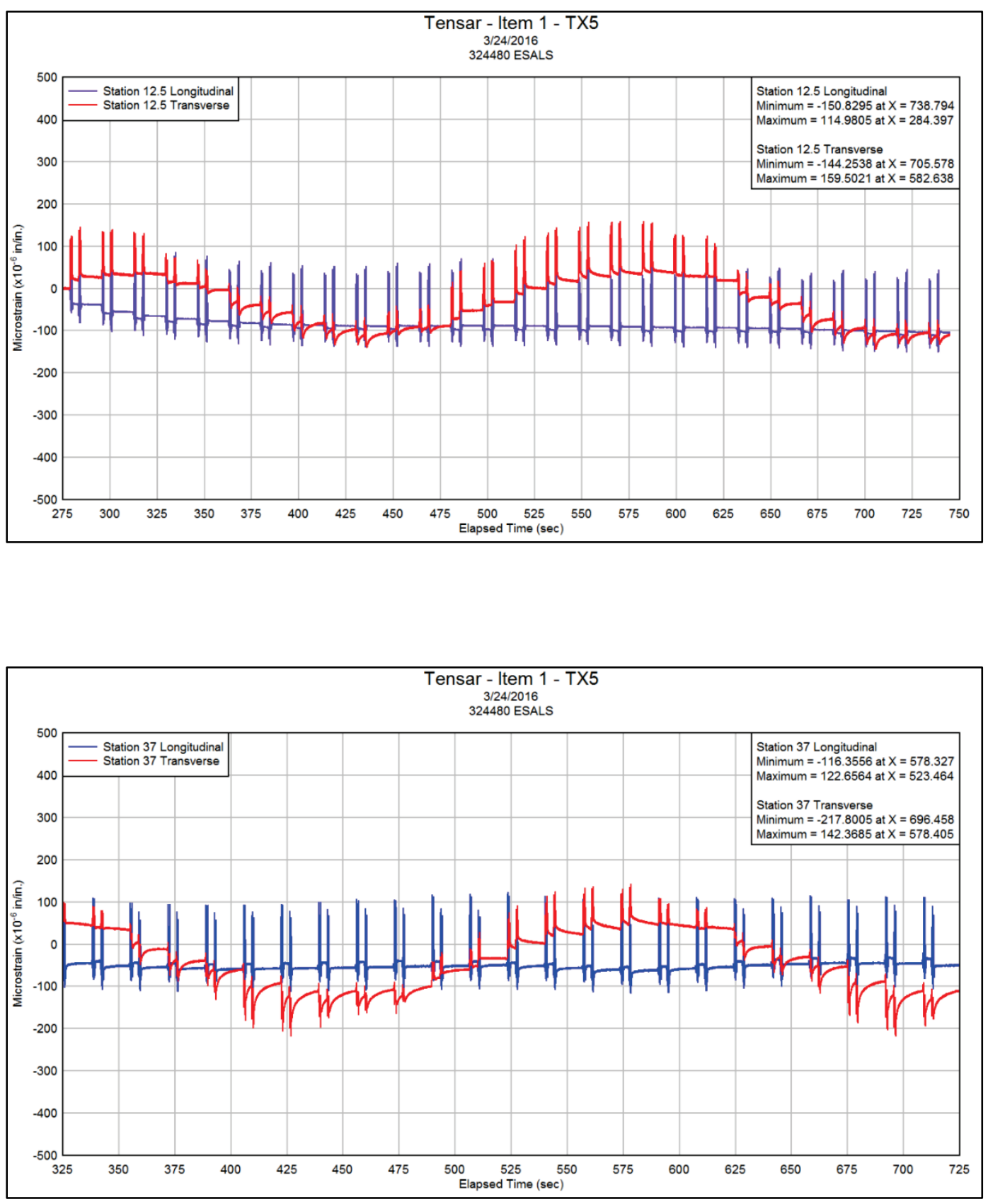

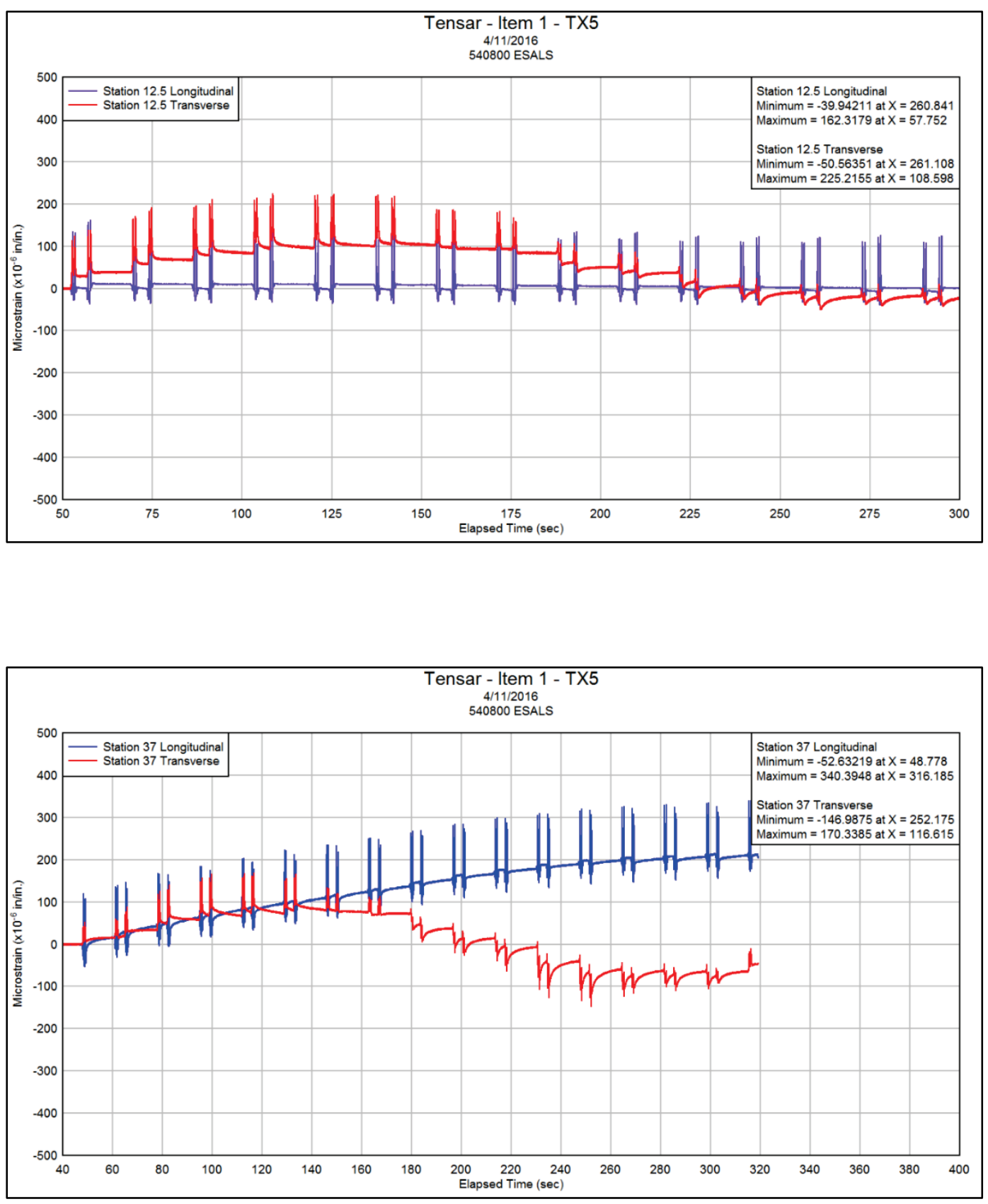

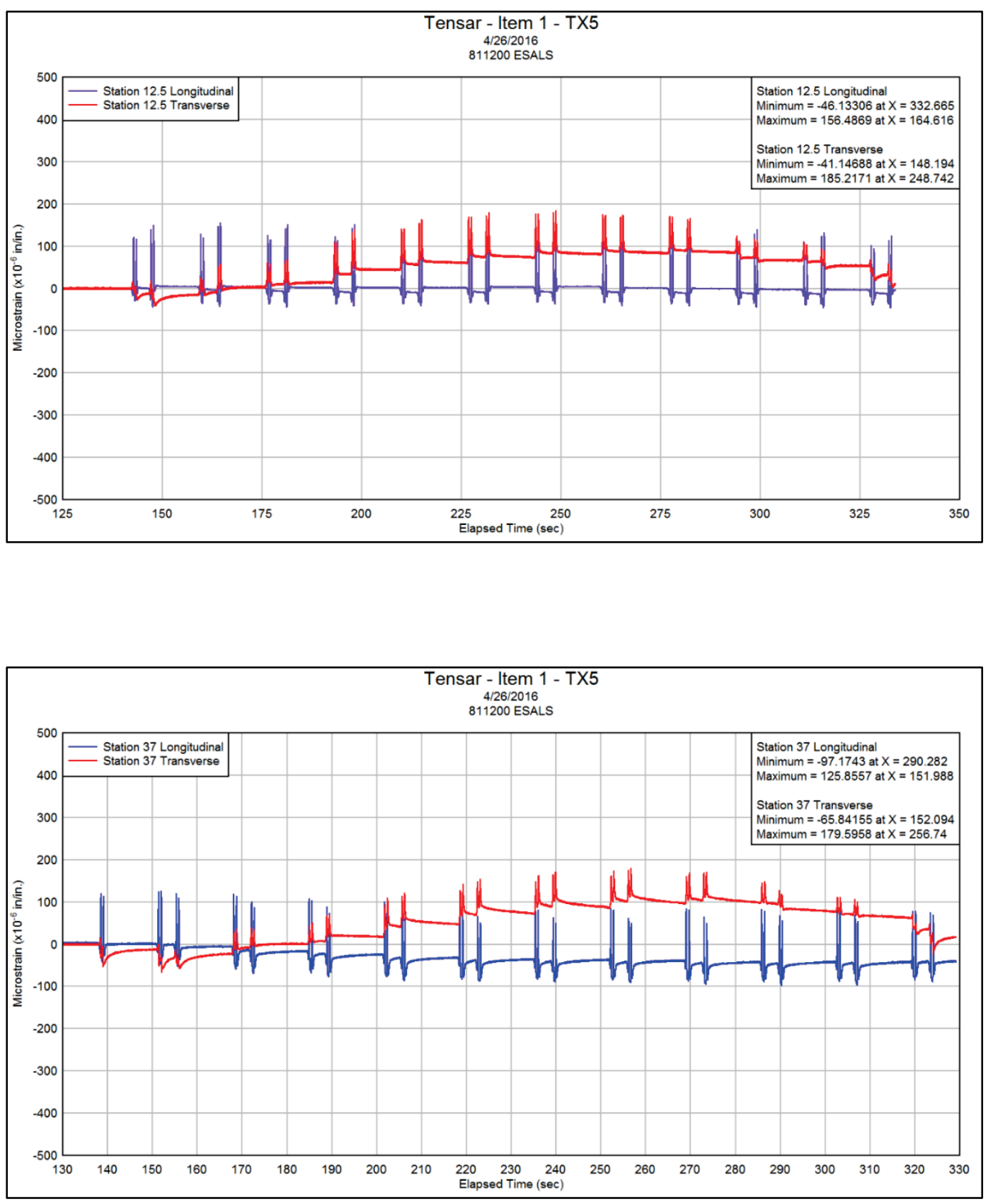

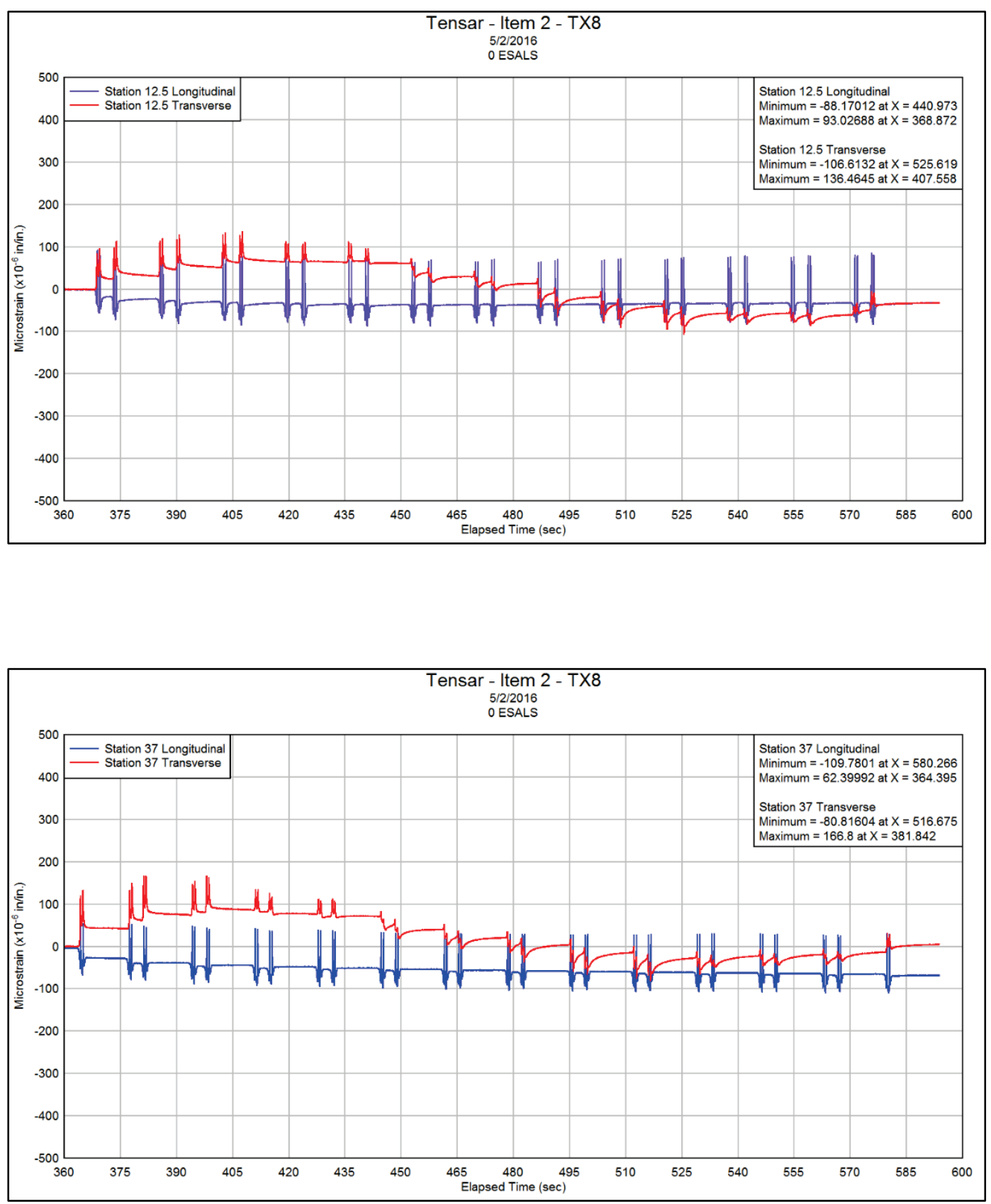

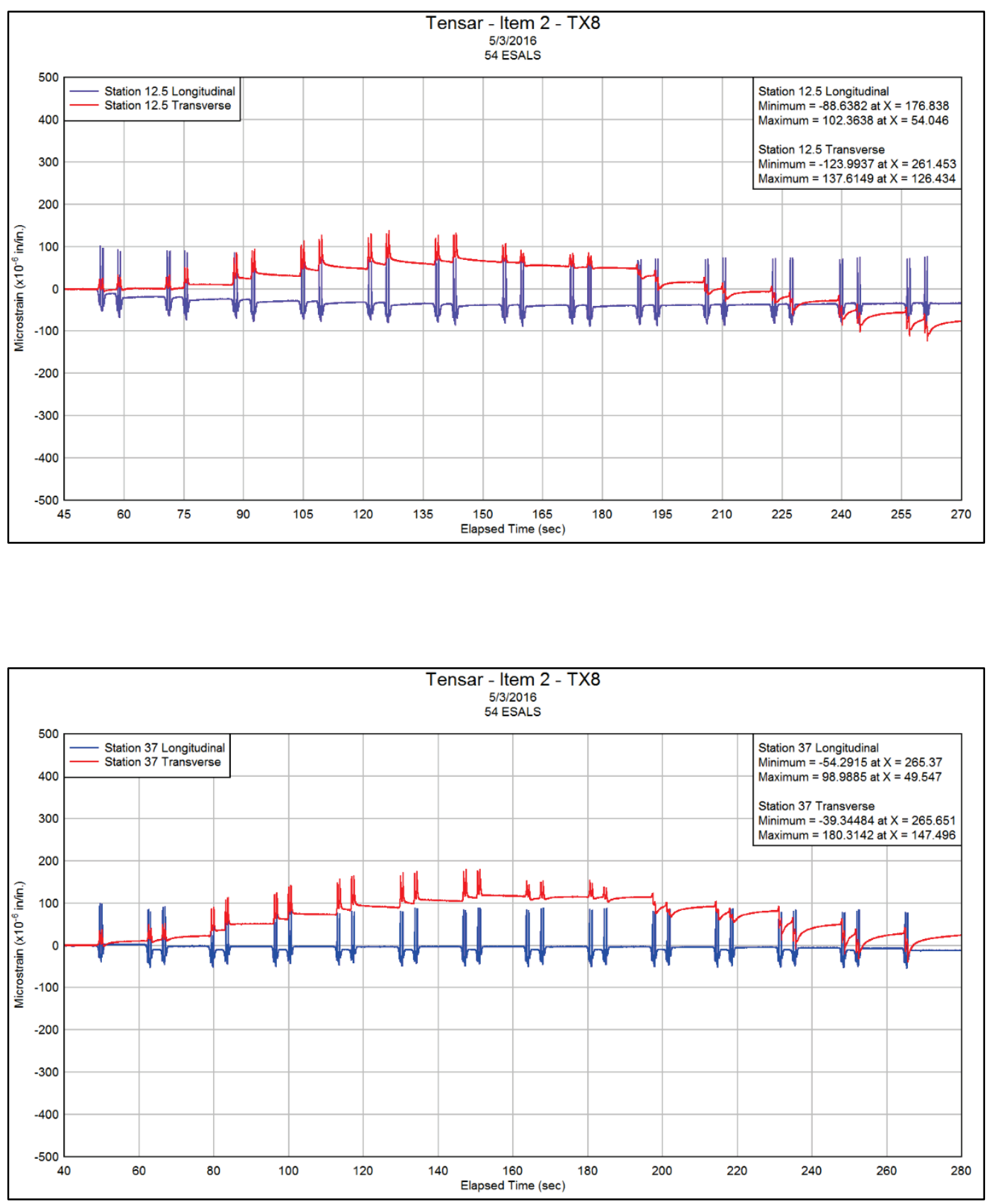

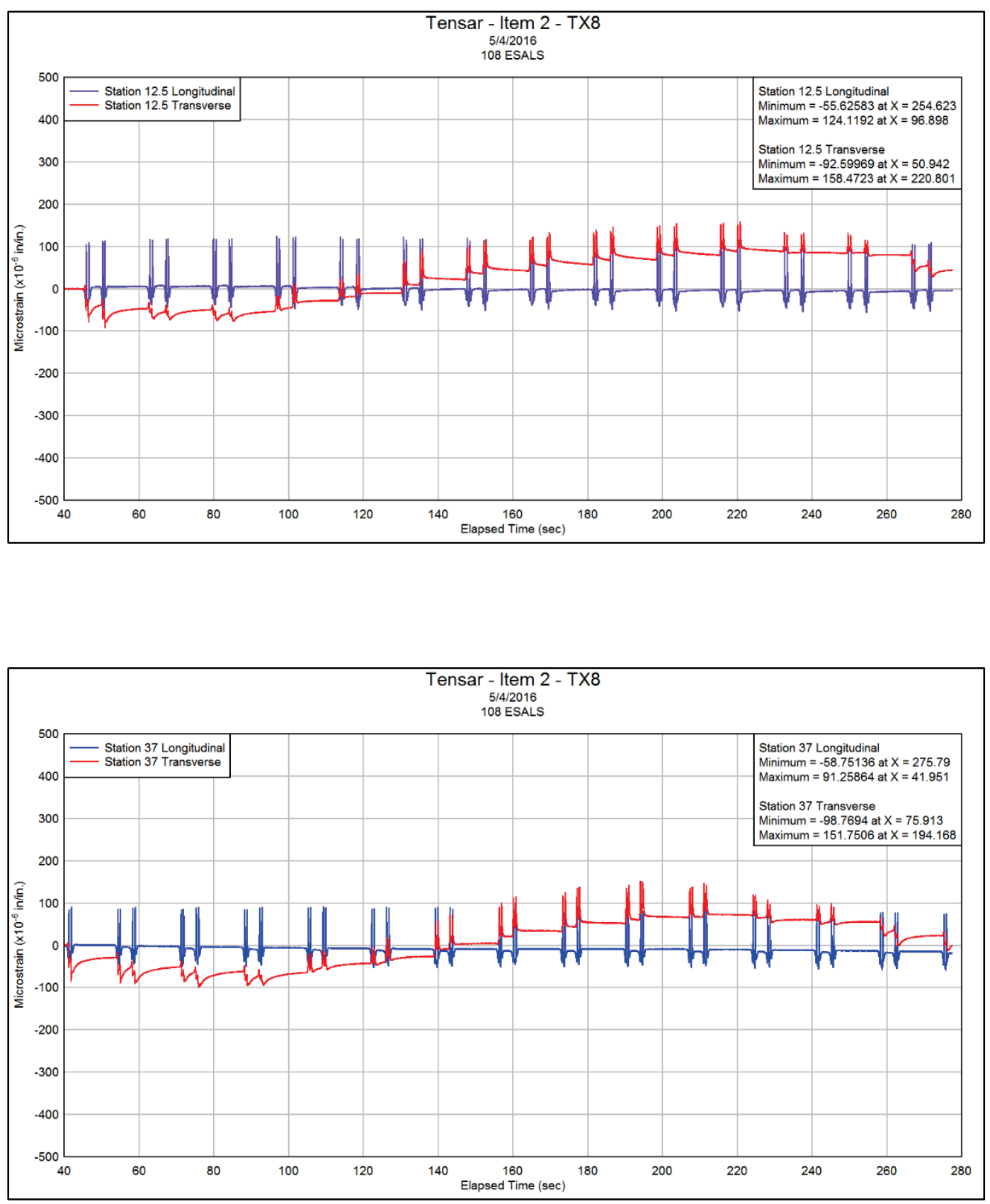

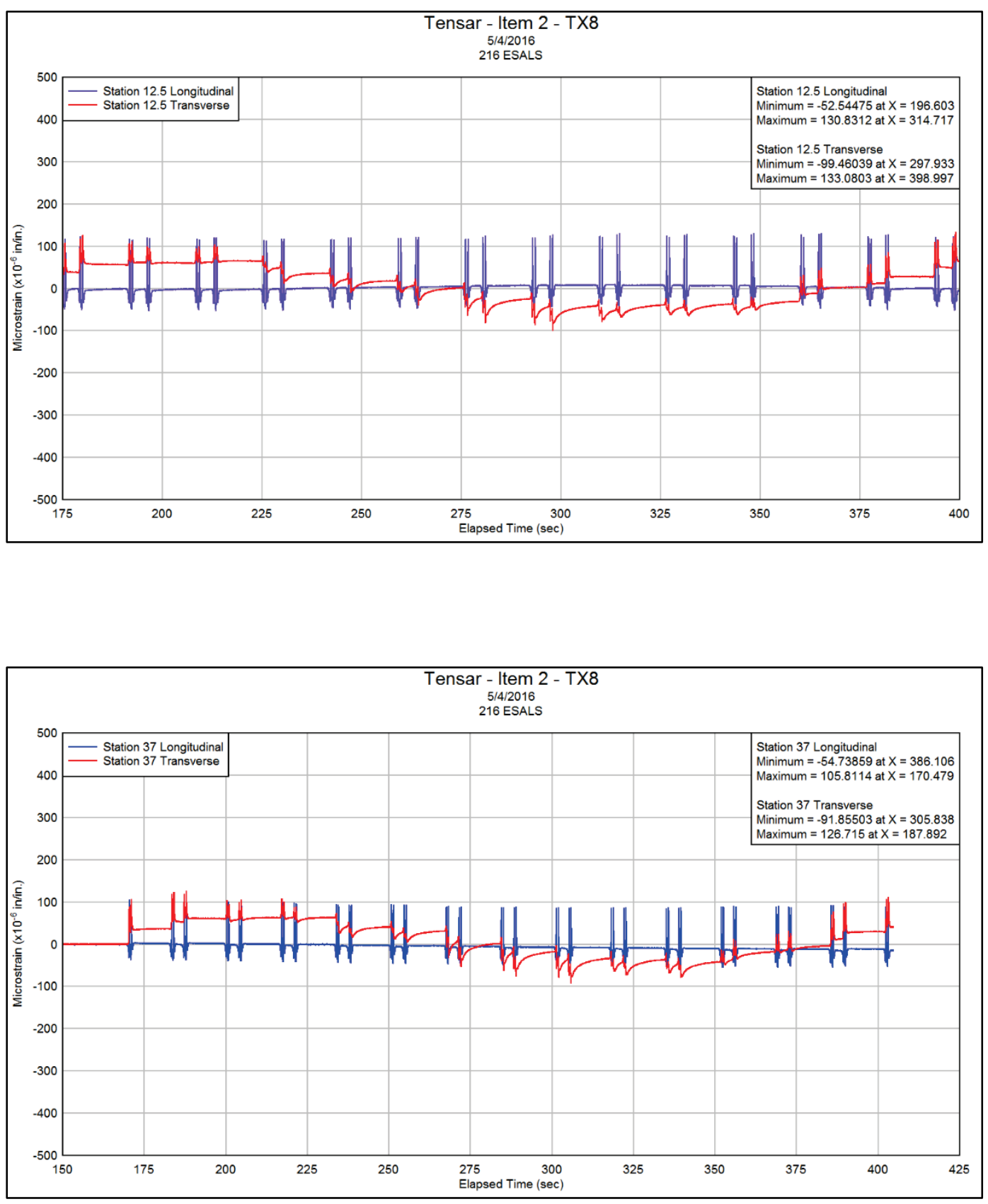

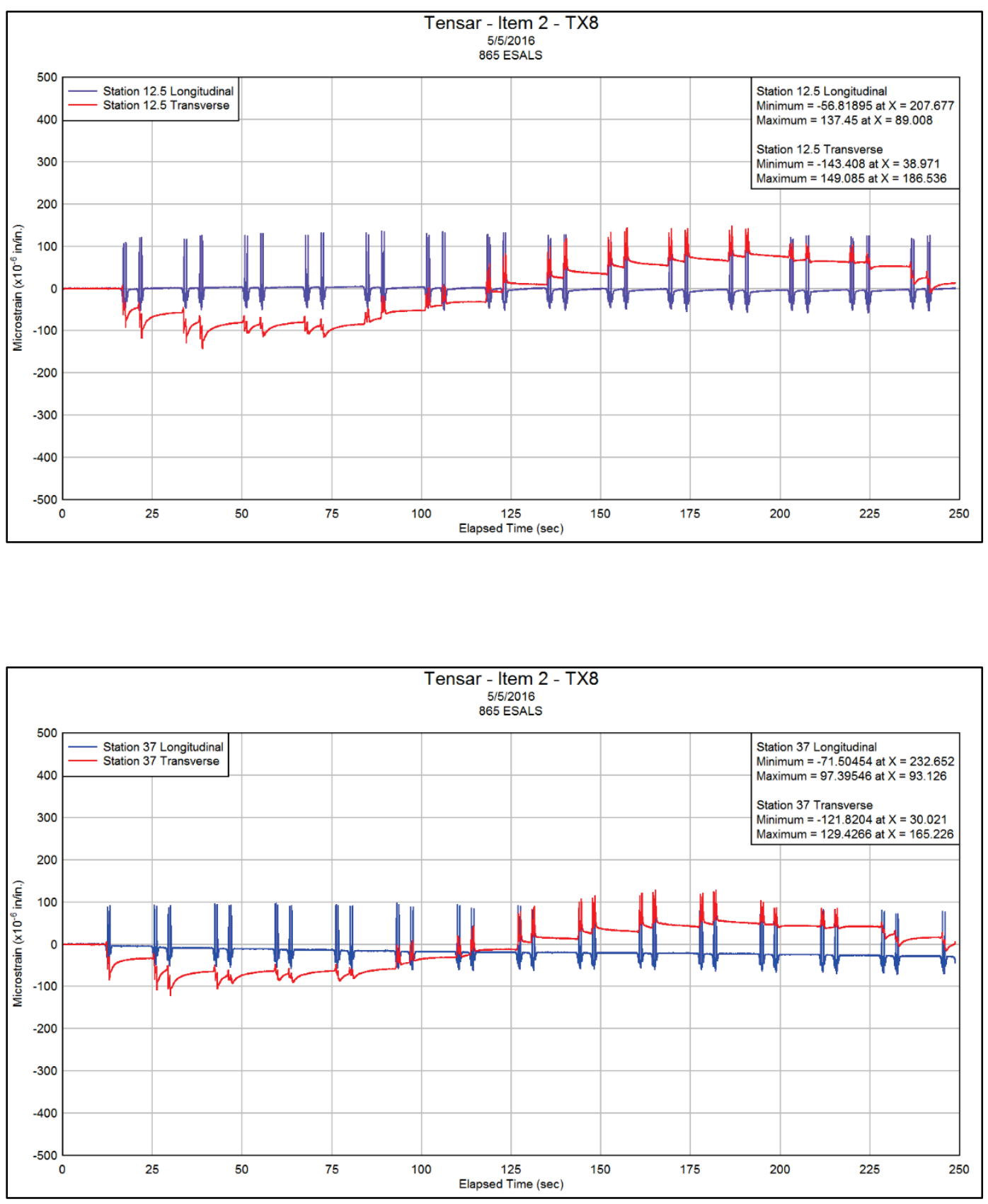

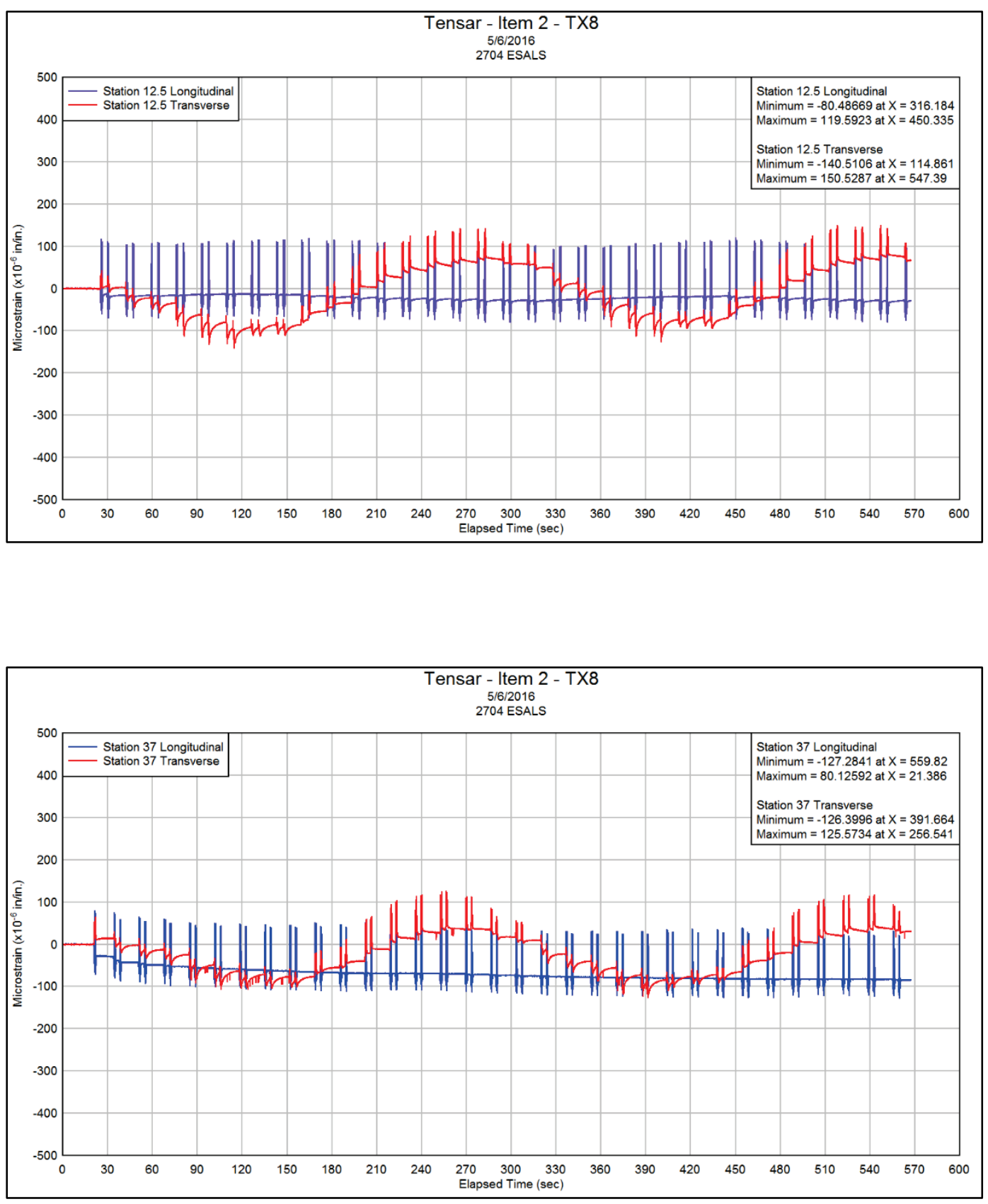

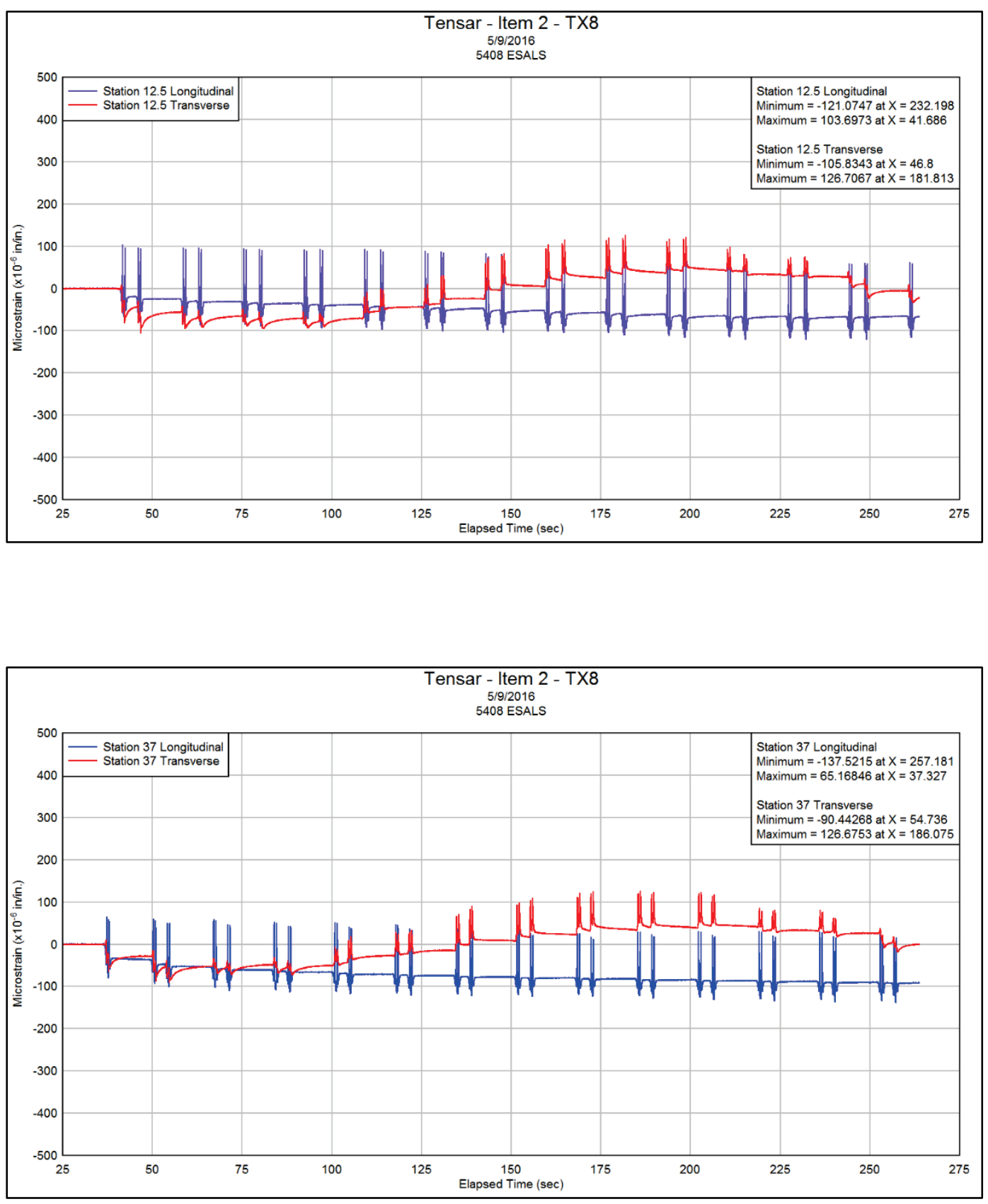

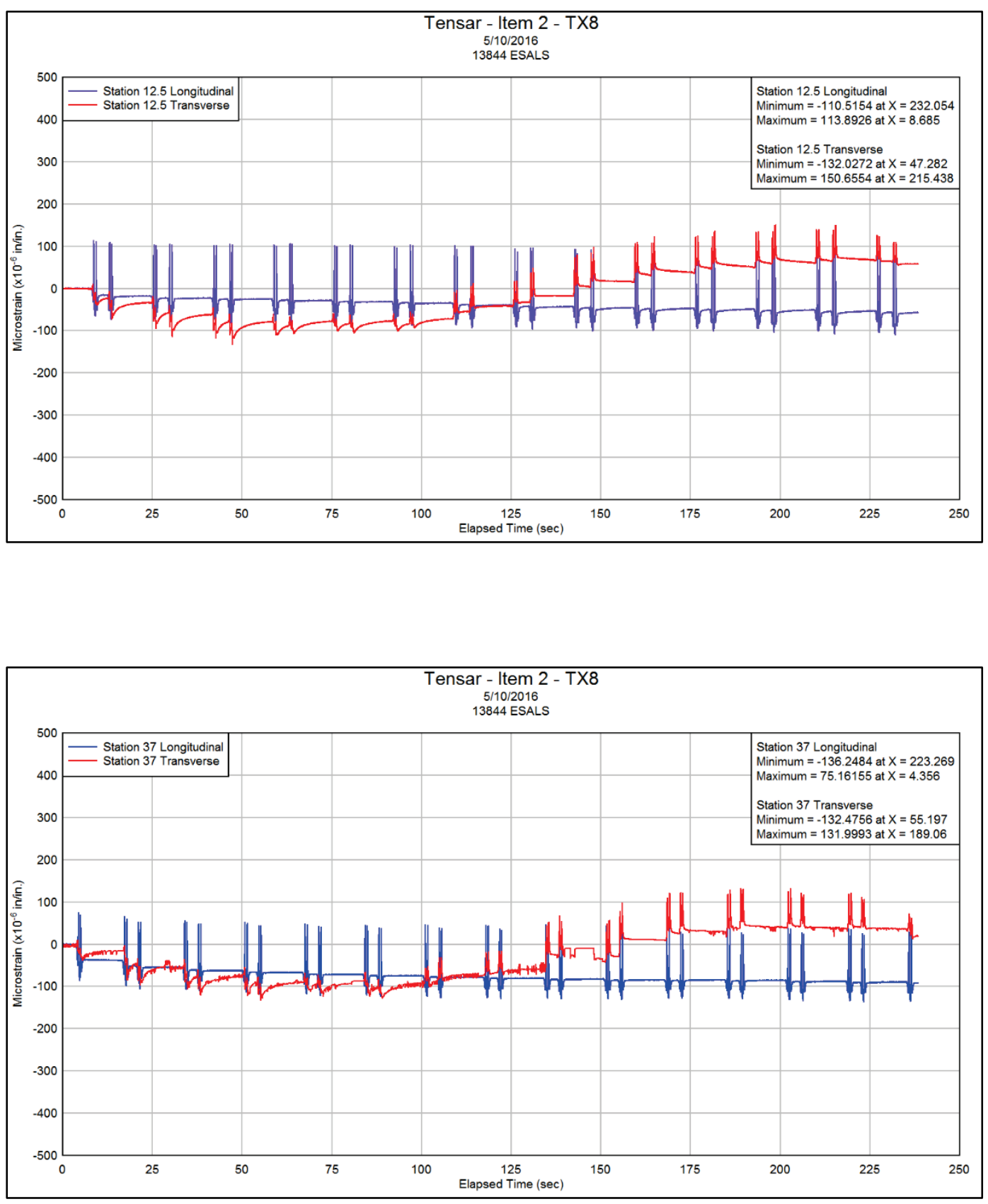

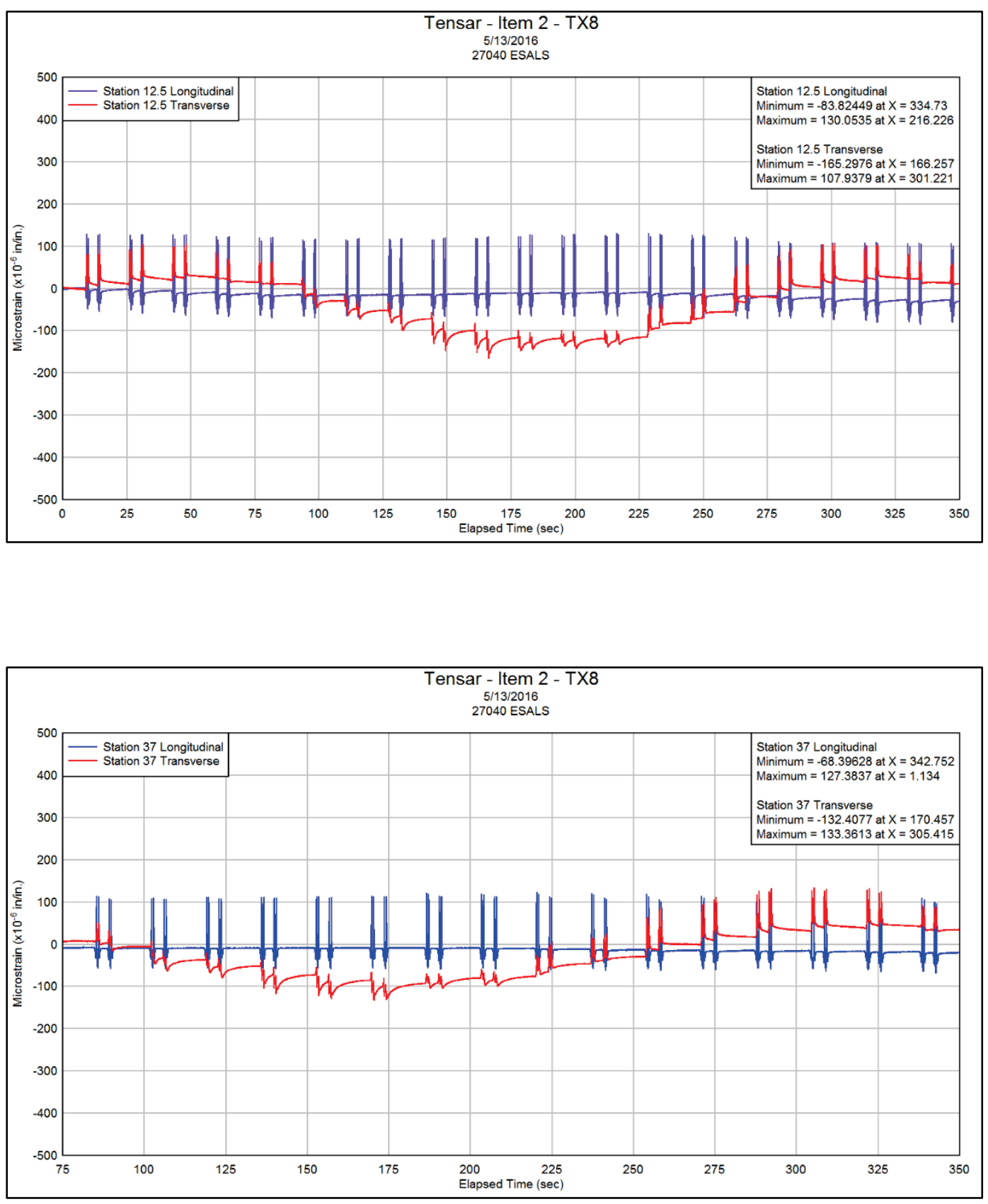

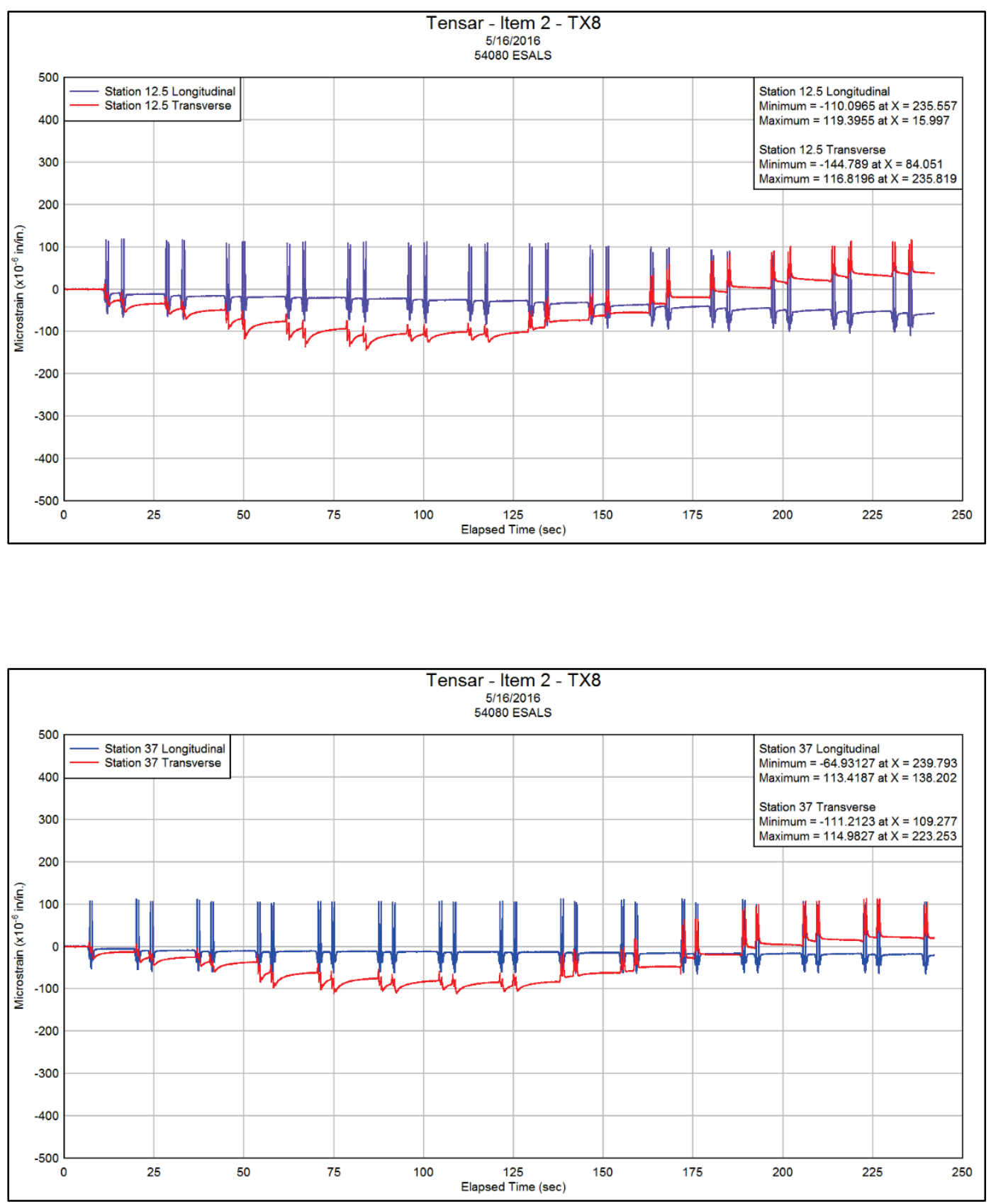

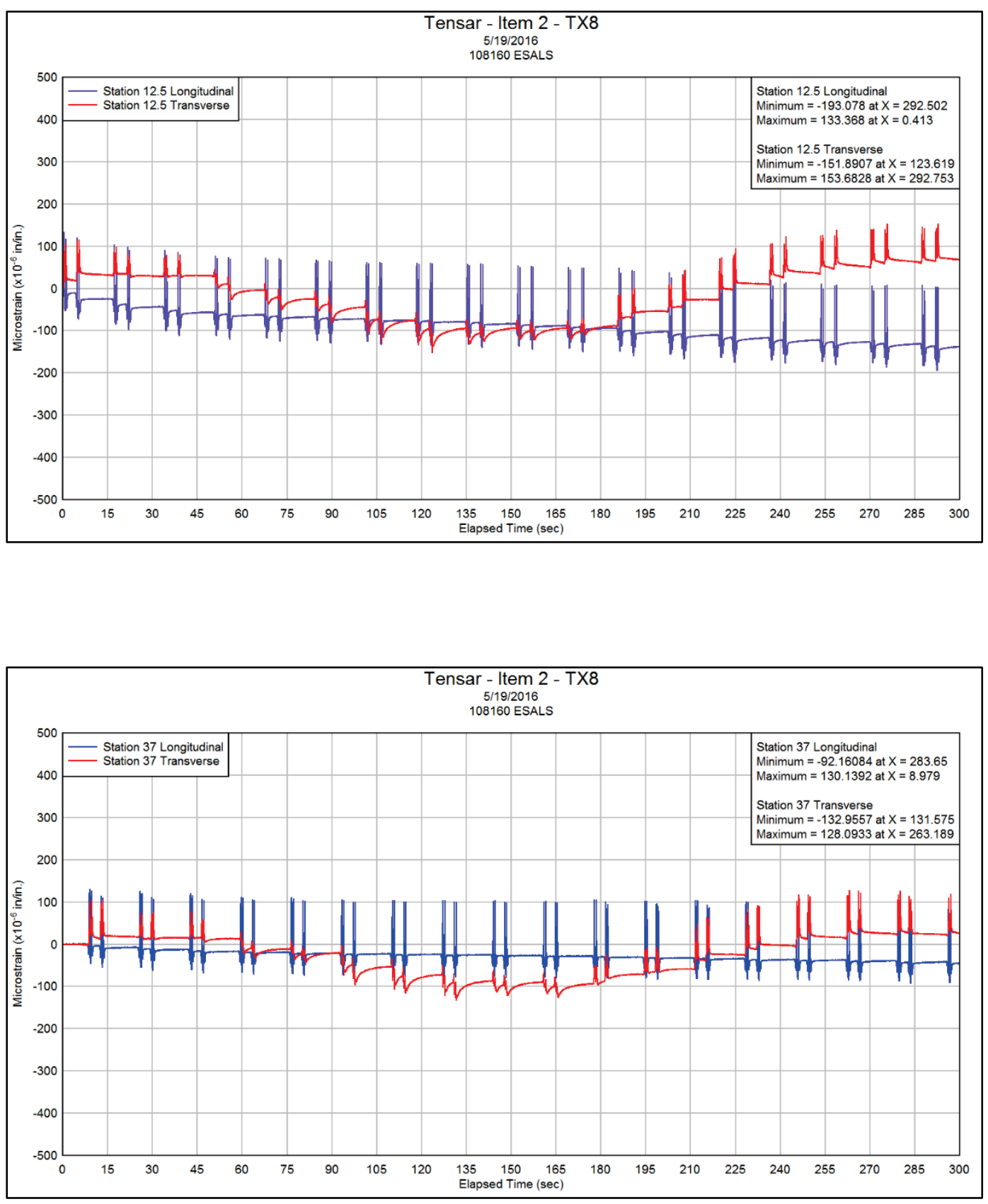

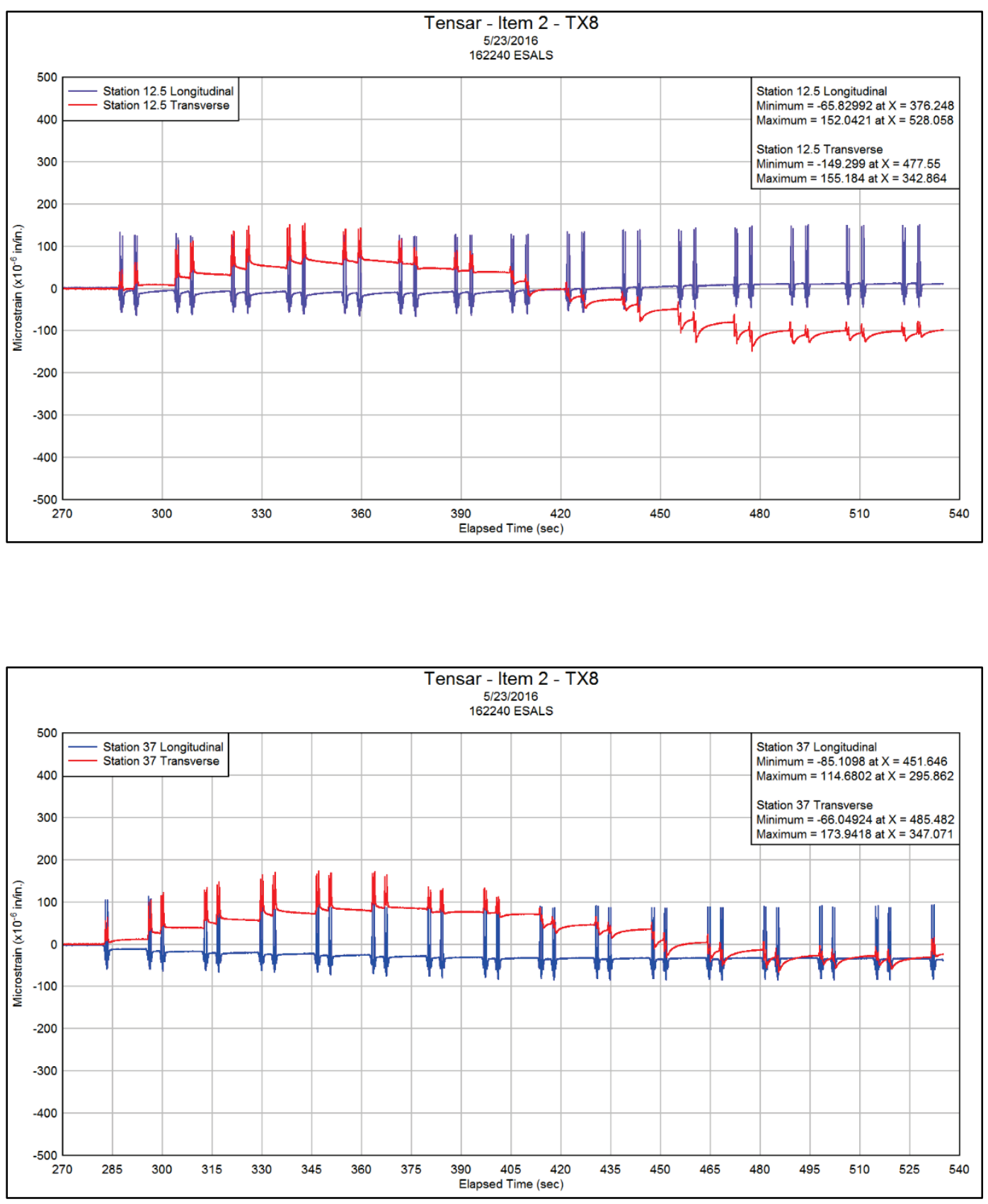

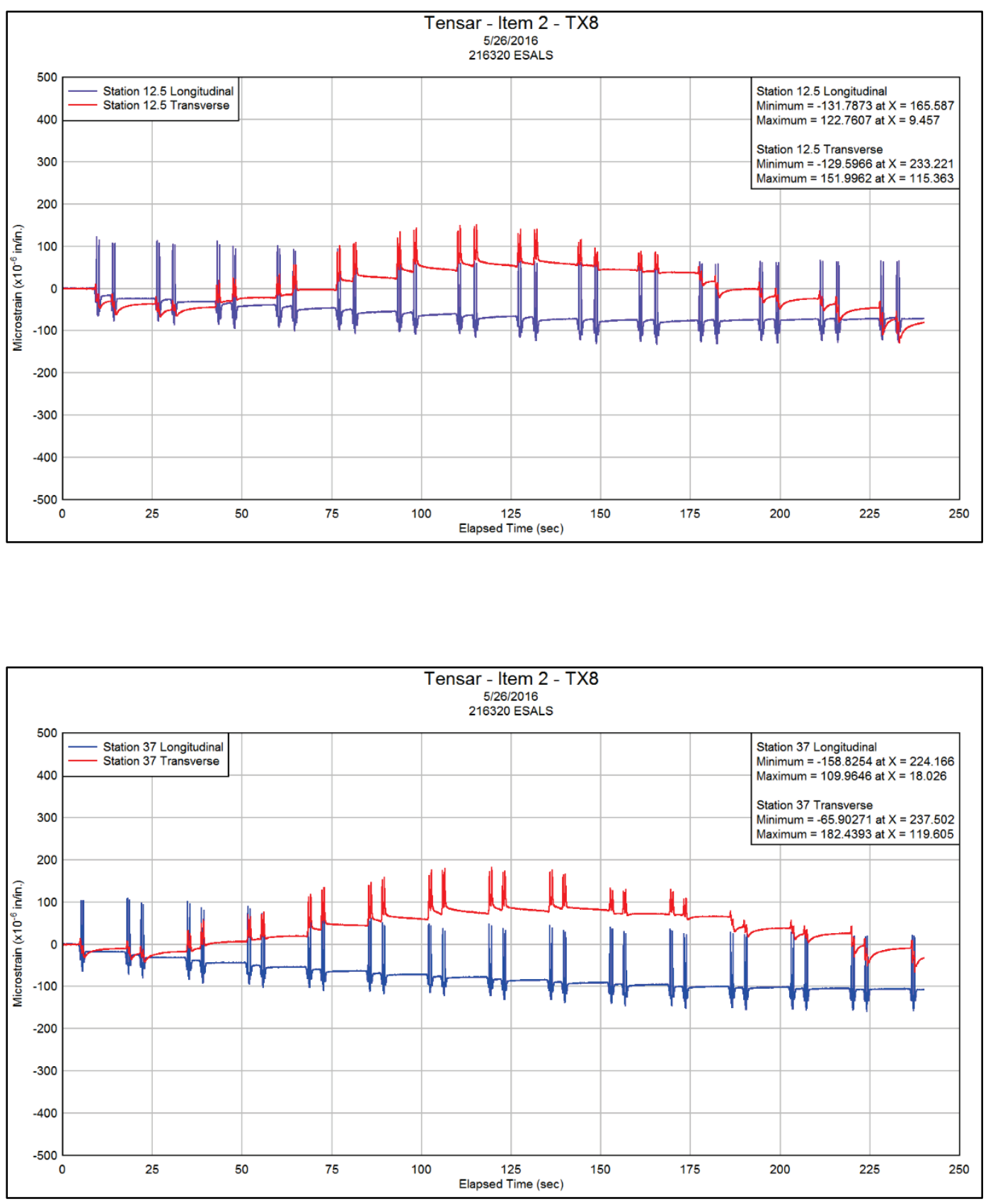

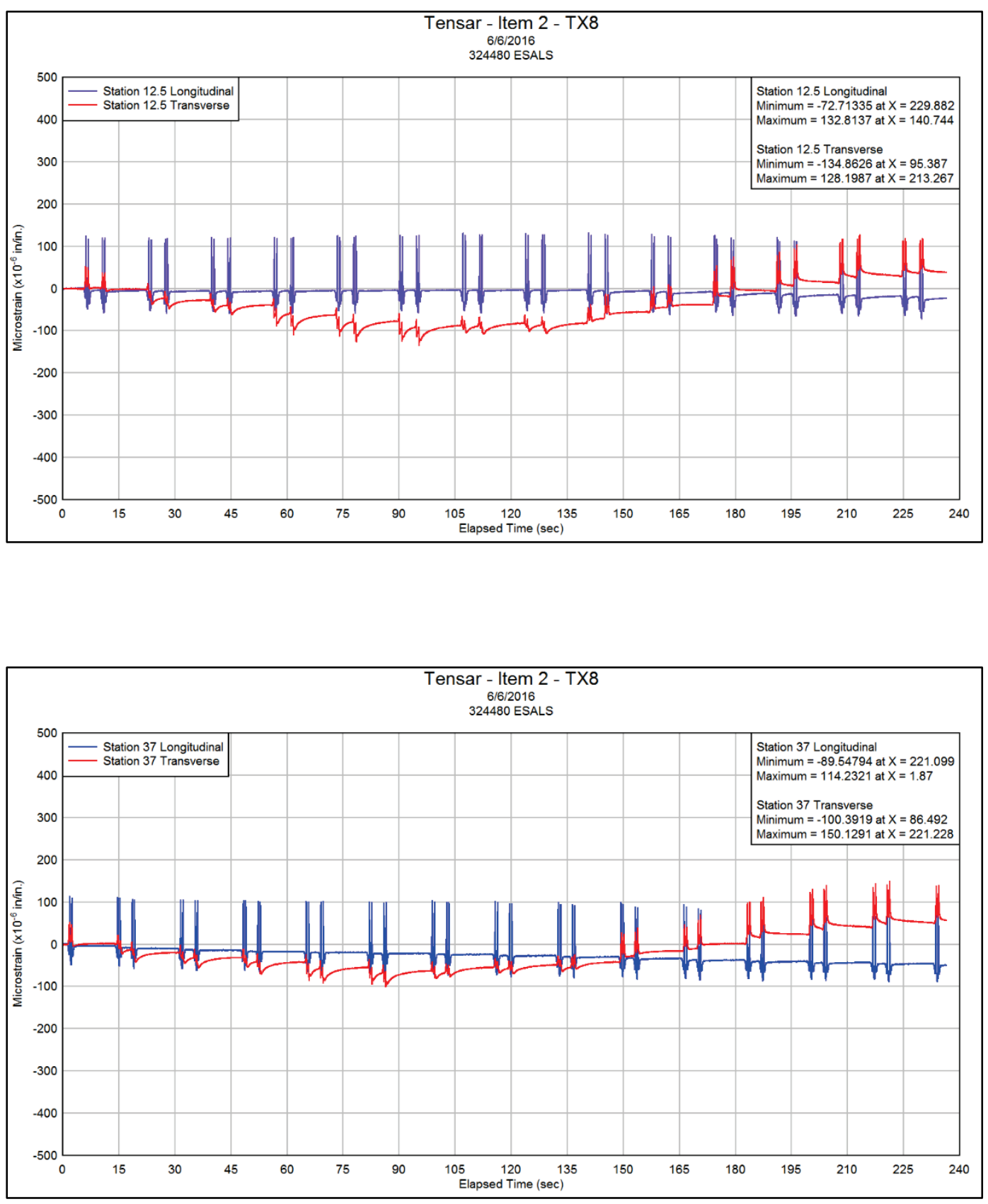

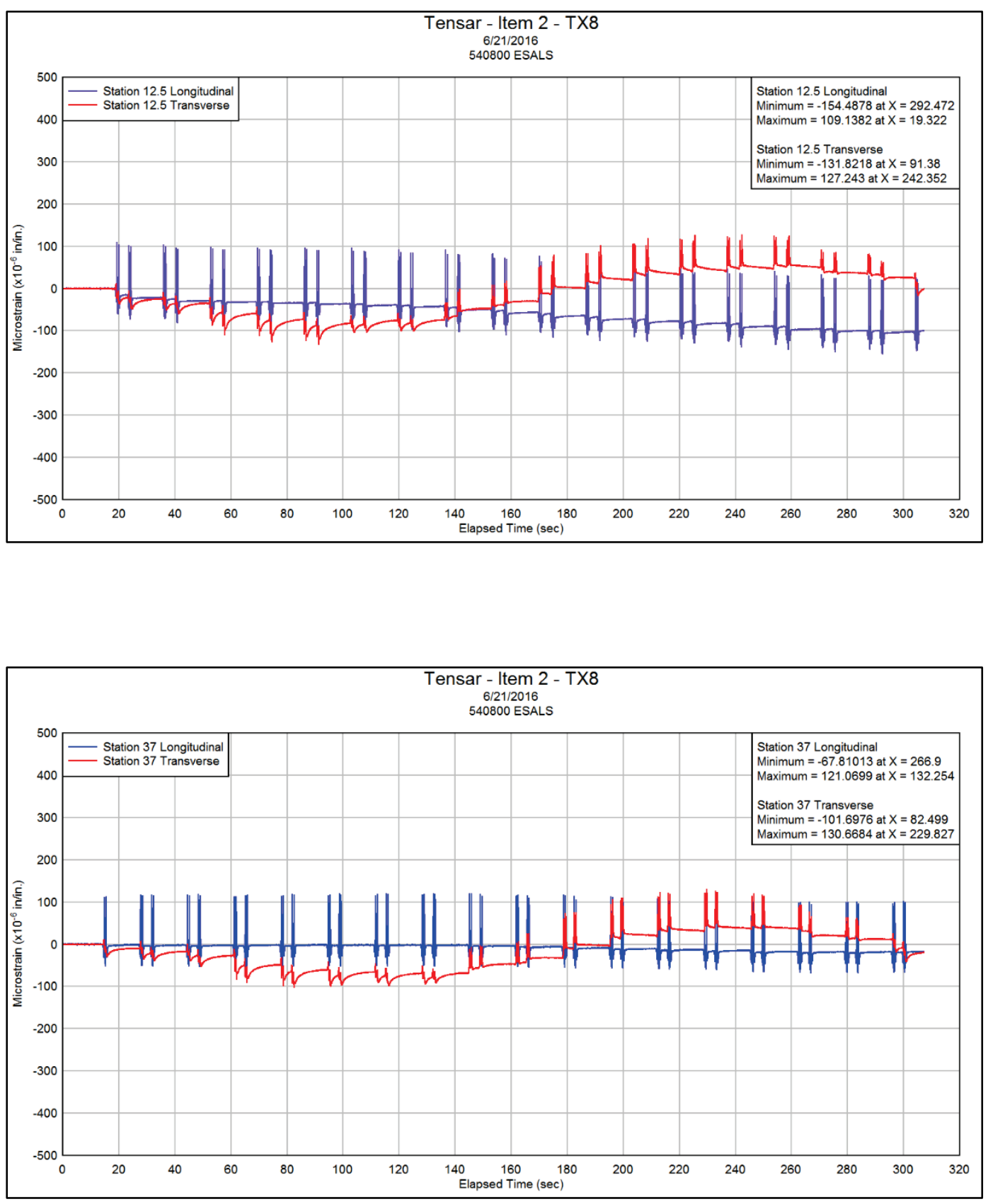

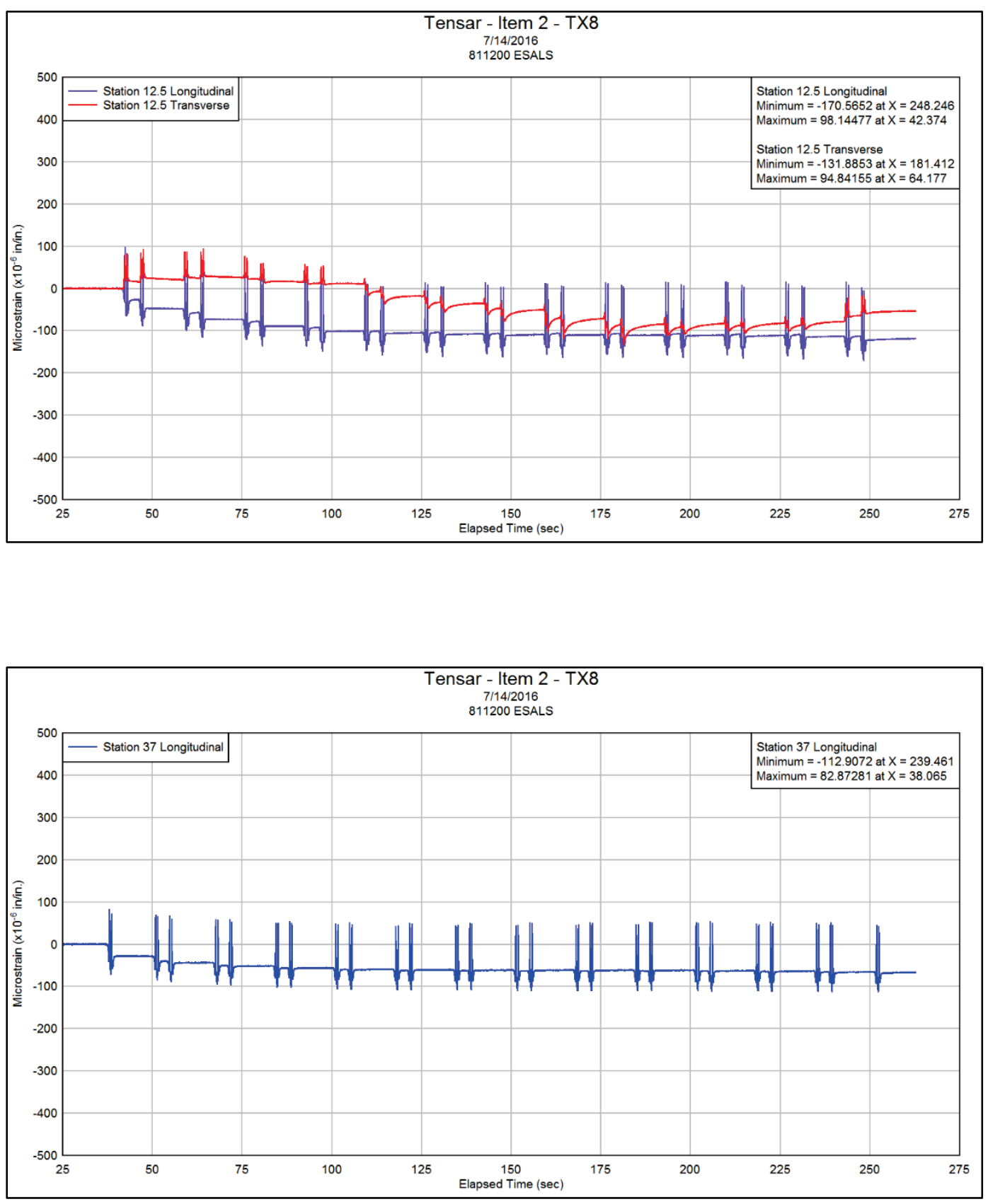


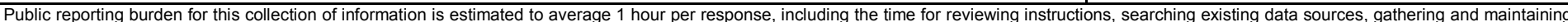

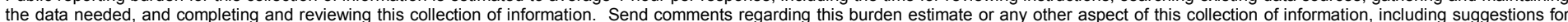

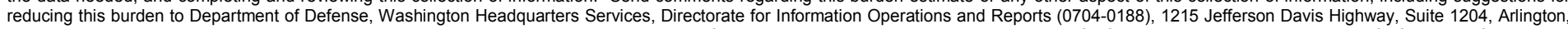

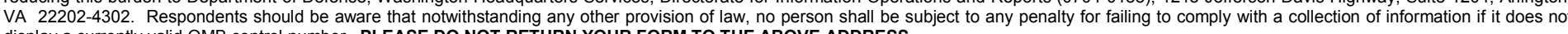
display a currently valid OMB control number. PLEASE DO NOT RETURN YOUR FORM TO THE ABOVE ADDRESS.
1. REPORT DATE (DD-MM-YYYY)
June 2017

\section{TITLE AND SUBTITLE}

Full-Scale Accelerated Testing of Multi-axial Geogrid Stabilized Flexible Pavements
3. DATES COVERED (From - To)

5a. CONTRACT NUMBER

5b. GRANT NUMBER

\section{AUTHOR(S)}

W. Jeremy Robinson, P.E., Jeb S. Tingle, and Gregory J. Norwood, P.E.

5d. PROJECT NUMBER

151098

5e. TASK NUMBER

5f. WORK UNIT NUMBER

8. PERFORMING ORGANIZATION REPORT NUMBER

ERDC/GSL TR-17-9

U.S. Army Engineer Research and Development Center

3909 Halls Ferry Road

Vicksburg, MS 39180-6199

\section{SPONSORING / MONITORING AGENCY NAME(S) AND ADDRESS(ES)}

Tensar International Corporation

Alpharetta, GA
10. SPONSOR/MONITOR'S ACRONYM(S)

11. SPONSOR/MONITOR'S REPORT NUMBER(S)

\section{DISTRIBUTION / AVAILABILITY STATEMENT}

Approved for public release; distribution is unlimited.

\section{SUPPLEMENTARY NOTES}

\section{ABSTRACT}

The U.S. Army Engineer Research and Development Center (ERDC) constructed a full-scale test section to evaluate the performance of geogrid-stabilized highway pavements. The test section consisted of two pavements composed of 3 in. of hot mix asphalt over a crushed limestone base course over a 6 CBR subgrade. One section was stabilized with Tensar's TX5 multi-axial geogrid, and the second section was stabilized with a developmental geogrid referred to as TX8. Each section was instrumented with moisture probes, pore-water pressure probes, temperature probes, earth pressure cells, and asphalt strain gauges. Simulated truck traffic was applied using a heavy vehicle simulator (HVS) to evaluate the rutting performance and collect instrumentation response data. This report summarizes the material characterization and construction techniques, instrumentation response, and performance response of each section under simulated truck traffic. Comparisons are drawn to previous sections constructed and trafficked at ERDC without geogrids utilizing similar construction techniques and material properties.

\begin{tabular}{|c|c|c|c|c|c|}
\hline \multicolumn{2}{|c|}{ 15. SUBJECT TERMS } & \multicolumn{2}{|c|}{ Pavements - Testing } & \multicolumn{2}{|c|}{ Geogrids } \\
\hline \multicolumn{2}{|c|}{ Geogrid } & \multicolumn{2}{|c|}{ Effective structural coefficient } & \multicolumn{2}{|c|}{ Soil stabilization } \\
\hline \multicolumn{2}{|c|}{ Base stabilization } & \multicolumn{4}{|c|}{ Pavements, Flexible } \\
\hline \multicolumn{2}{|c|}{ Pavements - Performance } & \multicolumn{4}{|c|}{ Heavy vehicle simulator } \\
\hline \multicolumn{3}{|c|}{ 16. SECURITY CLASSIFICATION OF: } & $\begin{array}{l}\text { 17. LIMITATION } \\
\text { OF ABSTRACT }\end{array}$ & $\begin{array}{l}\text { 18. NUMBER } \\
\text { OF PAGES }\end{array}$ & $\begin{array}{l}\text { 19a. NAME OF RESPONSIBLE } \\
\text { PERSON }\end{array}$ \\
\hline $\begin{array}{l}\text { a. REPORT } \\
\text { Unclassified }\end{array}$ & $\begin{array}{l}\text { b. ABSTRACT } \\
\text { Unclassified }\end{array}$ & $\begin{array}{l}\text { c. THIS PAGE } \\
\text { Unclassified }\end{array}$ & & 113 & $\begin{array}{l}\text { 19b. TELEPHONE NUMBER (include } \\
\text { area code) }\end{array}$ \\
\hline
\end{tabular}

